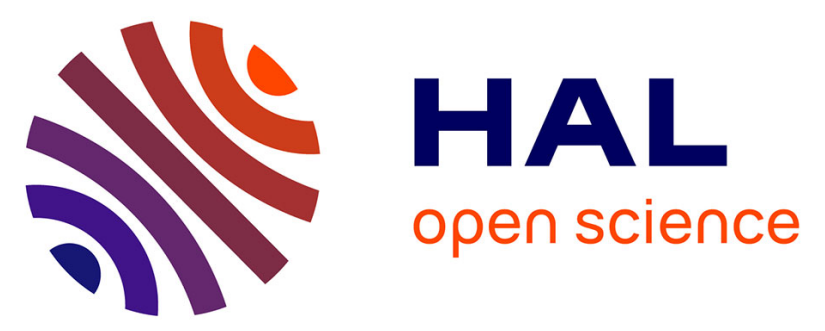

\title{
Sedimentary evolution and effects of structural controls on the development of the Zambezi mixed turbidite-contourite system (Mozambique channel, southwest Indian Ocean) since the Oligocene
}

\author{
Ruth Fierens, L. Droz, Gwenael Jouet, M. Rabineau, F. Raisson, N.
}

Babonneau, Cécile Robin, S.J. J Jorry

\section{To cite this version:}

Ruth Fierens, L. Droz, Gwenael Jouet, M. Rabineau, F. Raisson, et al.. Sedimentary evolution and effects of structural controls on the development of the Zambezi mixed turbidite-contourite system (Mozambique channel, southwest Indian Ocean) since the Oligocene. Marine and Petroleum Geology, 2022, 138, pp.105532. 10.1016/j.marpetgeo.2022.105532 . insu-03522796

\section{HAL Id: insu-03522796 \\ https://hal-insu.archives-ouvertes.fr/insu-03522796}

Submitted on 12 Jan 2022

HAL is a multi-disciplinary open access archive for the deposit and dissemination of scientific research documents, whether they are published or not. The documents may come from teaching and research institutions in France or abroad, or from public or private research centers.
L'archive ouverte pluridisciplinaire HAL, est destinée au dépôt et à la diffusion de documents scientifiques de niveau recherche, publiés ou non, émanant des établissements d'enseignement et de recherche français ou étrangers, des laboratoires publics ou privés. 


\section{Journal Pre-proof}

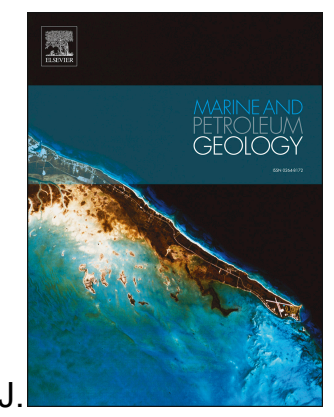

Sedimentary evolution and effects of structural controls on the development of the Zambezi mixed turbidite-contourite system (Mozambique channel, southwest Indian Ocean) since the Oligocene

R. Fierens, L. Droz, G. Jouet, M. Rabineau, F. Raisson, N. Babonneau, C. Robin, S.J. Jorry

PII: S0264-8172(22)00010-1

DOI: https://doi.org/10.1016/j.marpetgeo.2022.105532

Reference: JMPG 105532

To appear in: $\quad$ Marine and Petroleum Geology

Received Date: 6 September 2021

Revised Date: 24 December 2021

Accepted Date: 3 January 2022

Please cite this article as: Fierens, R., Droz, L., Jouet, G., Rabineau, M., Raisson, F., Babonneau, N., Robin, C., Jorry, S.J., Sedimentary evolution and effects of structural controls on the development of the Zambezi mixed turbidite-contourite system (Mozambique channel, southwest Indian Ocean) since the Oligocene, Marine and Petroleum Geology (2022), doi: https://doi.org/10.1016/ j.marpetgeo.2022.105532.

This is a PDF file of an article that has undergone enhancements after acceptance, such as the addition of a cover page and metadata, and formatting for readability, but it is not yet the definitive version of record. This version will undergo additional copyediting, typesetting and review before it is published in its final form, but we are providing this version to give early visibility of the article. Please note that, during the production process, errors may be discovered which could affect the content, and all legal disclaimers that apply to the journal pertain.

(C) 2022 Published by Elsevier Ltd. 


\title{
Sedimentary evolution and effects of structural controls on the development of the
} Zambezi mixed turbidite-contourite system (Mozambique Channel, Southwest Indian Ocean) since the Oligocene

\author{
R. Fierens ${ }^{1 *}$, L. Droz¹, G. Jouet ${ }^{2}$, M. Rabineau ${ }^{1}$, F. Raisson ${ }^{3}$,
}

N. Babonneau ${ }^{4}$, C. Robin ${ }^{5}$, S.J. Jorry ${ }^{2}$

1: CNRS, Université Bretagne Occidentale, Ifremer, Geo-Ocean, UMR6538, IUEM, 29280, Plouzané, France

2: Ifremer, Université Bretagne Occidentale, CNRS, Geo-Ocean, 29280, Plouzané, France

3: Clastic Sedimentology Group, TotalEnergies, 64000 Pau, France

4: Université Bretagne Occidentale, CNRS, Ifremer, Geo-Ocean, UMR6538, IUEM, 29280, Plouzané, France

5: CNRS, Géosciences Rennes, UMR6118, Université de Rennes, Rennes, 35042, France *Corresponding author: ruth.fierens@univ-brest.fr

\section{ABSTRACT}

High-resolution multichannel seismic reflection data that spans significant parts of the Mozambique margin offshore the Zambezi River permits the study of the Oligocene to present architectural evolution of the Zambezi turbidite system. In this time frame, five major depositional units are recognized that evidence a widespread spatial and temporal occurrence of both turbiditic and contouritic sedimentation. They indicate that the sedimentary regime within the turbidite system changed from dominantly aggradational during the Oligocene to mainly erosional during Miocene to an interplay of erosional and depositional processes during the Plio-Quaternary. Different episodes of incision, linked with the Serpa Pinto, Angoche and Zambezi valleys, are recognized in the upstream portion of 
the Zambezi Fan and highlight a westward (anticlockwise) shift of feeding axes. The central portion of the Zambezi Valley was affected by a progressive structural doming during the Miocene. The dominance of long-lasting erosional processes generated by the continuous rise of the seabed led to a deep entrenchment of the Zambezi Valley. This tectonicallycontrolled over-incision is believed to be the cause of the absence of Miocene levees, and has played an important role in the stabilization of the valley at its current position. Finally, our study revealed a quasi-constant development of contourite accumulations since the Late Miocene that occur most often synchronous with turbiditic sedimentation. The present study offers unique insight into the controls and stages of development of one of the largest turbidite systems in the world and demonstrates especially its susceptibility to structural activity.

Keywords: Zambezi turbidite system, Mozambique Channel, multichannel seismic profiles, turbidite, contourite, tectonic, Late Cenozoic

\section{INTRODUCTION}

Tectonic settings and sediment transfer are known to play an important role in the development and characteristics of deep-marine turbidite systems (Stow et al., 1985; Mutti and Normark, 1987, 1991). Besides possible regulation of upslope sediment flux and sediment delivery configuration (e.g. Stow et al., 1985; Reading, 1991; Reading and Richards, 1994), tectonics may deform basin floor topography and hence exert strong control on the morphodynamic evolution of a sedimentary system (Alexander and Morris, 1994; Bursik and Woods, 2000; Haughton, 2000; Morris and Alexander, 2003; Mayall et al., 2010; Howlett et al., 2020). Pre-existing features forming positive relief and/or tectonic movements (by faults, folds, salt or mud diapirs, salt walls, etc.) can disrupt the continuity of sediment flows and cause unusual geometries and sediment distribution patterns as they can lead to: (1) deflection, or the shifting of sediment routing due to an active structure (e.g., TabernasSorbas Basin: Hodgson and Haughton, 2004; Niger Delta: Morgan, 2004; Angolan margin: 
Gee and Gawthorpe, 2006); (2) diversion, when the gravity-driven processes change course because of a pre-existing structure (e.g., Makran margin: Kukowski et al., 2001; southern Barbados prism: Huyghe et al., 2004; Brazilian slope: Smith, 2004; offshore Tanzania: Maselli et al., 2020); (3) confinement, which indicates the restriction of turbidity currents by adjacent structures (e.g., Lower Congo Basin: Oluboyo et al., 2014; Levant Basin: Clark and Cartwright, 2009); or (4) blocking, where seafloor relief prevents sedimentation downstream of a structure (e.g., Gulf of Mexico: Rowan and Weimer, 1998; Beaubouef and Friedmann, 2000; Annot System: Sinclair and Tomasso, 2002; Fangliao Fan: Hsiung et al., 2018) of sediment pathways. Moreover, the crossing of a tectonic structure - which occurs if the erosional downcutting of sediment transport systems keeps pace with the rate of structural growth — can lead to a local or more extended topographic constriction of turbidity currents impacting flow behavior and sedimentation patterns (e.g., Gee et al., 2001; Morgan, 2004; Saller et al., 2004; Mayall et al., 2010). Although the principal anticipated response of deepwater gravity flows to structural elements are known, it is still a challenge to elucidate the depositional architectural evolution of extensive submarine turbidite systems to complex seafloor deformations.

The Mozambique Channel, hosting the Zambezi turbidite system, that has arisen from the break-up of Gondwana and the development of the East African rift system (e.g., Mougenot et al., 1986; Salman and Abdula, 1995; Calais et al., 2006; Leinweber and Jokat, 2012; Saria et al., 2014; Franke et al., 2015; Courgeon et al., 2018; Deville et al., 2018; Thompson et al., 2019) is known to be a tectonically dynamic region and hence, provides an interesting research area to explore the role of large-scale structural features and processes on the growth and evolution of a deep-water turbidite depositional system. Based on seismic reflection profiles, a number of previous studies on the Zambezi system have already hinted at a significant impact of morpho-tectonic features (i.e., Davie Ridge and lles Eparses and seamounts) that caused the stable position of the Zambezi Valley and its resulting unusual deep entrenchment (Lort et al., 1979; Droz and Mougenot, 1987; Castelino et al., 2017). Unfortunately, the findings of these studies were hampered due to the low-resolution data 
quality and/or insufficient seismic coverage. Other authors (e.g., Breitzke et al., 2017; Fierens et al., 2019; Miramontes et al., 2019) have suggested the important influence of oceanic bottom currents on the Zambezi Valley morphology. However, it seems unlikely to attribute the total deep entrenchment of the Zambezi Valley ( 700 m; Fierens et al., 2019) merely to erosional activity of deep-water bottom currents (max. 500 m of incision; García et al., 2009; Van Rooij et al., 2010; Bozzano et al., 2021; Miramontes et al., 2021) and so it has not yet been possible to ascertain the precise cause of the deeply incised morphology of the Zambezi Valley. This study based on a new and extensive high-resolution seismic reflection dataset from the Zambezi depositional system seeks to improve our understanding of the regional sedimentary evolution. The main seismic facies and incisions are examined in order to explore and characterize the timing and extent of erosion and deposition in the Zambezi turbidite system from Oligocene to present-day. This specifically allows us to decipher which mechanisms are responsible for the exceptional deep entrenchment of the Zambezi Valley.

\section{REGIONAL SETTING OF THE MOZAMBIQUE CHANNEL AND ZAMBEZI TURBIDITE SYSTEM}

The Mozambique Channel is located in the western Indian Ocean between Mozambique (East Africa) and Madagascar (centered at $40^{\circ} \mathrm{E}$ and between $15^{\circ} \mathrm{S}$ and $42^{\circ} \mathrm{S}$ ) (Fig. 1). 

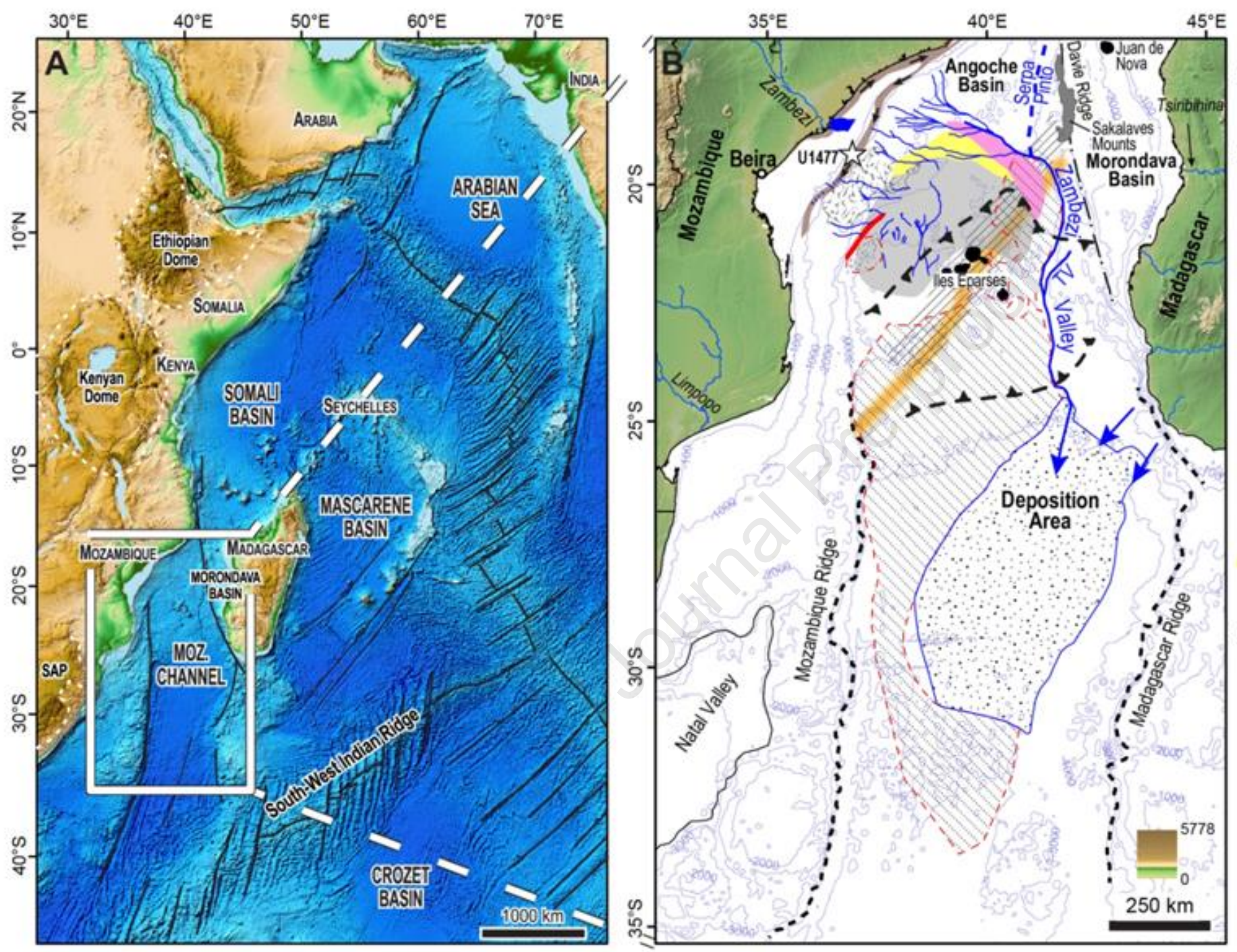

Shelf dynamics

7 Inner and outer mud belt (1)

Sedimentary features

Turbiditic features

.... Distal Depositional Area (2 \& 3)

Chinde-Zambe

paleo-valley (4)

- Canyon/Valley (5)

Channels (6)

Intermediate Basin (2)

Contouritic features

- Contour current

Dedforms $(2,7 \& 8)$

Dritt (6)

Moat (6)

Oligocene contouritic

Neogene dritt (9)

\section{Structural features}

Beira High (10)

Davie Ridge (11)

U// Fractured zone (12)

_. Buried prolongation of

- Davie Ridge (11)

Late Miocene doming (13)

... Scarps

Quathlamba Seismic Axis (14) 
Figure 1: (A) Location of the Mozambique Channel in the southwest Indian Ocean, with position of the main sedimentary basins, fracture zones (black lines) and continental elevation highs (white dotted lines) (modified from Delaunay, 2018; map from Amante and Eakins, 2009). SAP: South African Plateau. (B) Physiographic map of the Mozambique Channel showing main sedimentary and structural features (modified from Fierens et al., 2019). TV = Tsiribihina Valley. White star: core U1477 from IODP leg 361 (Hall et al., 2016). Compiled from published literature: (1) Schulz et al., 2011; (2) Fierens et al., 2019; (3) Kolla et al., 1980a; (4) Beiersdorf et al., 1980; (5) GEBCO, 2014; (6) Wiles et al., 2017; (7) Kolla et al., 1980b; (8) Breitzke et al., 2017; (9) Raisson et al., 2016; (10) Mahanjane, 2012; (11) Mahanjane, 2014; (12) Schematized from Courgeon et al., 2017, 2018; Deville et al., 2018 and Wiles et al., 2020; (13) Ponte, 2018, partly based on Baby, 2017; (14) Stamps et al., 2015.

\subsection{Structural evolution}

The formation of the Mozambique Channel was initiated in the Early Jurassic-Early Cretaceous during the breakup of the Gondwana (Salman and Abdula, 1995; Leinweber and Jokat, 2012; Thompson et al., 2019). Multiple rifting phases allowed the East Gondwana (Madagascar, Antarctica, India and Australia) to separate from the African block at ca. 165 Ma and slide southward along the transform Davie Fracture Zone (Fig. 1B) until around 120 Ma (Segoufin and Patriat, 1981; Coffin and Rabinowitz, 1987; Cochran, 1988; Gaina et al., 2015). During the Late Cretaceous (95 Ma) Madagascar separated from the Indian block (Salman and Abdula, 1995) and acquired its current position at $88 \mathrm{Ma}$ (Late Cretaceous) (Reeves, 2014; Thompson, 2017). The East African continental margin underwent a period of stabilization during the Paleocene and the Eocene, until rifting resumed when the East African Rift System (EARS) developed (Salman and Abdula, 1995; Calais et al., 2006; Saria et al., 2014; Franke et al., 2015). The eastern branch of EARS initiated in the Oligocene (Dawson, 1992; Le Gall et al., 2008) and is prolonged offshore along the North Mozambique coastline and northern part of the Mozambique Channel (Mougenot et al., 1986; Franke et 
al., 2015). This offshore rift segment is characterized by Neogene extension superimposed on earlier strike-slip structures of the Davie Fracture Zone (Rabinowitz et al., 1983; Reeves, 2014; Franke et al., 2015). A southwest prolongation of this offshore branch is argued by Courgeon et al. (2018), Deville et al. (2018) and Wiles et al. (2020) on the basis of a NNESSW densely distributed fault pattern, extending further south than the Sakalaves to the Mozambique Ridge on the East African Margin. These faults deformed the oceanic lithosphere of the Mozambique Channel in the same direction as the Agulhas-Falkland transform fault zone from at least Miocene times and are spatially associated to the Quathlamba active Seismic Axis (QSA) (Fig. 1B) (Stamps et al., 2015).

\subsection{Present-day morphology and main morpho-tectonic features}

The Mozambican shelf off the Zambezi River mouth gets connected to the deepest portions of the Mozambique Basin by the long and curvilinear Zambezi Valley that constitutes the main morphologic feature of the Zambezi Fan (Fierens et al., 2019) (Fig. 1). At present, no direct connection is known between the Zambezi River outlet and the Zambezi Valley. This submarine valley has a NW-SE orientation in its upper portion, transverse to the Mozambique Margin. It deflects towards the south when it approaches the Davie Ridge and passes through the Quathlamba Seismic Axis (Stamps et al., 2015) that is still active today (Courgeon et al., 2018; Deville et al., 2018; Wiles et al., 2020). The valley runs thereon between the Eparses carbonate platforms (Courgeon et al., 2016) to the west and the Madagascar margin to the east (Delaunay, 2018). At around $22^{\circ} \mathrm{S}$, the Zambezi Valley coalesces with the Tsiribihina Valley (TV in Fig. 1B) that originates from the Western Madagascar margin. Approximately at the latitude of the southern tip of Madagascar the

151 valley leads to a rather flat area constituting the Mozambique deep Basin. Between $22^{\circ} S$ and

$15226^{\circ} \mathrm{S}$, the valley crosses an elevated area that has undergone structural doming during the Late Miocene (Ponte, 2018). 
154

155

156

157

158

159

160

161

162

163

164

165

166

167

168

169

170

171

172

173

174

175

The Davie Ridge is a $1200 \mathrm{~km}$-long prominent N-S trending bathymetric high crossing the Mozambique Channel from the northeastern Mozambique to the southwestern Madagascar margin. It served as a morphological barrier for sediments originating from Madagascar, trapping the sediments in the Morondava Basin until the Miocene (23 Ma, Delaunay, 2018). Subsequently, this basin was filled in and allowed the Madagascar river inputs to overspill and contribute to the Zambezi Fan via the Tsiribihina Valley.

About $80 \mathrm{~km}$ off the Mozambican coast, the NE-SW Beira High (Fig. 1) forms a prominent basement high parallel to the Mozambique margin (Mahanjane, 2012; Mueller et al., 2016). This now buried structure is $300 \mathrm{~km}$ long and $100 \mathrm{~km}$ wide and served as a morphological barrier for sediments originating from the Mozambique margin until the Middle Miocene.

The central lles Eparses are steep sloped carbonate platforms developed on top of volcanic edifices relating to an Oligocene to Early Miocene volcanic episode (Courgeon et al., 2016; Jorry et al., 2016). The lles Eparses and the Beira High limit a small intraslope basin that has been named the "Intermediate Basin" (Fierens et al., 2019). This basin constitutes the more recent depositional system (Fierens et al., 2020).

\subsection{Sediment sources}

The Mozambique margin records a total sedimentary thickness of ca.6 stwt ( 12 km) (Ponte, 2018; Ponte et al., 2019) and sediment deposition started at Early Cretaceous.

The main source of sediment filling the Mozambique Basin is the Zambezi River, which is with a catchment area of $1.3 \times 10^{6} \mathrm{~km}^{2}$ the fourth largest river on the African continent (Fig. 2) (Thomas and Shaw, 1988; Walford et al., 2005; Milliman and Farnsworth, 2011). 


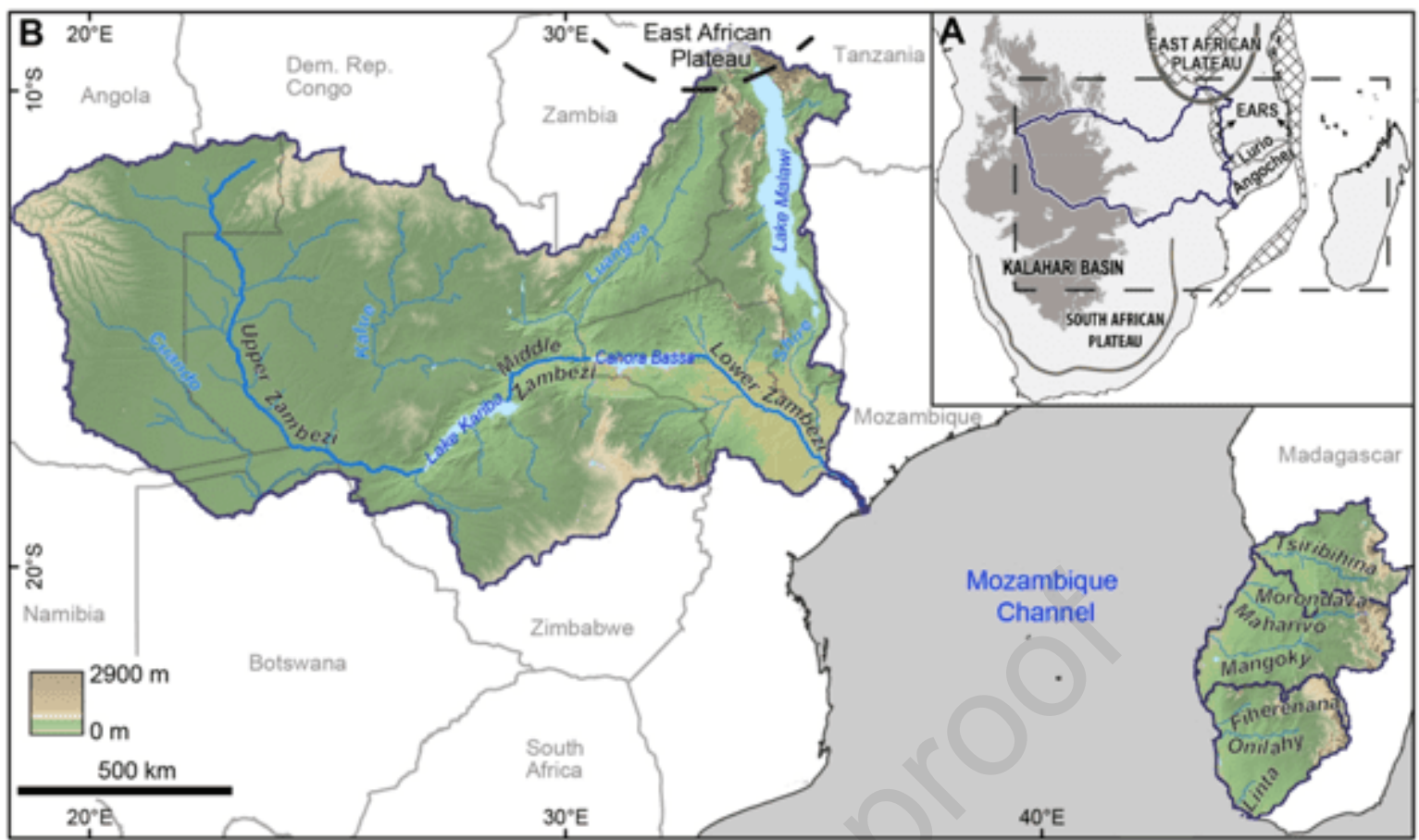

Figure 2: The Zambezi River and Madagascar Rivers catchments. (A) Position on the African continent (blue line) with indication of the major geomorphological and structural features (plateaus, basins, rift systems) (modified from Ponte, 2018; Courgeon et al., 2018; Deville et al., 2018). Cross design = rift systems and EARS = East African rift system. $(B)$ Modern drainage system of the Zambezi, Tsiribihina, Mangoky and Onilahy rivers shown on topography (GEBCO, 2014). The Mongoky catchment area includes the Mangoky, Maharivo and Morondava rivers. The Onilahy catchment comprises the Onilahy, Linta and Fiherenana rivers.

The Zambezi River originates in central southern Africa and drains on its eastern portion major parts of the East African Rift System as well as the NE portion of the Kalahari Basin of the South African Plateau (Fig. 2A). It has had a polyphase evolution and has fed the Mozambican margin with fluctuating composition mixture of sediment (Garzanti et al., in press). The Zambezi River has a sediment load of $48 \times 10^{6} \mathrm{t} / \mathrm{yr}$ (Nugent, 1990; Milliman and Syvitski, 1992) and is $2,575 \mathrm{~km}$ long with a third of its length at an altitude higher than $850 \mathrm{~m}$. From the African continent, two other important sources of sedimentary inputs have been observed: the Lurio (during Oligocene times) and Angoche (during Oligocene-Neogene period) watersheds (Fig. 2A). Western Madagascar rivers also contribute, but for a minor 
194

195

196

197

198

199

200

201

202

203

204

205

206

207

208

209

210

211

212

213

amount, to the deposition in the Zambezi turbidite system (Fig. 2B). Madagascar sediment inputs are originating mainly from the Tsiribihina River $(525 \mathrm{~km}$ long, catchment area of $49,800 \mathrm{~km}^{2}$ ) which is connected to the Zambezi Valley by the submarine Tsiribihina Valley. The Mangoky River which drains the largest watershed in Madagascar $\left(\sim 55,750 \mathrm{~km}^{2}\right)$ is probably also connected to this Tsiribihina Valley. The complex of Onilahy and Fiherenana rivers directly feed the distal turbidite system in the deep Mozambique Basin.

\subsection{The Zambezi turbidite system}

The vast amounts of sediments discharged onto the Mozambican continental shelf by the Zambezi River is attested by the very high sedimentation rate registered for the last climate cycle by IODP drilling U1477 (about $1 \mathrm{~m} / \mathrm{kyr}$ as a mean sediment rate for the last $120 \mathrm{kyr}$; Leg 361, Hall et al., 2016) and during the Late Glacial Maximum (LGM, 26.5-20 ka BP) as attested by the MOZ4-CS17 core (reaching about 2-3 m/kyr, Zindorf et al., 2021) both cores retrieved on the upper slope in extension of the Zambezi Delta (Fig. 1B).

Fierens et al. (2019) showed that the fluvial input of the Zambezi River is deposited into two main depocenters (Fig. 3) that together compose the Zambezi turbidite system: the Zambezi Fan, which is fed by the $1500 \mathrm{~km}$ long entrenched Zambezi Valley that transfers sediments to the deep basin in a vast zone of distal deposition ("Depositional Area", Fig. 3) and a Ponded Fan located in the Intermediate Basin, limited by the Mozambican slope and the lles Eparses. 


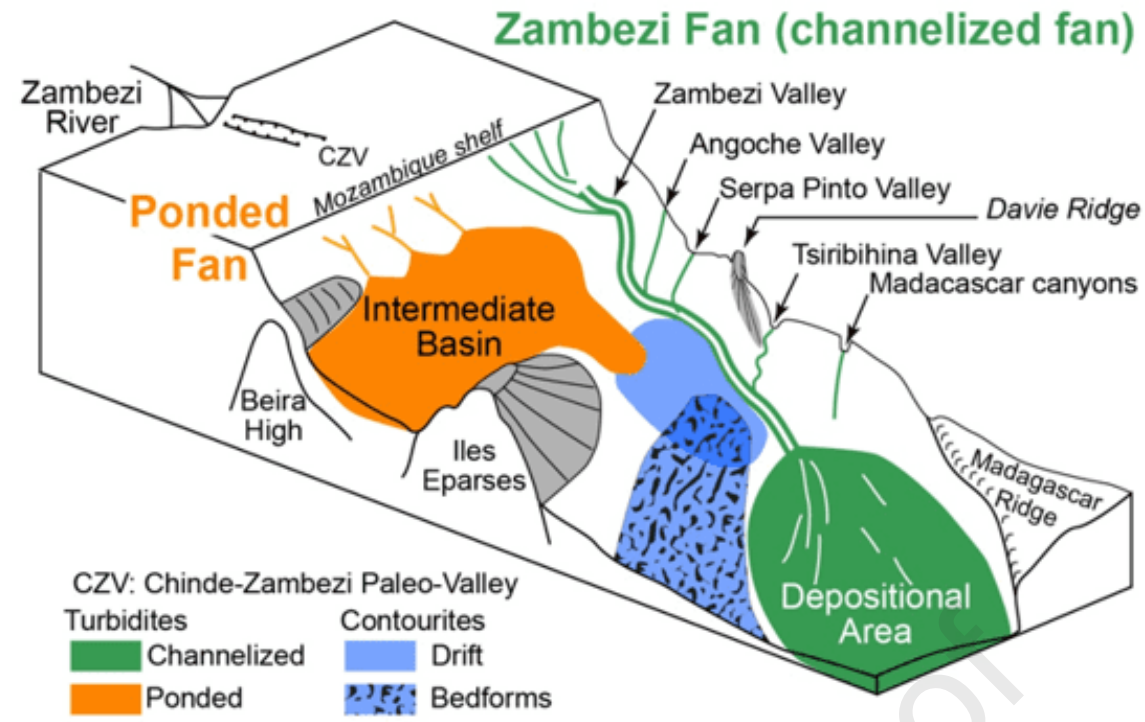

Figure 3: Major elements composing the Zambezi turbidite system (modified from Fierens et al., 2019).

The Zambezi Fan has been studied previously by multiple studies (e.g., Simpson, 1974;

Kolla et al., 1980a, 1980b; Droz and Mougenot, 1987; Breitzke et al., 2017; Wiles et al., 2017a; Miramontes et al., 2019; Fierens et al., 2019, 2020). From these we know that the Zambezi Valley and the distal Depositional Area are characterized by coarse-grained deposits (Simpson, 1974; Kolla et al., 1980b; Fierens et al., 2019). The presence of sediment waves (Breitzke et al., 2017; Fierens et al., 2019) and the flank erosion of the Zambezi Valley (Miramontes et al., 2019) reveal important sediment reworking by strong bottom currents. In contrast, the Ponded Fan has been more poorly studied (Wiles et al., 2017b; Fierens et al., 2019, 2020). Based on sub-bottom profiler data, Fierens et al. (2019) suggested that the Ponded Fan mainly consists of fine-grained turbidites with thin sheet-like, coarse-grained interbeds.

The current Zambezi Fan was established from Oligocene times when the Zambezi Delta progradation was initiated (Droz and Mougenot, 1987; Ponte, 2018). Since then, large quantities of sediment have been drained from the Zambezi watershed causing a substantial progradation of the Mozambique shelf (Walford et al., 2005; Ponte et al., 2019) (Fig. 4). 


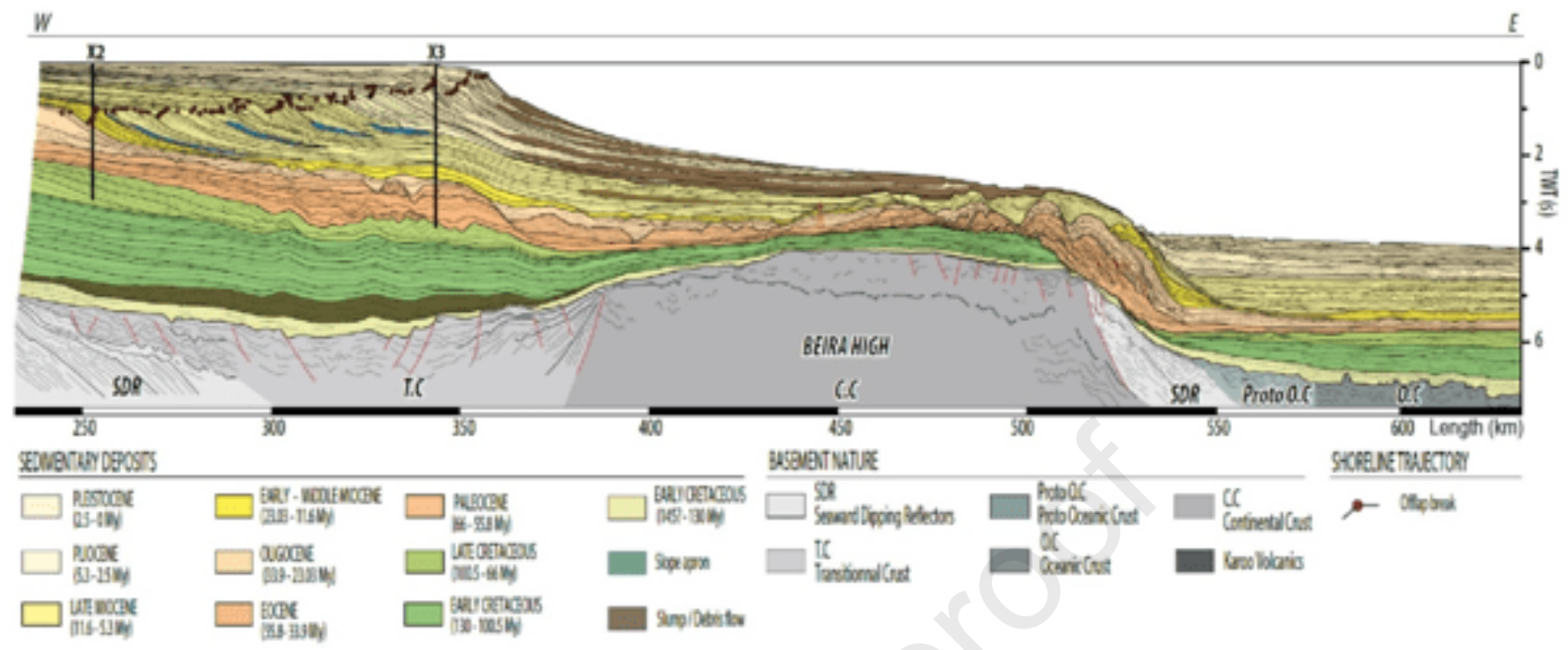

Figure 4: Stratigraphic architecture of the Mozambique margin (Ponte et al., 2019) (see location on Fig. 5).

The architecture of the Zambezi Fan is poorly known, except for the feeding axes of the fan.

Droz and Mougenot (1987) have shown that the initiation of the Zambezi Fan, during

Oligocene times was related to the Serpa Pinto Valley, a N-S feeding axis close to the Davie

Ridge (Figs. 1, 3). This valley received sedimentary inputs from the Lurio catchement (Roquette, 2016; Ponte, 2018) (Fig. 2A). The shift to the present-day NW-SE Zambezi Valley occurred in the Mid-Miocene possibly in response to tectonic activity induced by the development of the East African Rift System that affected the northern Mozambique margin. Ponte (2018) indicates that during Oligocene-Neogene times, sediments were supplied by the Angoche (Fig. 2A) and Zambezi watershed by several channeling systems that join the Serpa Pinto Valley (Oligocene) and later the Zambezi Valley (from Middle Miocene). Since the Middle Miocene, sediments from Madagascar contributed to the feeding of the Zambezi system (see section 2.2), funneled in the Tsiribihina Valley (Delaunay, 2018).

\section{MATERIAL AND METHOD}


255

256

257

258

259

260

261

262

263

264

(Bourillet et al., 2013): PTOLEMEE (Jorry, 2014), PAMELA-MOZ2 (Robin and Droz, 2014) and PAMELA-MOZ4 (Jouet and Deville, 2015) (Fig. 5). The PAMELA data are unevenly distributed across the study area with a majority located around the Zambezi Valley (Fig. 5A). The seismic lines are more dispersed on the Mozambican continental slope ( $\mathrm{N}$ to NE of lles Eparses) and in the distal Mozambique Basin.

On the Mozambican slope, the dataset was complemented with seismic data made available by Total. Additional seismic data from the MD163-MoBaMaSiS expedition (Reichert and Aslanian, 2007) were also used.

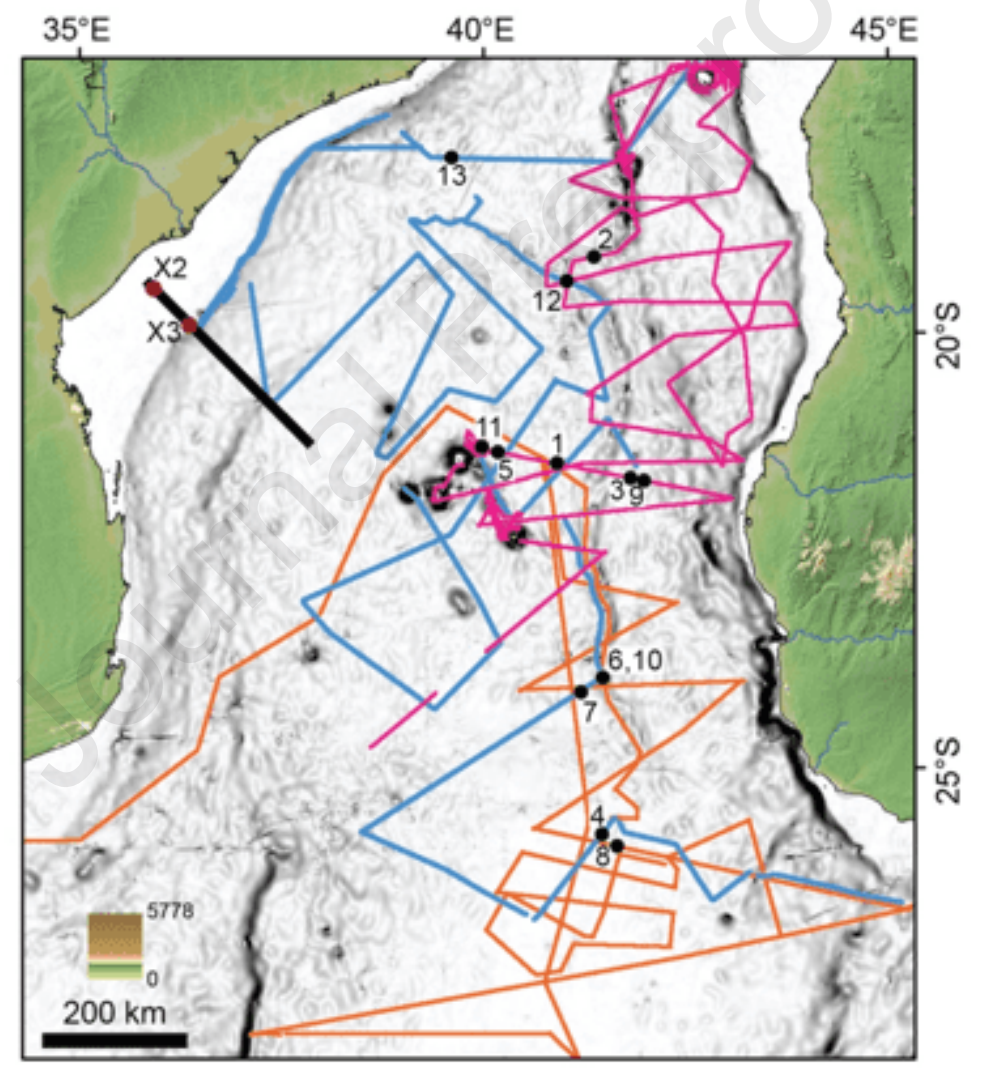

Figure 5: Data used in this study. PAMELA high-resolution multichannel seismic data set. Magenta lines: PTOLEMEE cruise (Jorry, 2014); orange lines: MOZ2 cruise (Robin and Droz, 2014); bleu lines: MOZ4 cruise (Jouet and Deville, 2015). Thick black line: position of the seismic line with industrial wells $(\mathrm{X} 2, \mathrm{X} 3)$ presented in Fig. 4 (Ponte, 2018). 1 to 13: location of the seismic facies examples shown in Fig. 6. 
272 This study used approximately $23,000 \mathrm{~km}$ of multichannel seismic data (Fig. 5) that were 273 acquired aboard of the L'Atalante and Pourquoi Pas? research vessels. The key parameters

274 of the seismic acquisitions are given in Table 1. The multichannel seismic data image the

275 sediment cover up to ca. 2-3 seconds two-way time (stwt), depending on the nature of 276 deposits and the bathymetric conditions.

277 


\begin{tabular}{ccc}
\hline Cruise & PTOLEMEE and & MOZ4 \\
\hline SOurce & 2 GI guns & 2 GI guns \\
& $(105$ and $45 \mathrm{ci})$ & $(105$ and $45 \mathrm{ci})$ \\
Receiving device & streamer & 48 traces \\
Acquisition speed & 24 traces & $8-10 \mathrm{knots}$ \\
Inter shot & $8-10 \mathrm{knots}$ & $10 \mathrm{~s}$ \\
Vertical resolution & $10 \mathrm{~s}$ & $(50 \mathrm{~m}$ at $10 \mathrm{knots})$ \\
\hline
\end{tabular}

279

Table 1: Acquisition parameters of the high-resolution multichannel seismic systems used during the PTOLEMEE, PAMELA-MOZ2 and PAMELA-MOZ4 cruises.

\subsection{PAMELA data processing}

The seismic data were processed using Ifremer in-house softwares Qc-SISPEED ${ }^{\odot}$ (PTOLEMEE, MOZ2) and SolidQC ${ }^{\odot}(\mathrm{MOZ4})$. The processing sequence includes quality controls of navigation and seismic data, binning, SEGD to SEGY format conversion, passband filtering $(15-150 \mathrm{~Hz})$, correction of source delay and stacking and migration at constant velocity $(1500 \mathrm{~m} / \mathrm{s})$.

\subsection{Seismic data interpretation}

Seismic interpretation was performed following the seismic stratigraphy principles (Mitchum et al., 1977). This approach involves the recognition and correlation of seismic units (definition according to Mitchum and Vail, 1977) complemented by an analysis of the seismic facies. The limits of these units are recognized by reflection terminations (onlaps, downlaps, erosional truncations, and toplaps). The geometry of reflections within an individual seismic unit is described using seismic facies analysis. Seismic facies are defined by looking at the internal and external configurations of the seismic units. Internal reflection characters are described by the continuity, amplitude, frequency and geometry of the reflections. The upper and lower boundaries of the seismic facies define its 2- or 3-dimensional external shape (e.g. 
wedge, lens or sheet geometry). The stratigraphic framework established by Ponte (2018) on the Mozambique margin (Fig. 4) served as a basis for our study.

The processed data (navigation and SEGY seismic files) were imported into the IHS Kingdom Suite ${ }^{\circledR}$ software that was used to display and analyze the data. Isopach maps were created with grid cell sizes of $200 \times 200$ m and produced in second two-way travel-time (stwt). A time-depth conversion is provided using an approximate velocity of $2000 \mathrm{~m} / \mathrm{s}$ (Ponte, 2018). With regard to the large size of the study area and the generally low density of the seismic data, the interpolation of seismic interpretations has been locally difficult. We have chosen to downgrade the isopach maps by showing a maximum of five classes of thickness (0.015-0.25, 0.25-0.5, 0.5-0.75, 0.75-1.0 and 1.0-1.634 stwt). The lowest value (0.015 stwt) corresponds to the vertical resolution of the seismic data with the lowest resolution (PTOLEMEE and MOZ2 data, see Table 1). These isopach maps were displayed by using ArcGIS® v10.3.1 (World Mercator map projection).

\section{RESULTS AND INTERPRETATION}

\subsection{Seismic facies and process-based interpretation}

The high-resolution multichannel (24- and 48-channels) seismic profiles of the Mozambique Channel reveal three main types of seismic facies that are those typically encountered on continental margins and in turbidite systems (e.g., Winker, 1996; Piper et al., 1999;

Babonneau et al., 2002; Adeogba et al., 2005): stratified (S), chaotic (C) and transparent (T) facies. Main characteristics of the facies are summarized in Table 2 and examples are provided in Fig. 6. 


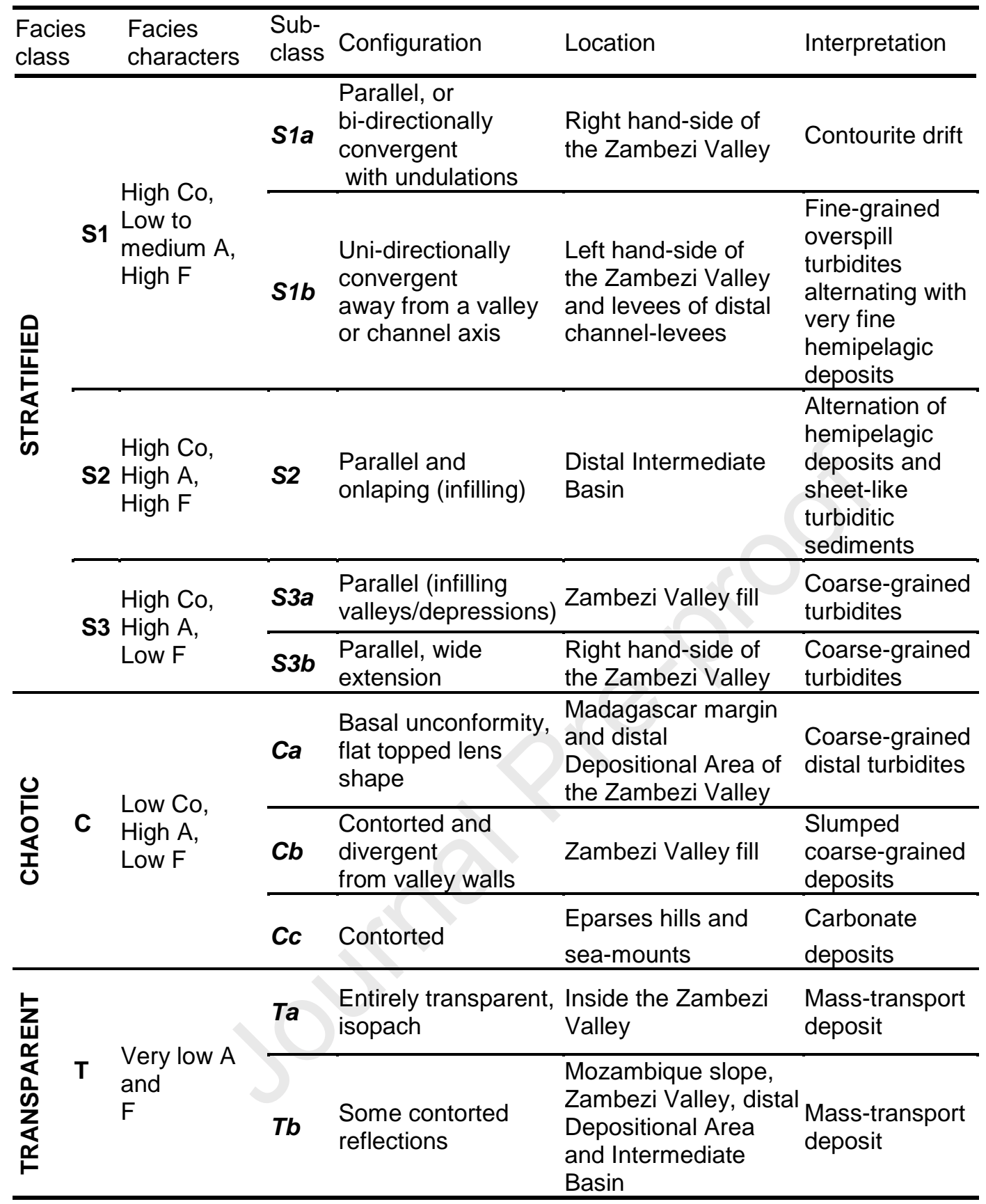

322 Table 2: Description and interpretation of the seismic facies encountered in the Zambezi

323 turbidite system. Facies characters are described in term of the continuity (Co), amplitude (A)

324 and frequency $(F)$ of the reflections. 


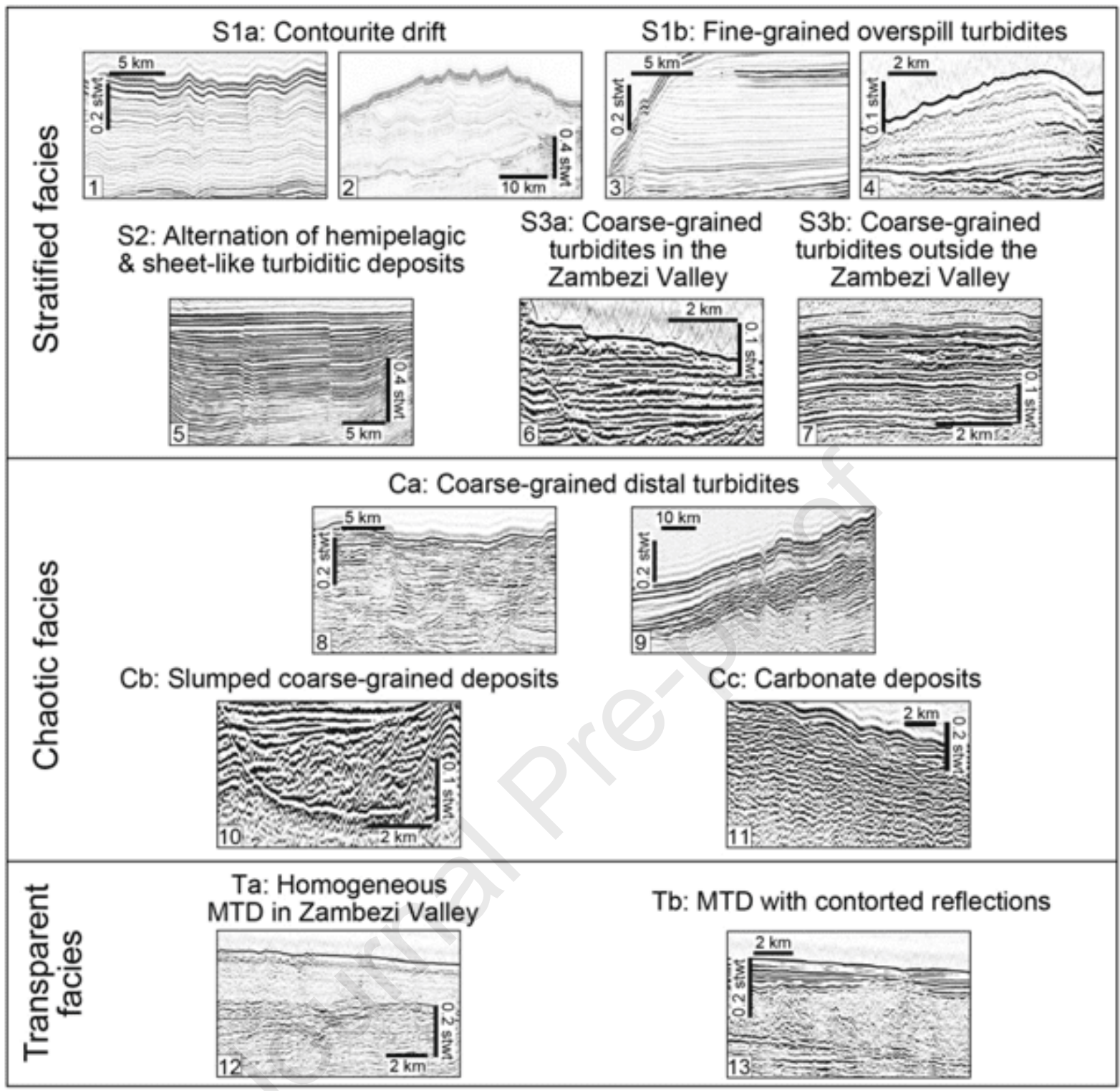

Figure 6: Examples of the seismic facies encountered in the Zambezi turbidite system

327 (location of line portions is shown in Fig. 5 as black dots 1 to 13).

The stratified facies (S) are the most common and widespread facies identified in the

Mozambique Channel. Their main characteristic is a generally good continuity of the reflectors that may be planar or undulated. Variations in amplitude, frequency and configuration led to recognize contouritic deposits (S1a), fine-grained overspill turbidites

333 (S1b), alternating hemipelagic and sheet-like turbiditic deposits (S2) and coarse-grained turbidites (S3a and S3b).

The chaotic facies $(C)$ are characterized by contorted reflections with low continuity and by frequent erosional features and local unconformities. The Ca facies are widely observed at 
the distal end of the Zambezi Valley where coarse-grained sediments dominate (Kolla et al., 1980a, b). In addition, local flat top lens-shaped seismic units are identified on the Madagascar slope where it is thought to image coarse-grained turbidites. The chaotic facies are also observed as contorted reflections that are tilted towards the valley axis $(\mathrm{Cb})$, which are interpreted as slumped deposits from the valley flanks in agreement with the interpretation of other authors (e.g., Deptuck et al., 2003; Janocko et al., 2013). At the foot of the seamounts of the lles Eparses, the Cc chaotic facies is interpreted as carbonated turbidites with hemipelagic muds (Counts et al., 2018).

The transparent facies $(\mathrm{T})$ are observed as homogeneously transparent inside the Zambezi Valley $(\mathrm{Ta})$ or as mostly transparent with faint and contorted reflections at various sites of the Mozambique margin and basin (Tb). These facies are usually interpreted as mass-transport deposits (MTDs) (e.g., Imbo et al., 2003; Garziglia et al., 2008; Loncke et al., 2009; Dennielou et al., 2019; Badhani et al., 2020).

\subsection{Architecture and stratigraphy of the Zambezi turbidite system}

\subsubsection{The Mozambique Basin feeding networks}

The PAMELA data with a water depth up to $2500 \mathrm{~m}$ and data from Total between $2500 \mathrm{~m}$ and $1000 \mathrm{~m}$ water depth show that the upper portion of the Zambezi Valley (i.e. most northwestern part) has been fed by two main converging tributary networks (Fig. 7A), the youngest Northern and the oldest Southern Zambezi network (Fierens et al., 2019). Tributaries of these networks do not show clear connections to the upper slope and disappear halfway up the slope. The absence of connection to the uppermost slope is not due to a lack of data, but rather because of the absence of lasting incisions upstream of the slope. The Intermediate Basin, in contrast, was fed by a loose network of parallel valleys distributed homogeneously along the Mozambique slope (black lines in Fig. 7A). 


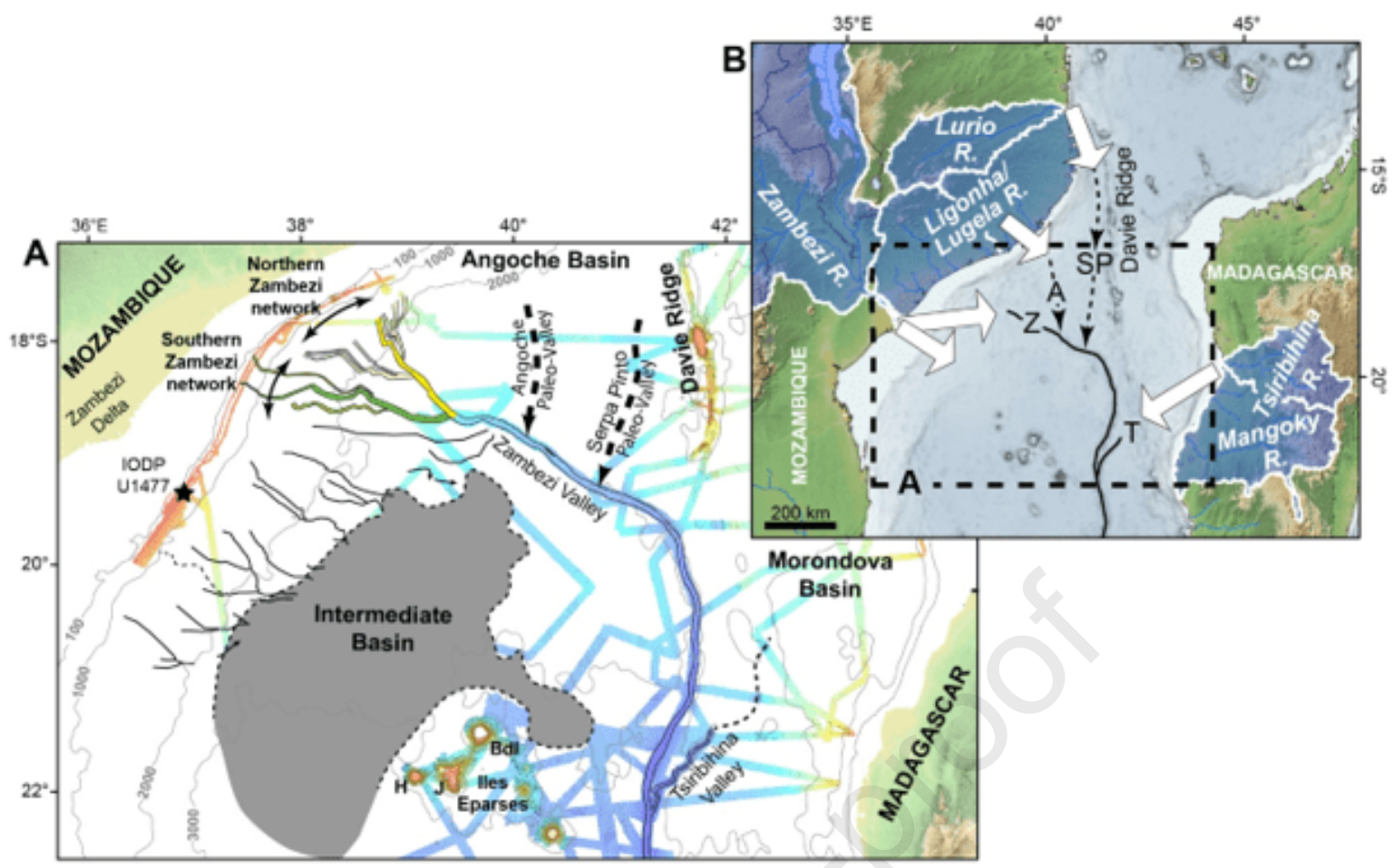

Figure 7: Marine feeding axes of the Zambezi turbidite system and continental sediment

sources. (A): Various submarine networks of the Zambezi Fan (Northern and Southern

Zambezi networks, Angoche and Serpa Pinto paleo-valleys and Tsiribihina Valley) and the ponded turbidites accumulated in the Intermediate Basin. Bdl: Bassas da India, H: Hall Bank, J: Jaguar Bank. (B): Main rivers feeding the Zambezi turbidite system (rivers watersheds from http://www.fao.org/geonetwork, 2019). Z: Zambezi Valley; T: Tsiribihina Valley; A: Angoche Paleo-Valley; SP: Serpa Pinto Paleo-Valley.

Downstream, the Zambezi Valley receives three main tributaries on its left hand-side: the Angoche, Serpa Pinto and Tsiribihina valleys (Fig. 7A). The valley that originates northwards from the Angoche Basin is referred to as the Angoche Valley in this paper. The Serpa Pinto Valley (Droz and Mougenot, 1987) originates from the Lurio watershed and possible other northeastern African drainage basins (Ponte, 2018) and runs adjacent to the Davie Ridge.

377 These two paleo-tributaries have a North-South orientation and provided sediments from the 378 Northern Mozambique rivers to the Zambezi Fan (Fig. 7B). The Tsiribihina Valley originates from the Western Madagascar margin (Tsiribihina and Mangoky drainage basins) and is currently providing sediments to the lower portion of the Zambezi Fan. 


\subsubsection{Seismic units}

Based on the seismic facies analysis and interpretation (see Section 4.1) we identified four main facies types: fined-grained overbank turbidites (lateral levees), coarse-grained turbidites (mainly channel fills or lobe complexes), fine-grained contourites (drifts) and masstransport deposits (MTDs, restricted in valleys or more widespread in the distal depositional area) (Fig. 8). These facies are organized into five main seismic units (U1 to U5) that are regionally correlated (Fig. 8A, 9). U1 to U4 are stacked up in the Zambezi Fan, while U5 corresponds to the Ponded Fan in the Intermediate Basin. Figure 10 shows the thickness maps (in sec TWT) of the 5 units that could be correlated throughout the study area. Additional units (Ua to Ug on Figs. 8A, 9) are observed locally in the Zambezi Fan, but the low density of seismic data prevents their correlation and they are not considered in this paper.

394 Towards the distal depositional area (Fig. 8B), we could not individualize U1 to U4, therefore, a single 1000 m-thick seismic unit called Depositional Area (DA) has been considered in this area. 

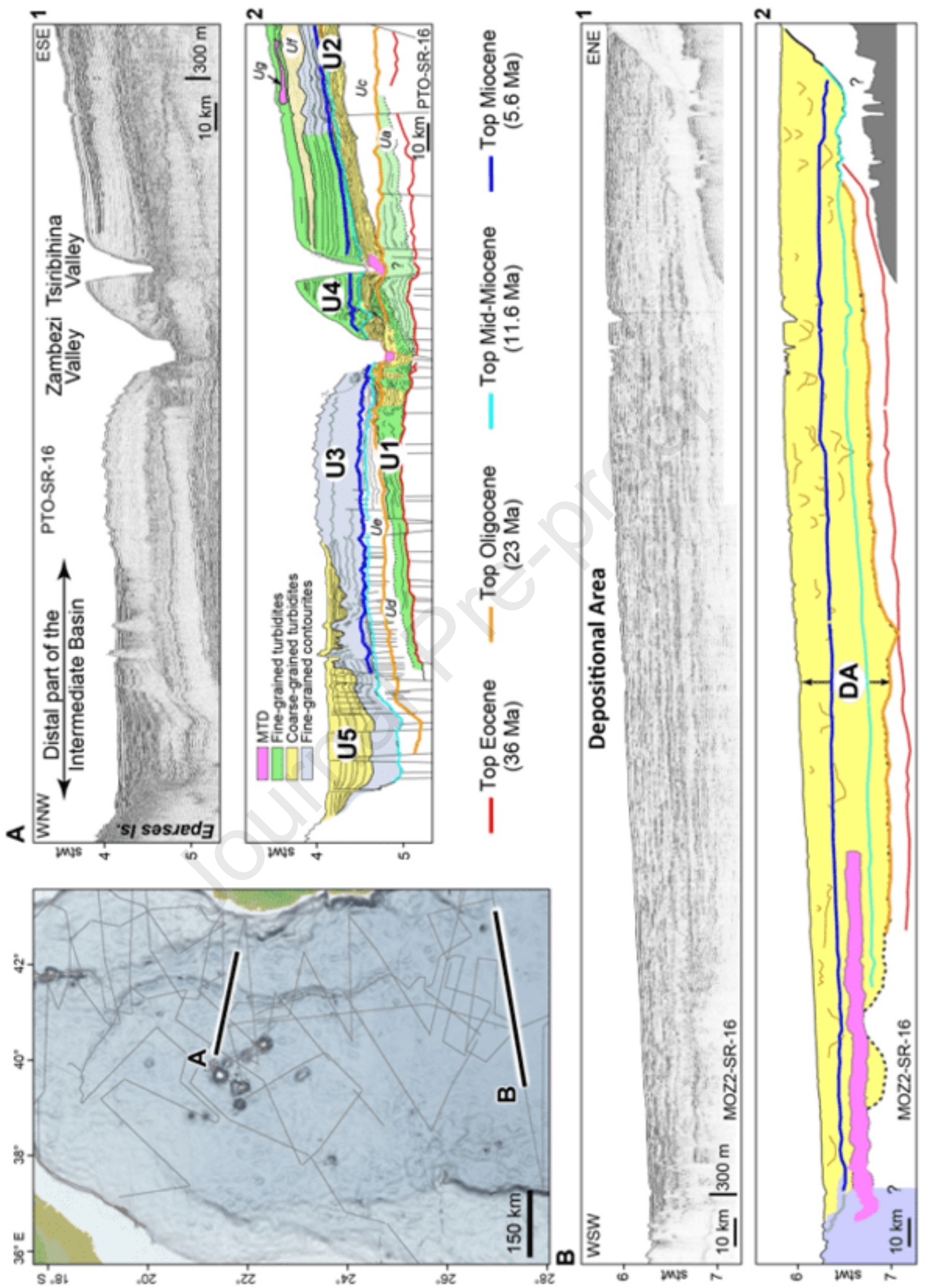
西

400 Figure 8: Seismic sections (with their location) illustrating the seismic facies, the regional

401 seismic units and Ponte's (2018) stratigraphy found upstream (A) and downstream (B) of the 

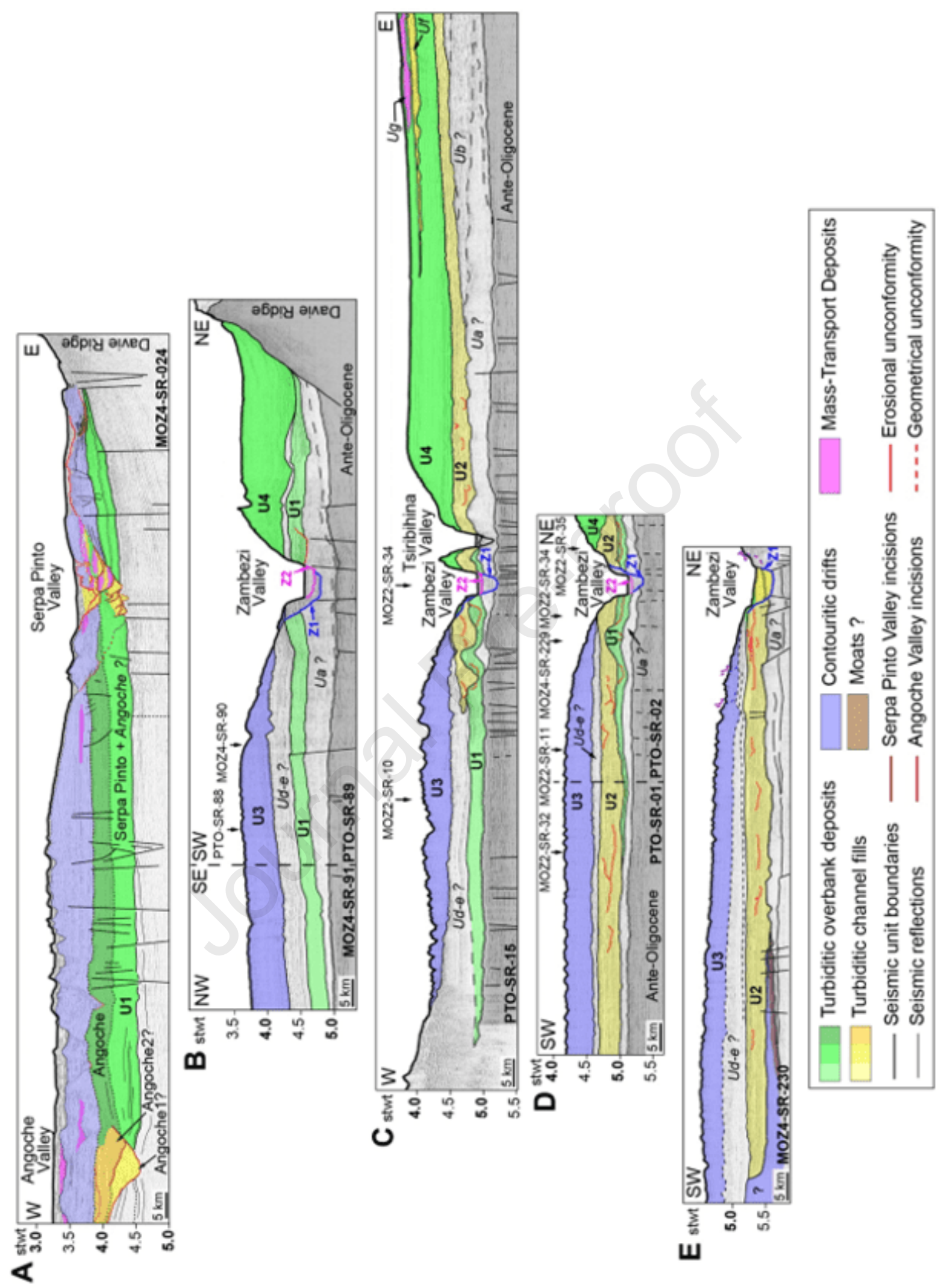

Figure 9: Interpreted seismic reflection profiles from north $(A)$ to south $(E)$ showing the major sedimentary evolution of the Zambezi turbidite system (see supplementary material A for uninterpreted profiles). Z1 and Z2 denote the main incisions of the Zambezi Valley. See Fig. $10 \mathrm{~A}$ for location of the seismic profiles. 


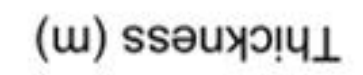

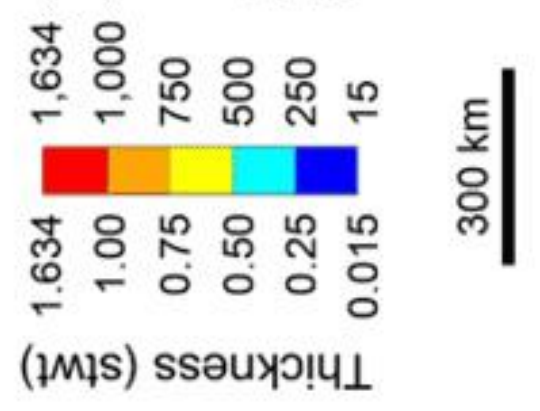

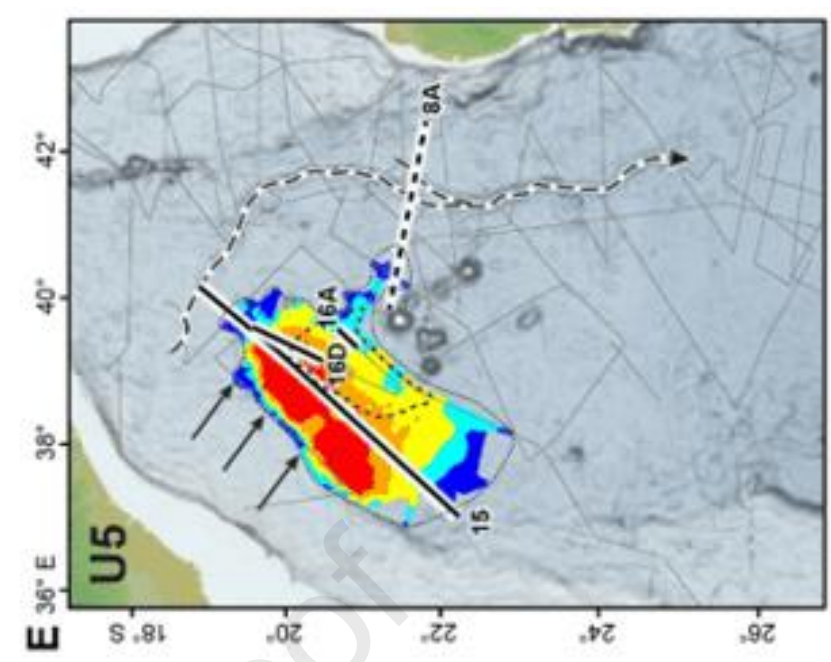
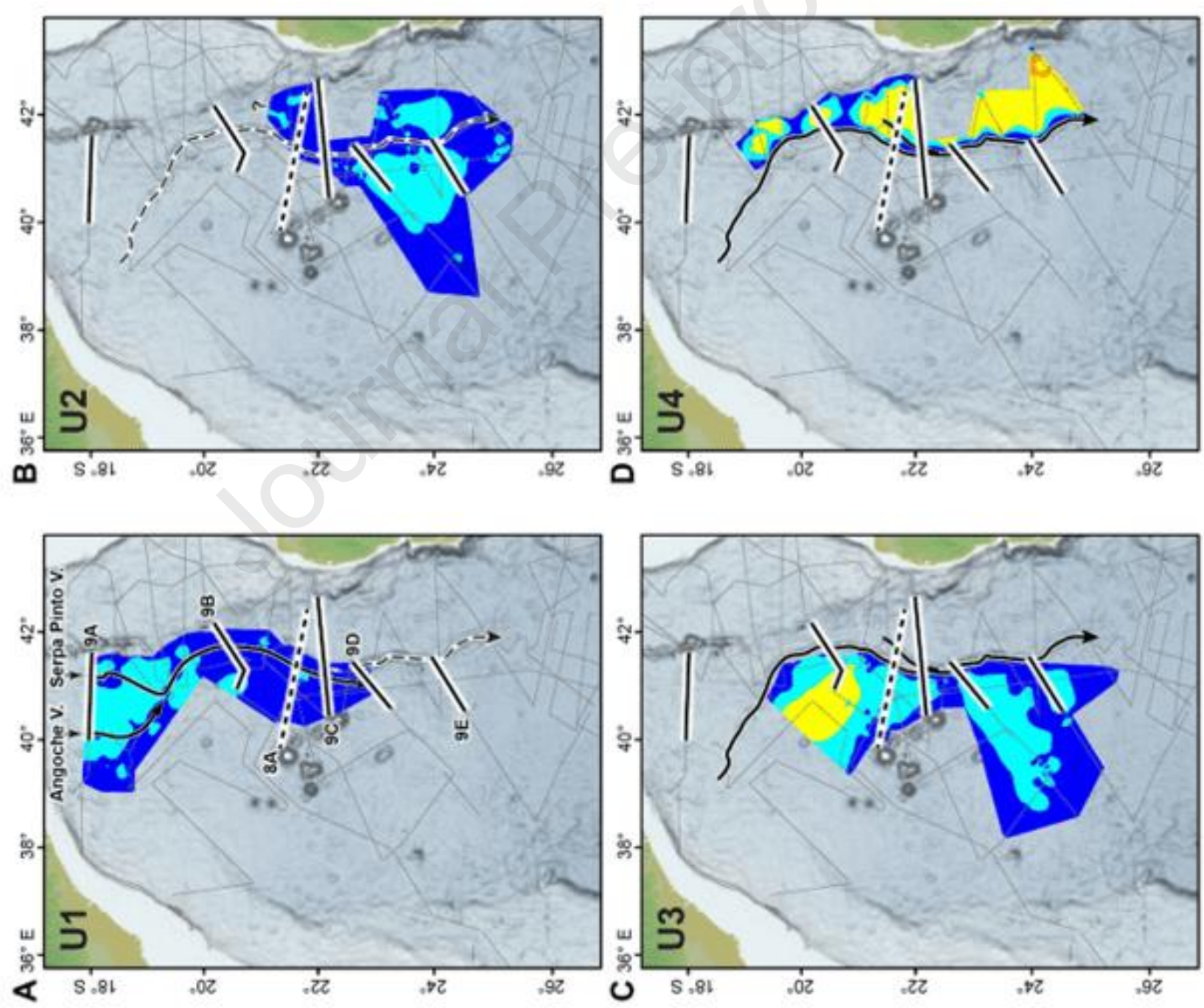

410 Figure 10: Distribution and thickness of the five seismic units of the Zambezi turbidite system

411 (Zambezi Fan, U1 to U4, and Ponded Fan, U5). The position of the Zambezi Valley is

412 indicated either as a dashed line when inactive (A, B, E) or as a continuous black line when 
active (C, D). The possible course of the Angoche and Serpa Pinto Valleys is additionally shown in A. Straight black and dashed lines are the location of seismic profiles of Figs. 8, 9, 15 and 16.

\subsubsection{Sedimentary evolution of the Zambezi turbidite system}

A general spatial overview (from north to south) of the architecture of the Zambezi Fan with the distribution of the seismic units is provided in figure 9. The distribution and isochore maps of the five main seismic units are provided in figure 10.

\section{Unit U1: Channel-Levee Complex}

Unit U1 (Figs. 8A, 9) is wedge-shaped and composed of the association of high-amplitude channel infilling facies (S3a) interpreted as coarse-grained turbidites and lateral low to medium amplitude, high-frequency S1b facies interpreted as fine-grained turbidites (Fig. 6 and Table 2). The convergent configuration distally from the valley is typical of overbank deposits (levees).

Unit $\mathrm{U} 1$ originates in the northern most part of the study area, in relation with the N-S oriented Serpa Pinto and Angoche valleys (Fig. 10A). The depositional history of the Serpa Pinto Valley appears especially complex with multiple episodes of cut-and-fill in link with overbank deposition and intercalated with small mass-transport deposits inside the channels (Fig. 11). Consequently, U1 is interpreted as a channel-levee complex comprising several channel-levee systems. Available data are too limited to allow an extensive interpretation of the activity of this valley, and therefore it has been considered as a thick single event in this study. In addition, in this northern area, overbank deposition from both the Serpa Pinto Valley to the east and the Angoche Valley to the west indicates that both valleys have been active synchronously and served as feeding axes to the so called Serpa Pinto channel-levee Complex (Fig. 9A, 10A).

U1, including the Angoche contribution, shows its maximal lateral extent (approximately 260 $\mathrm{km})$ and thickness $(0.5 \mathrm{stwt}$, i.e. $\sim 500 \mathrm{~m}$ ) in the upstream northern part (Fig. 10A). Close to 
441 the Davie Ridge a significant contribution of contouritic sedimentation led to the deposition of

442 thick contouritic drifts (S1a in Figs 6 and 9A).

443 The basal channels of the Serpa Pinto and Angoche Valley show limited erosion in the

444 Eocene-Oligocene strata, and appear as a flat and wide erosional unconformity (Fig. 11).

445 Downstream the confluence with the Zambezi Valley (Fig. 8A, 9B to 9D), the Serpa Pinto

446 Valley is more deeply incised, and disappears downstream because of over-incision of the

447 Zambezi Valley (see Section 4.2.4). Where the channels are still observed they are filled in

448 with typical channel infilling facies, i.e. discontinuous, high-amplitude and low-frequency

449 reflections (S3b in Fig. 6). The distribution of unit U1 (Fig. 10A) shows an approximate N-S

450 direction. The channels appear relatively close to the present-day position of the Zambezi

451 Valley except in the downstream extension of Unit U1 where they diverge toward the west

452 (Fig. 10A). U1 is identified and correlated downstream to a latitude just a bit further south

453 than the Tsiribihina confluence (Fig. 10A), however, the downstream extension of this unit

454 remains uncertain.
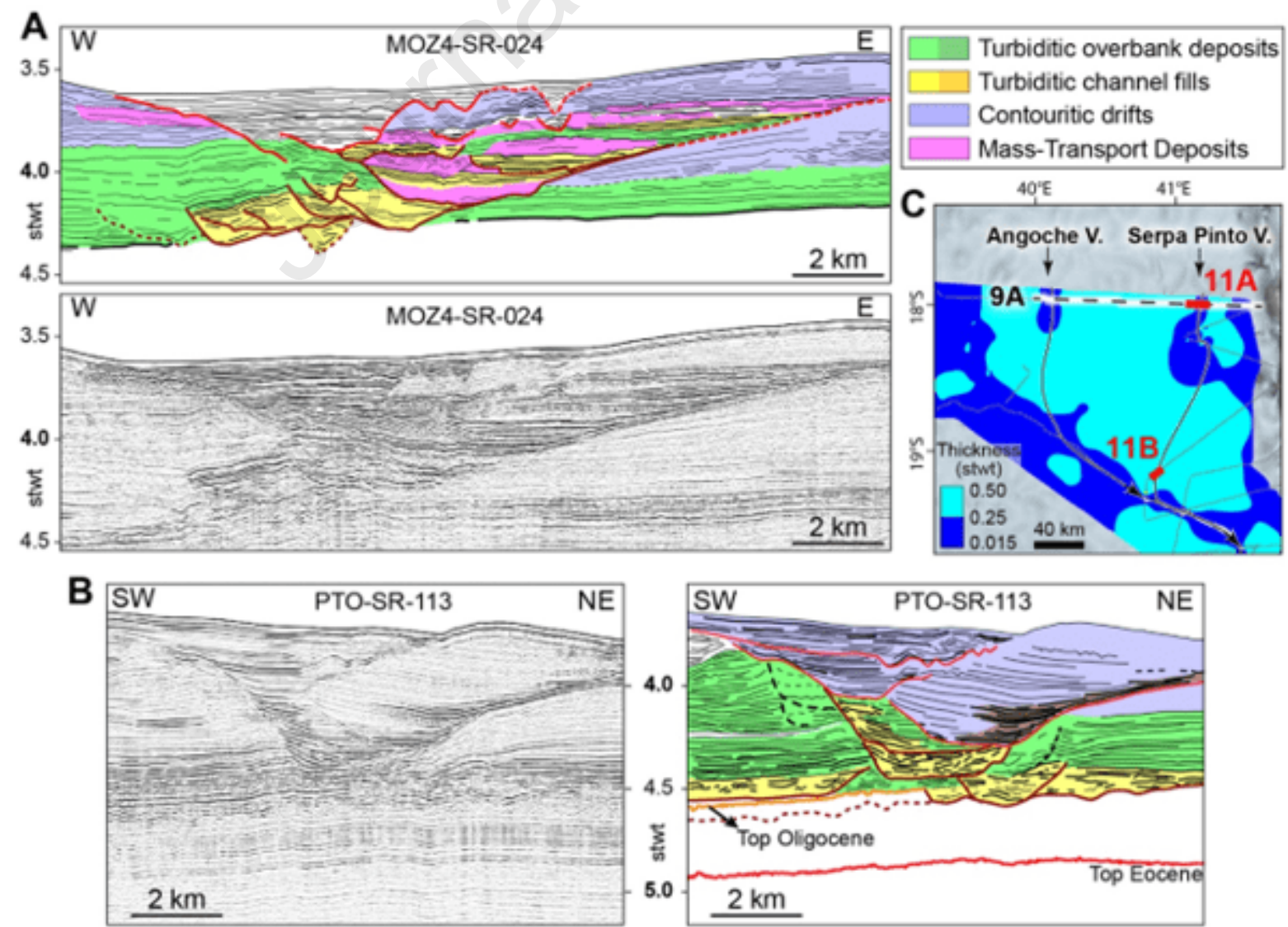
456

457

458

459

460

461

462

463

464

465

466

467

468

469

470

471

472

473

474

475

Figure 11: The Serpa Pinto Valley depositional succession. (A): Close up of seismic profile MOZ4-SR-24 (shown in Fig. 9A) illustrating the northern portion of the Serpa Pinto Valley. (B): Seismic profile PTO-SR-113 showing the southern portion of the Serpa Pinto Valley, close to the confluence with the Zambezi Valley. C: Close up of the distribution and isochore map of unit U1 (see Fig. 10A) showing the location of seismic lines A and B.

\section{Unit U2: Lobe Complex}

Unit U2 consists mainly of S3b facies (continuous, high-amplitude, low frequency reflections, with frequent local erosional unconformities) (Fig. 8 A, 9C-E) and is interpreted as coarsegrained turbidites.
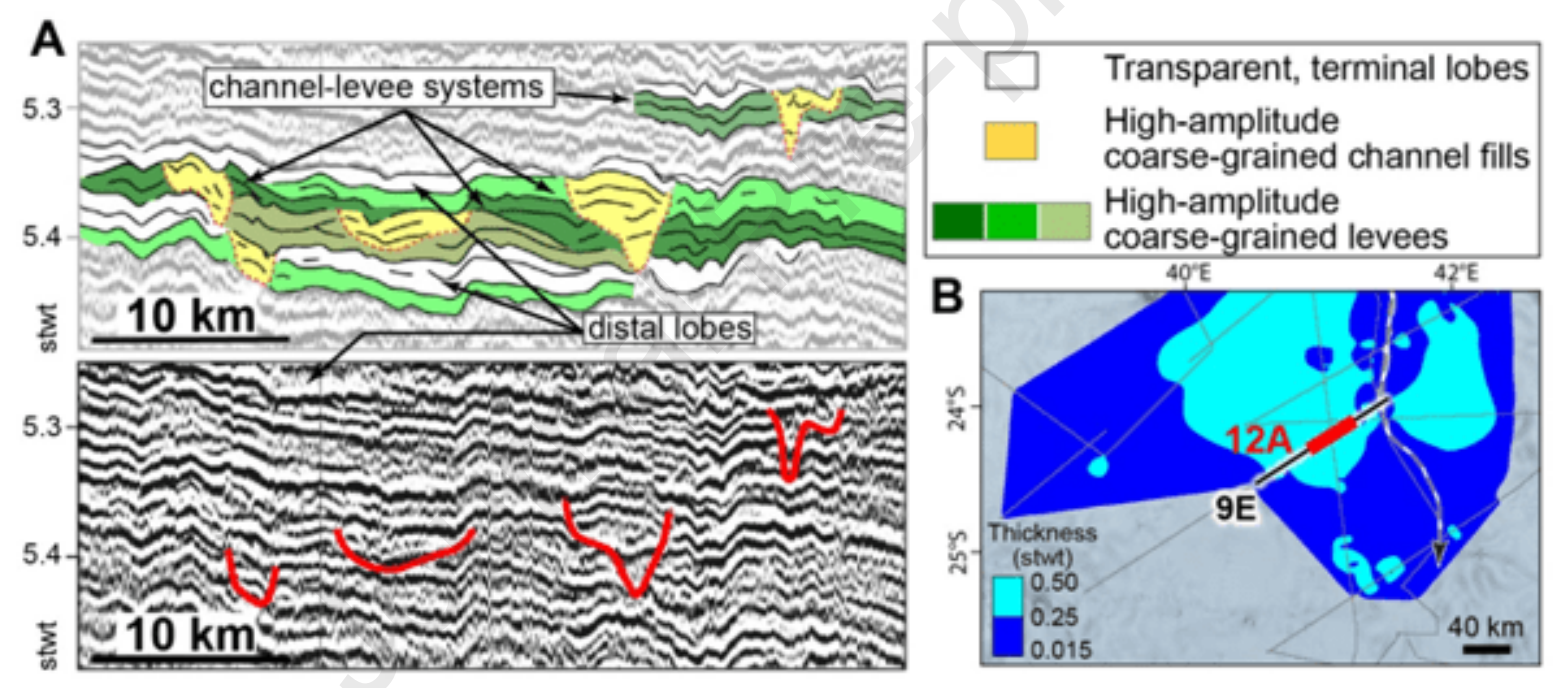

Figure 12: $(A)$ : Close-up of unit 2 showing the possible stacking of small coarse-grained channel-levee systems (seismic profile MOZ4-SR-230, Fig. 9E). (B): Zoom of the distribution and isochore map of unit U2 (see Fig. 10B) showing the location of seismic profile A.

The detailed internal organization of this high-amplitude unit (Fig. 12) reveals ca. 0.03 stwt ( $30 \mathrm{~m}$ ) thick wedge-shaped seismic bodies lateral to channel-like erosional features, evoking small and coarse-grained channel-levee systems which are stacked up in the dominantly high-amplitude facies. More continuous high-amplitude reflections and transparent levels intercalated with the channel-levee systems evoke coarse-grained sheet-like turbidites and 
terminal lobes, respectively. These seismic characteristics suggest that unit U2 is composed

of channel-mouth deposits, distinctive of distal depositional environments.

The distribution of unit U2 (Fig. 10B) shows a pear shape with an average NE-SW orientation, i.e. oblique to the current Zambezi Valley (Fig. 10). This unit is up to 0.4 stwt thick ( $\sim 400 \mathrm{~m}$, Fig 10 ) and is generally widespread (up to $\sim 330 \mathrm{~km}$ of lateral extent in its downstream portion, on Fig. 10B), more developed at the right hand-side of the Zambezi Valley. At its northeastern limit, unit U2 is mainly recognized on the left hand-side of the Zambezi Valley (Fig. 8A). Based on available data, it was not possible to extend this unit more to the north, so that we may only hypothesize on its origin (see Section 5.1). The southern limit of U2 extends more distally compared to unit U1. U2 is incised by the paleoincisions of both the Zambezi and Tsiribihina Valley (Figs. 8A, 9E), which might indicate that unit U2 pre-existed the development of these valleys or that the incision of these valleys has endured after the deposition of U2.

\section{Unit U3: Contourite drift on the western side of the Zambezi Valley}

Unit U3 (Figs. 8A; 9) is composed of continuous low-amplitude, mostly high-frequency reflections (facies S1a). This unit is up to $0.7 \mathrm{stwt}(\sim 700 \mathrm{~m})$ thick and shows a slightly domed wedged shape with bidirectional thinning. Close to the Zambezi Valley, the lateral thinning is partly due to erosion on the Zambezi Valley flanks. Reflections are parallel under the thickest part of the wedge and are affected by sediment bedforms that are observed in the whole vertical extent of the unit (Figs. 9, 13A). These bedforms, observed on bathymetric and subbottom profiler data (Fierens et al., 2019) are interpreted as bottom current controlled sediment waves. Based on the shape, the internal configuration and the similarities with other contourite drifts identified in the Mozambique Channel (Fig. 13B) or in literature (Hernández-Molina et al., 2010; Miramontes, 2016), U3 is interpreted as a contourite drift.

Westward at the distal and basal limit of the Intermediate Basin, approaching the lles Eparses, unit U3 appears to be locally structured by high reliefs wherein reflections are lost and the facies becomes mostly transparent (Fig. 8A). These reliefs are associated to a dense 
504 network of faults (Deville et al., 2018), mainly observed in the underlying units (Ud and Ue)

505 and evoke structural domes (associated to volcanism?).

506 Closer to the lles Eparses seamounts, high-amplitude reflections are intercalated in the

507 dominantly low-amplitude facies. They could represent detrital carbonate sediments

508 originating from the islands, synchronous with the contourite deposition (Counts et al., 2018).

509 Unit U3 is solely observed along the right (looking downstream) border of the Zambezi Valley

510 (Fig. 10C) and is locally less developed towards the SE of lles Eparses (Fig. 13C). The width

511 of the contourite drift reaches up to $\sim 300 \mathrm{~km}$ (Fig. 10C) and the unit is recognized along at

512 least $680 \mathrm{~km}$ from upstream to downstream. It is important to note that the northwestern and

513 southern limits of unit U3 remain uncertain due to the lack of data. 

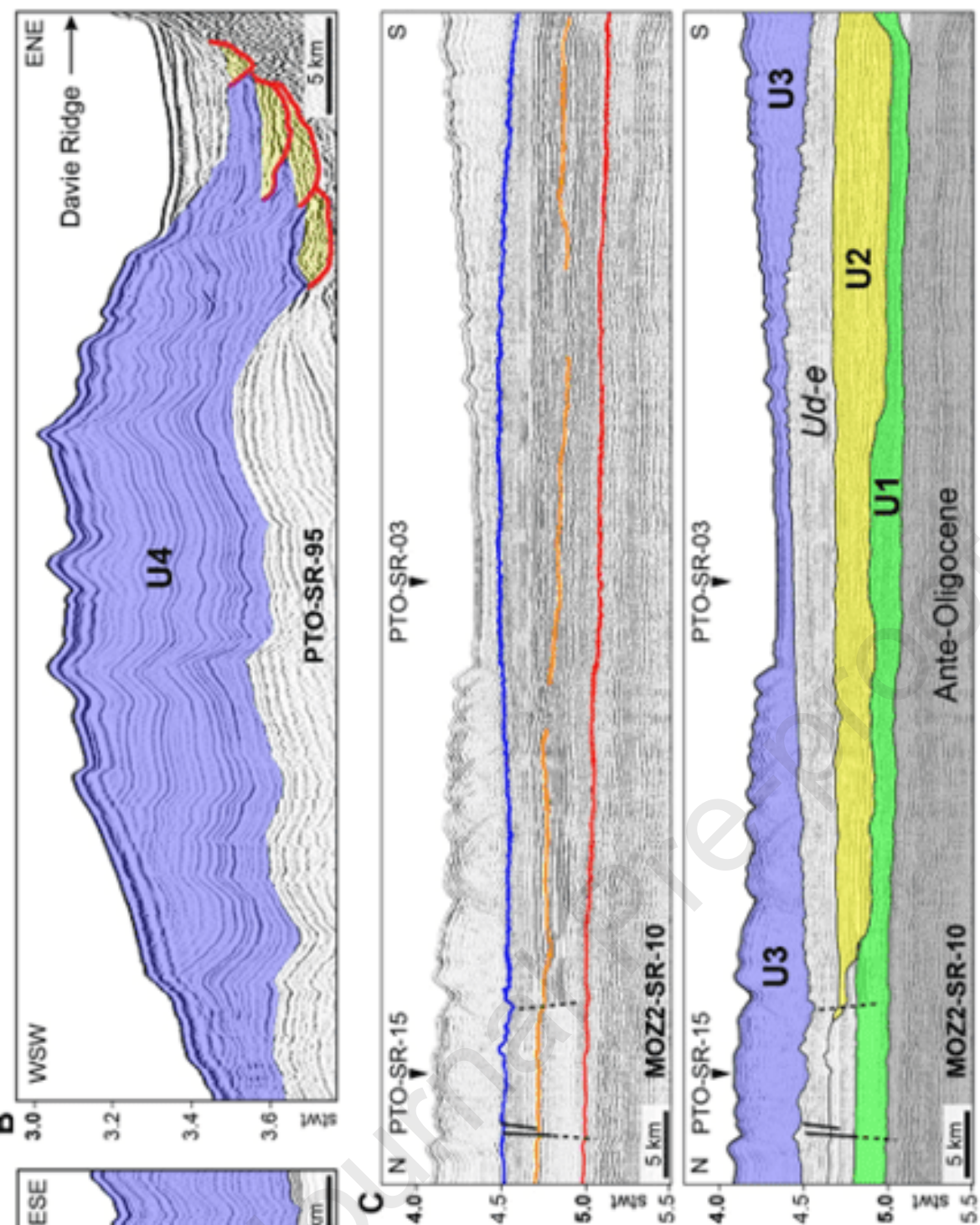

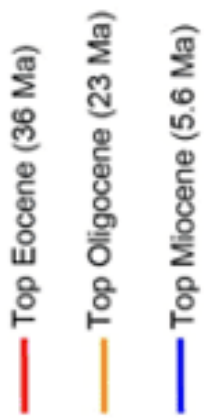
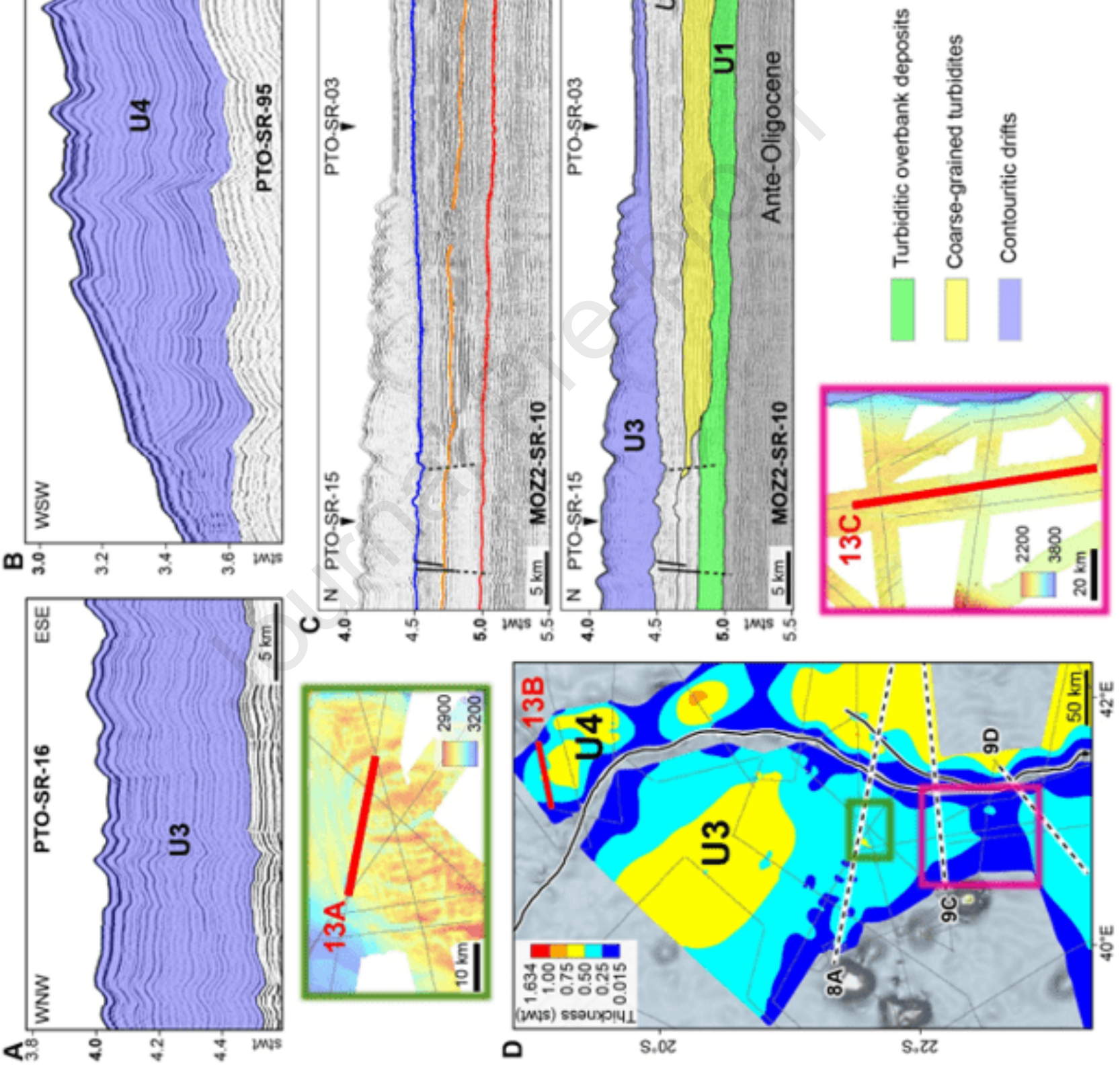

515 Figure 13: $(\mathrm{A})$ : Detail of unit U3 that is characterized by S1a facies affected by sediment

516 bedforms. (B): Example of contouritic sedimentation near the Davie Ridge as part of unit U4

517 that shows similar shape and internal configuration. (C): A second example of unit U3 more

518 to the south, where it is locally less developed. (D): Zoom of the distribution and isochore 
map of unit U3 (right hand-side of the Zambezi Valley, see Fig. 10C) and unit U4 (left handside of the Zambezi Valley, see Fig. 10D) showing the location of the seismic profiles. Enlarged bathymetric insets show the location of $\mathrm{A}$ and $\mathrm{C}$.

\section{Unit U4: Turbidite and contourite deposition on the eastern side of the Zambezi Valley}

The left bank (looking downstream) of the Zambezi Valley and both flanks of the Tsiribihina Valley are mainly composed of stratified facies with very continuous medium-amplitude and high-frequency reflections (Fig. 8A, 9). This facies shows truncated reflectors towards the Zambezi Valley and a convergent internal configuration away from the valley axis (Fig 8A, 14A), similar to well-known levees of channel-levee systems (e.g. Congo, Amazon, Indus, Mississippi). We therefore interpret this facies as fine-grained overbank turbidites (probably alternating with very fine hemipelagic deposits). The stacking of these turbidites resulted in a ca. 0.7 stwt ( $700 \mathrm{~m}$ ) thick seismic unit (up to $0.9 \mathrm{stwt}, \sim 900 \mathrm{~m}$, locally) (Fig. 10D). Smaller units of inferred coarse-grained turbiditic (Uf, see Fig. 9 and section hereafter) and MTD (Ug, see Fig. 9 and section hereafter) origin are intercalated locally within U4. In addition, towards the east, lateral change in facies and external configuration to wavy parallel reflections (Figs. $8 \mathrm{~A}, 14 \mathrm{~B}$ ) suggest a possible contemporaneous contouritic sedimentation on the Madagascar slope and along the Davie Ridge (Fig. 13B). This transition is arbitrary since there is probably a complete gradation between turbiditic and contouritic deposits. 

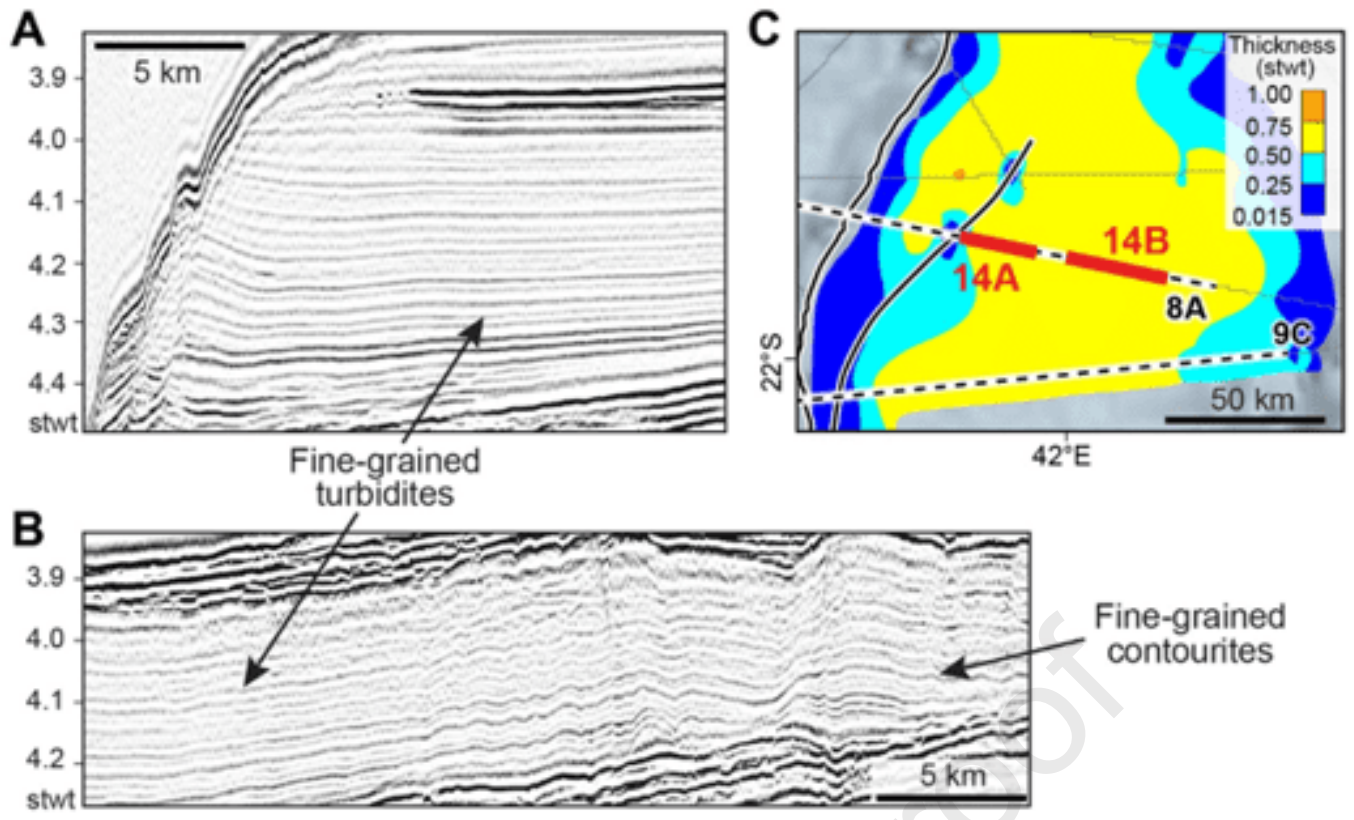

540 Figure 14: Close up of unit U4 that characterizes the left (looking downstream) border of the

541 Zambezi Valley. (A): Detail on fine-grained turbidites close to the Zambezi Valley, with

542 truncated reflectors towards the valley and convergent internal configuration away from the

543 valley axis. (B): More distally from the valley, a lateral change in facies to a wavy

544 configuration suggests mixed turbidite-contourite deposits. (C): Zoom of the distribution and

545 isochore map of unit $U 4$ with the location of seismic profiles $A$ and $B$.

Unit U5: Ponded turbidites confined in the Intermediate Basin

Unit U5 is wedge-shaped (Fig. 15) and consists in two main depocenters up to 1.6 stwt $(\sim 1600 \mathrm{~m})$ thick (Fig. 10E) along the Mozambique base of slope. It shows numerous small incisions inside it evoking erosional channels and is composed of seismic sub-units that migrate alternately to the NE and SW (Fig. 16D) indicating shifts of depocenters over time.

553 The main core of unit U5, between the Mozambique slope and the lles Eparses, is composed

554 of an alternation of high-amplitude facies (probably coarse-grained turbidites) and more

555 transparent or even chaotic levels (respectively small but recurrent MTDs and erosional channels) that suggest a cyclic sedimentation (Fig. 16). The base of U5 shows large irregular undulations (erosional structures?) (Figs. 15, 16A) where contourites (possibly related to the 
558 Neogene drift proposed by Raisson et al., 2016) are suspected to be affected by structural 559 doming (Fig. 8).

560 In its distal most part, between the lles Eparses and the Zambezi Valley (Fig. 8A), unit U5 561 appears as an infilling unit composed of continuous, strong amplitude and low frequency 562 reflections with onlapping terminations (facies S2, Figs. 6, 8A) on the supposed contourite 563 drift (Fig. 17).

564

565 In the center part of the Intermediate Basin near the lles Eparses, a transparent cover rests 566 unconformably on the turbiditic deposits (Figs. 16). On sub-bottom profiles, this cover reveals 567 continuous, high frequency reflections with increasing amplitude towards the top (Fig. 16C).

568 These characteristics at the top of the cover suggest an increase in coarse-grained material

569 in the youngest strata. This cover has a variable thickness (ca. 0-100 m) and a limited

570 distribution area. Owing to these characteristics, we suggest that this cover consists of an

571 alternation of contourites or fine-grained turbidites with hemipelagic sediments. Any firm

572 attribution of this superficial cover would need ground truthing by coring.

573 


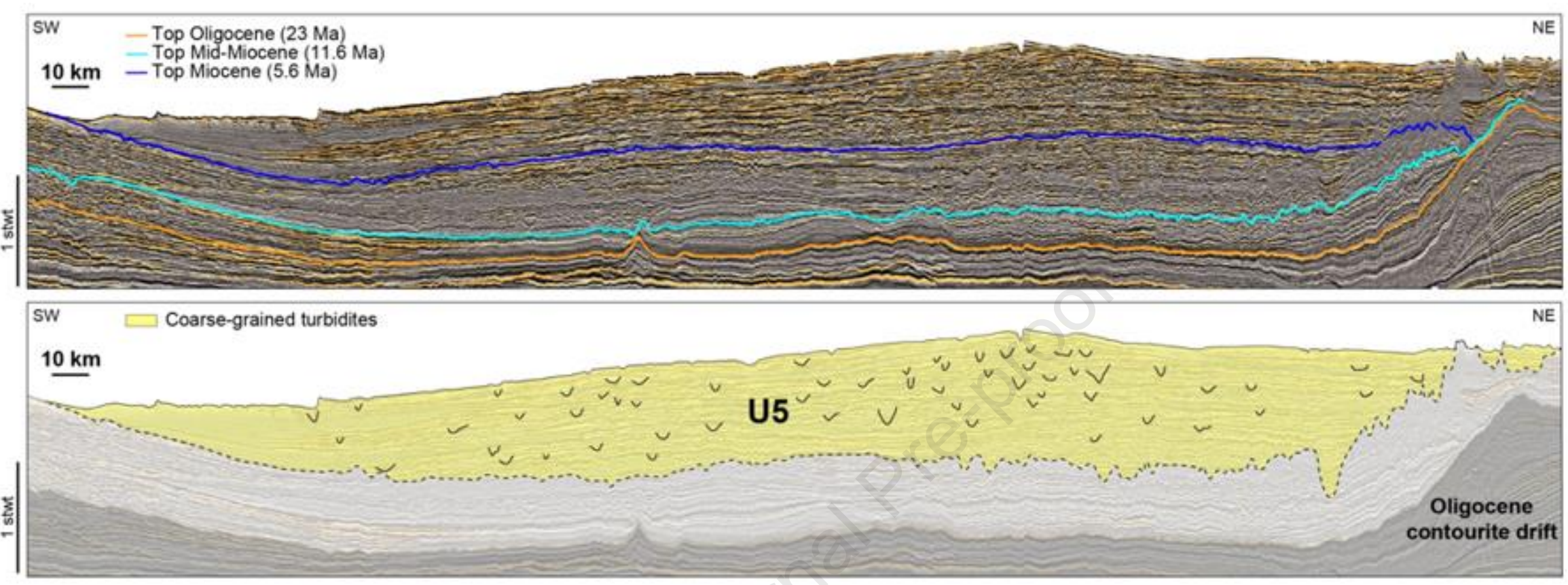

Figure 15: The architecture of the Ponded Fan. (A) NW-SE seismic section with stratigraphy established by Ponte (2018) and (B) corresponding line drawing with indication of facies, crossing the Intermediate Basin (modified from Thiéblemont et al., 2020, data image courtesy of INP and

WesternGeco). The Ponded Fan (infilled by mainly coarse-grained turbidites) is cut by several small incisions (black V forms in B). The position of the profile is shown in Fig. 10E. 


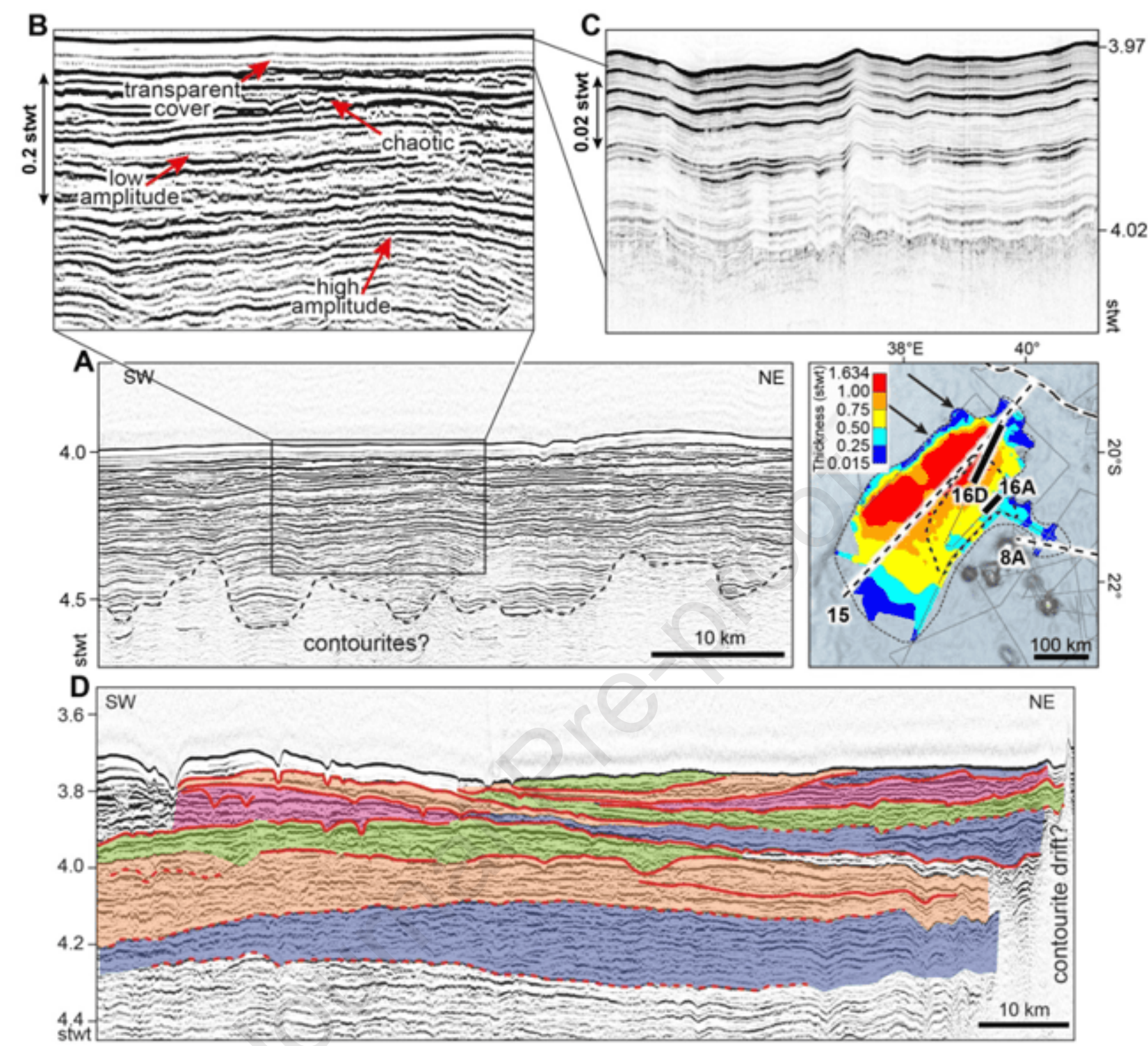

580 Figure 16: Detail of unit U5 that characterizes the infill of the Intermediate Basin. (A): High-

581 resolution multichannel seismic profile (MOZ4-SR-173) showing the continuous, strong

582 amplitude reflections with low frequency alternating with transparent and chaotic facies. The

583 base of the U5 is delineated by a dashed line. (B): Zoom of $A$ that shows more in detail the

584 vertical variations in amplitude. (C): Transparent cover on a sub-bottom profile (MOZ4-SDS-

$585173 d$ and e with alternating highly stratified facies in uppermost section). (D): Migrations of

586 the depocenters characterizing the filling of the Intermediate Basin (line MOZ4-SR-171a and

587 b). Colors are only used to highlight shifts in seismic units (no particular lithological

588 significance). Note also the decrease in the thickness of the transparent surface layer, until it

589 disappears towards the NE. At its NE limit U5 is onlapping on a contourite drift (Raisson et 
A

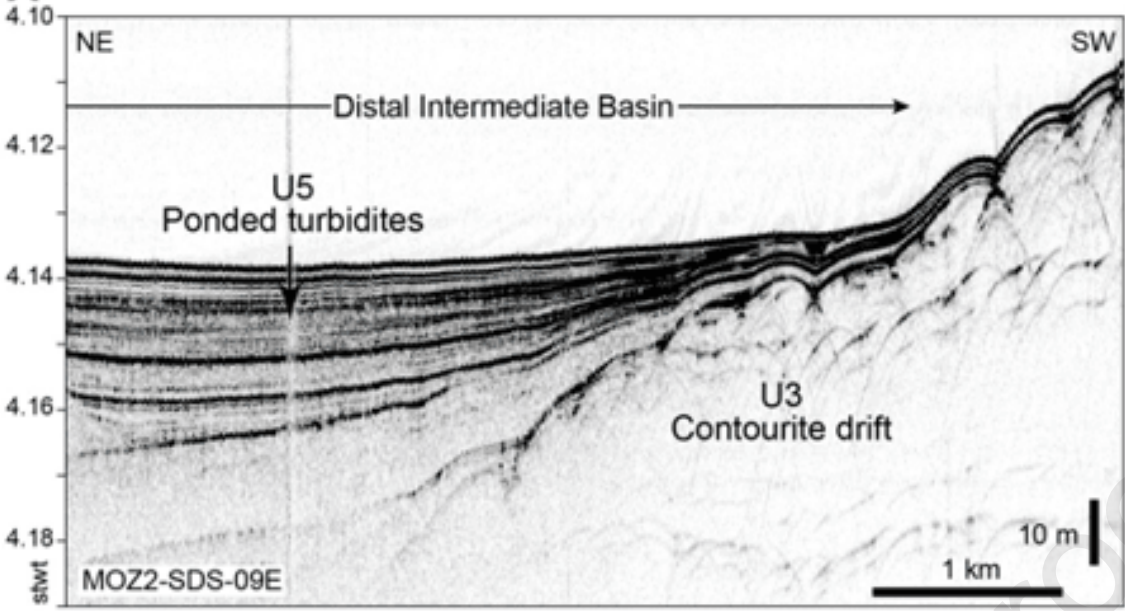

B $\quad 40^{\circ} \mathrm{E}$

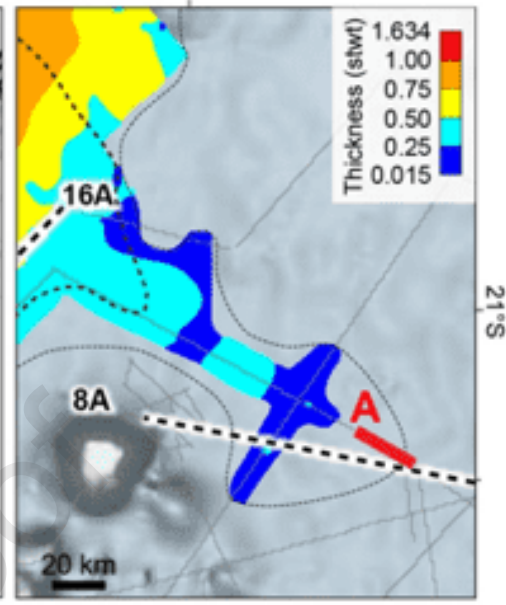

592

593

594

595

596

597

598

599

600

601

602

603

604

605

606

607

608

609

610

Figure 17: The distal end of unit U5 (Ponded Fan). (A): Sub-bottom profile illustrating the onlapping terminations on unit U3 (modified from Fierens et al., 2020). (B): Zoom of the distribution and isochore map of unit U5 (see Fig. 10E) showing the location of the subbottom profile $\mathrm{A}$.

\subsubsection{Stratigraphy of the seismic units}

The regional stratigraphic framework of the Mozambique Channel and Zambezi turbidite system (Fig. 4) established by Ponte (2018) allowed us to assign ages for the deposition of seismic units (Fig. 8). Units U1 and U2 were deposited during the Oligocene (between Top Eocene and Top Oligocene horizons) and Early Miocene (between Top Oligocene and Top Mid-Miocene horizon) respectively. Units U3 to U5 are Plio-Quaternary in age (deposited above the Top Miocene horizon). Because of the lack of stratigraphic information on both sides of the valley and because units U3 and U4 are separated by the deeply incised Zambezi Valley, the precise timing of deposition of these units and the stratigraphic continuity of their sedimentary successions are unknown (synchronous or alternative, continuous or discontinuous deposition?). Unit 5 corresponds in profile A of Fig. 8 to the distal part of the Ponded Fan. The main depocenter of U5 is developed updip of the lles Eparses. Downdip the islands, unit U5 onlaps on unit U3 and appears to have been 
611

612

613

614

615

616

617

618

619

620

621

622

623

624

625

626

627

628

629

630

631

632

633

634

deposited late (Late Quaternary?). According to this stratigraphic framework, the Miocene interval and especially the Late Miocene are very thin (only some hundreds of meters in Fig. 8A).

In the distal depositional area (DA), the timing of deposition is different from upstream: turbidite facies are absent during the Oligocene and only began to deposit during the Miocene. It must also be noticed also that contrarily to upstream, the Miocene deposits (especially the Late Miocene) are much thicker.

\subsubsection{The Zambezi Valley incisions}

While the Oligocene, the Early Miocene and the Plio-Quaternary periods were dominantly characterized by thick aggrading deposits, the Late Miocene period is distinguished by a limited turbiditic deposition (Fig. 8A) and a deep entrenchment of the valley.

The Zambezi Valley is currently deeply incised with relief exceeding $700 \mathrm{~m}$ in the middle portion of the valley (Fierens et al., 2019). It evolved during the Miocene through several phases of incision and infilling (Figs. 18, 19), some of them observed continuously all along the Zambezi Valley. Three main incisions, namely Angoche2 (A2), Zambezi1 (Z1) and Zambezi2 (Z2) from the oldest to the youngest (Figs. 9, 18, 19) are identified. Additionally, a fourth incision (Zambezi3, Z3) corresponds to very recent erosion, well expressed on bathymetric data of the valley floor (Fierens et al., 2019). Besides some local shifts that may be observed (e.g., profile 7, Fig. 18 and profile 13, Fig. 19), A2, Z1 and Z2 occur mostly vertically under the current Zambezi Valley, indicating that this valley did not undergo major migration since its formation. Multiple additional minor erosional unconformities inside the valley and in the depositional area (purple unconformities in Fig. 19) are observed but cannot be followed from upstream to downstream. 

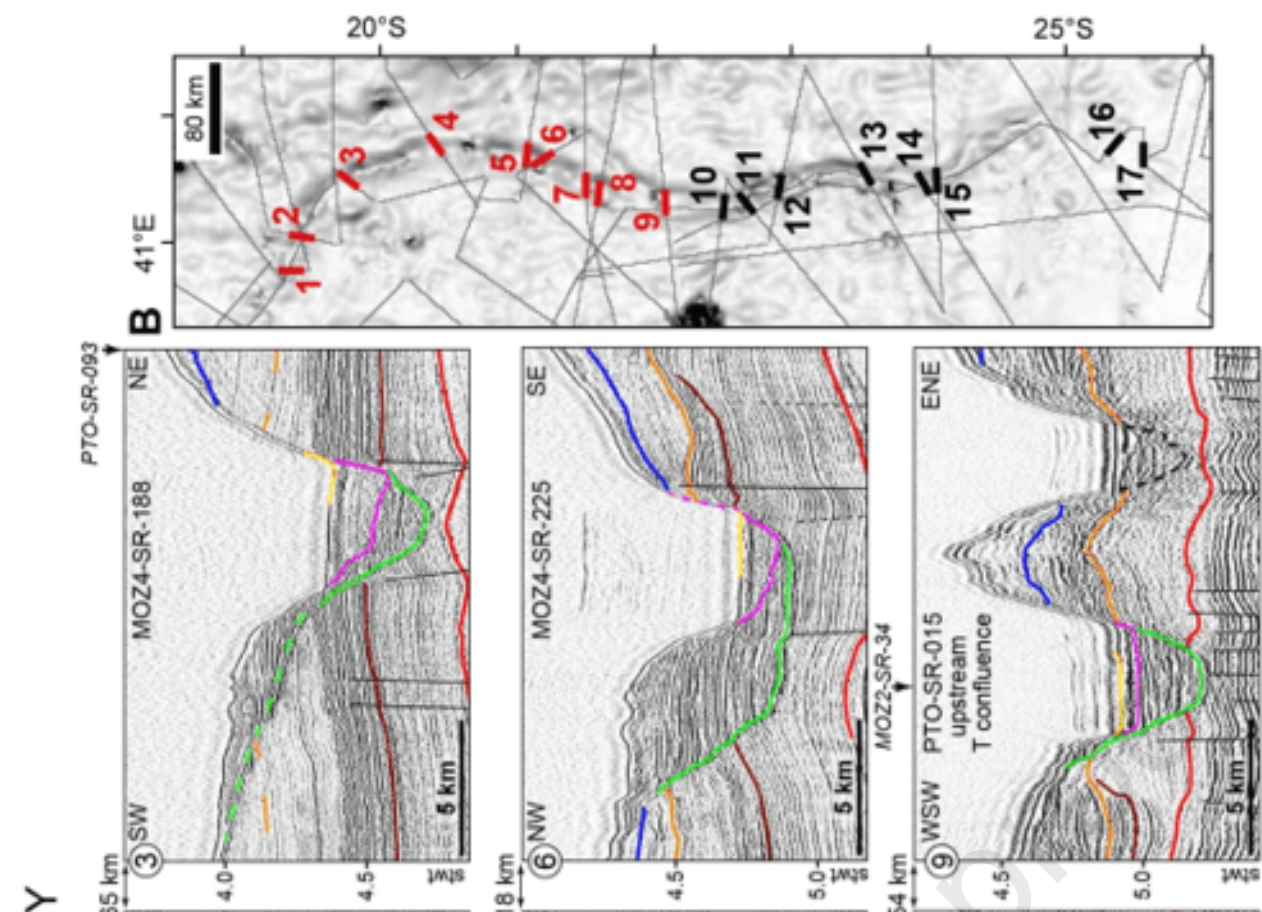

กิ $\sum_{0}^{\pi}$

है เ

峞
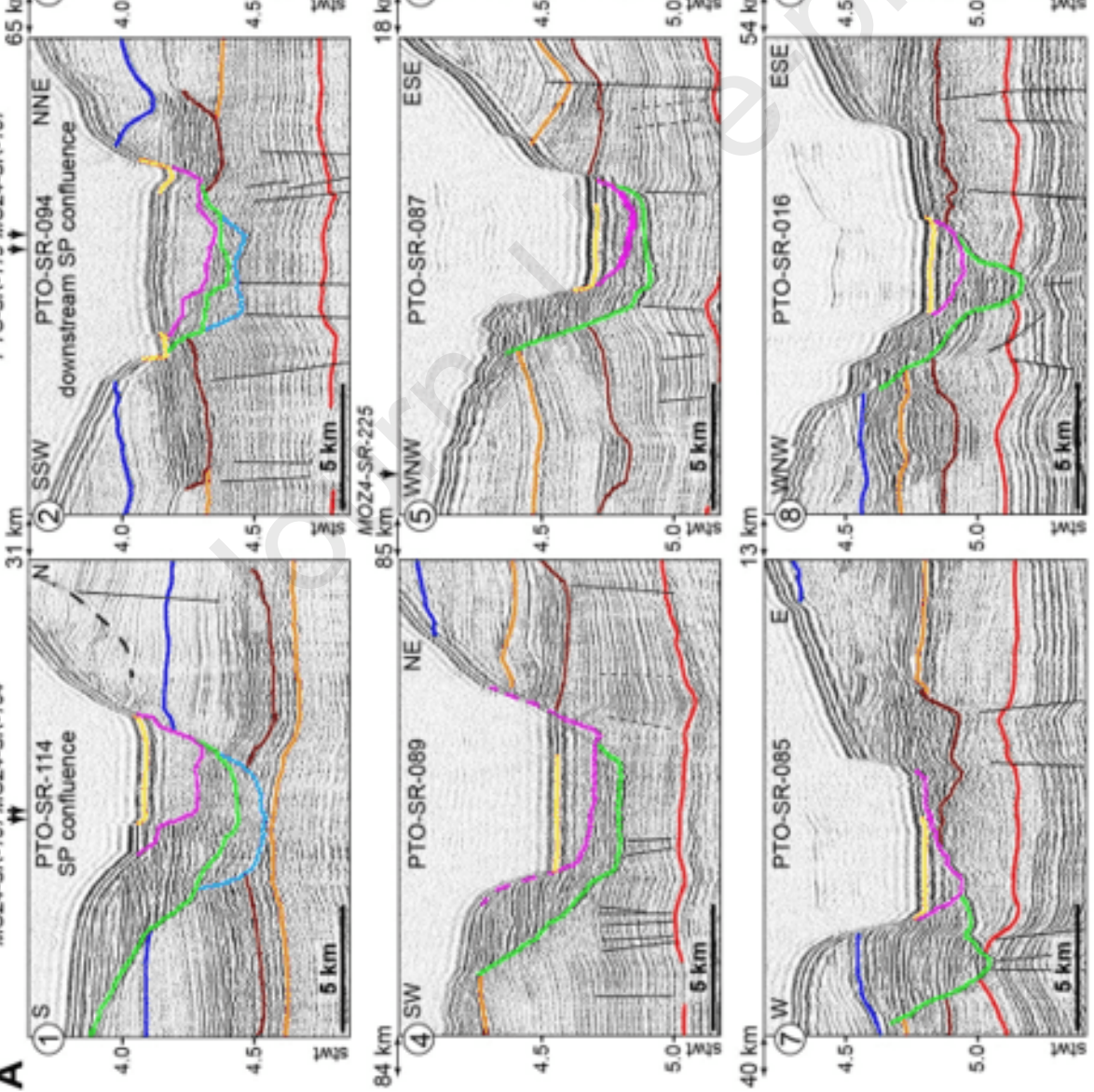

N

N

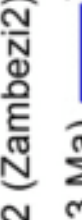

ก กับ

|

흥

๑

틍 음

N

$\bar{N}$
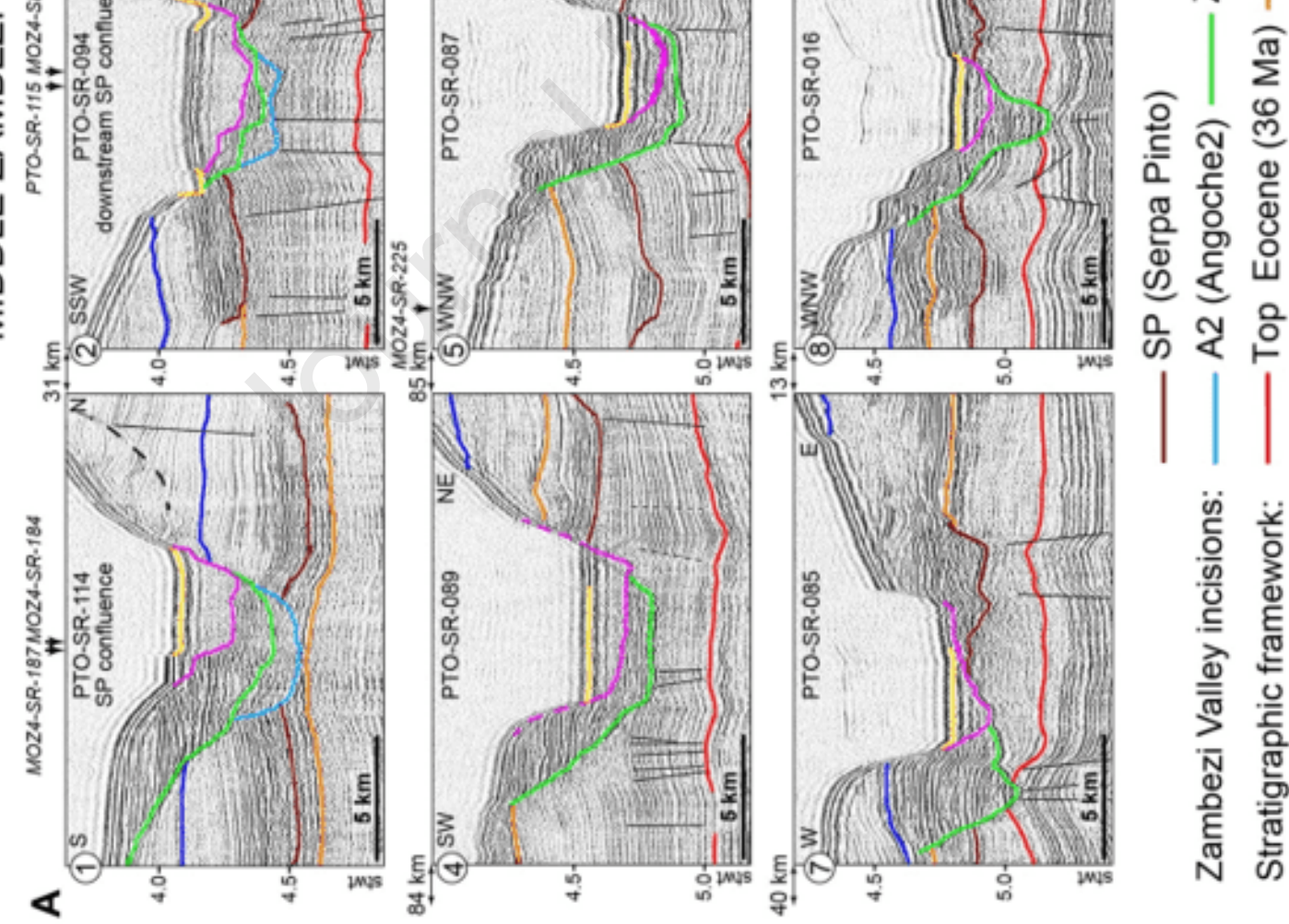

Figures 18: Upstream-downstream evolution of the incisions in the Zambezi Valley upstream of the confluence with the Tsiribihina Valley. Serie of seismic profiles $(A)$ : located as red lines on the Gebco slope map (B). Vertical black lines and black arrows in A are faults and profile crossings, respectively. The incision of the Tsiribihina Valley (not studied in this paper) is 
641 supplementary material B-1.
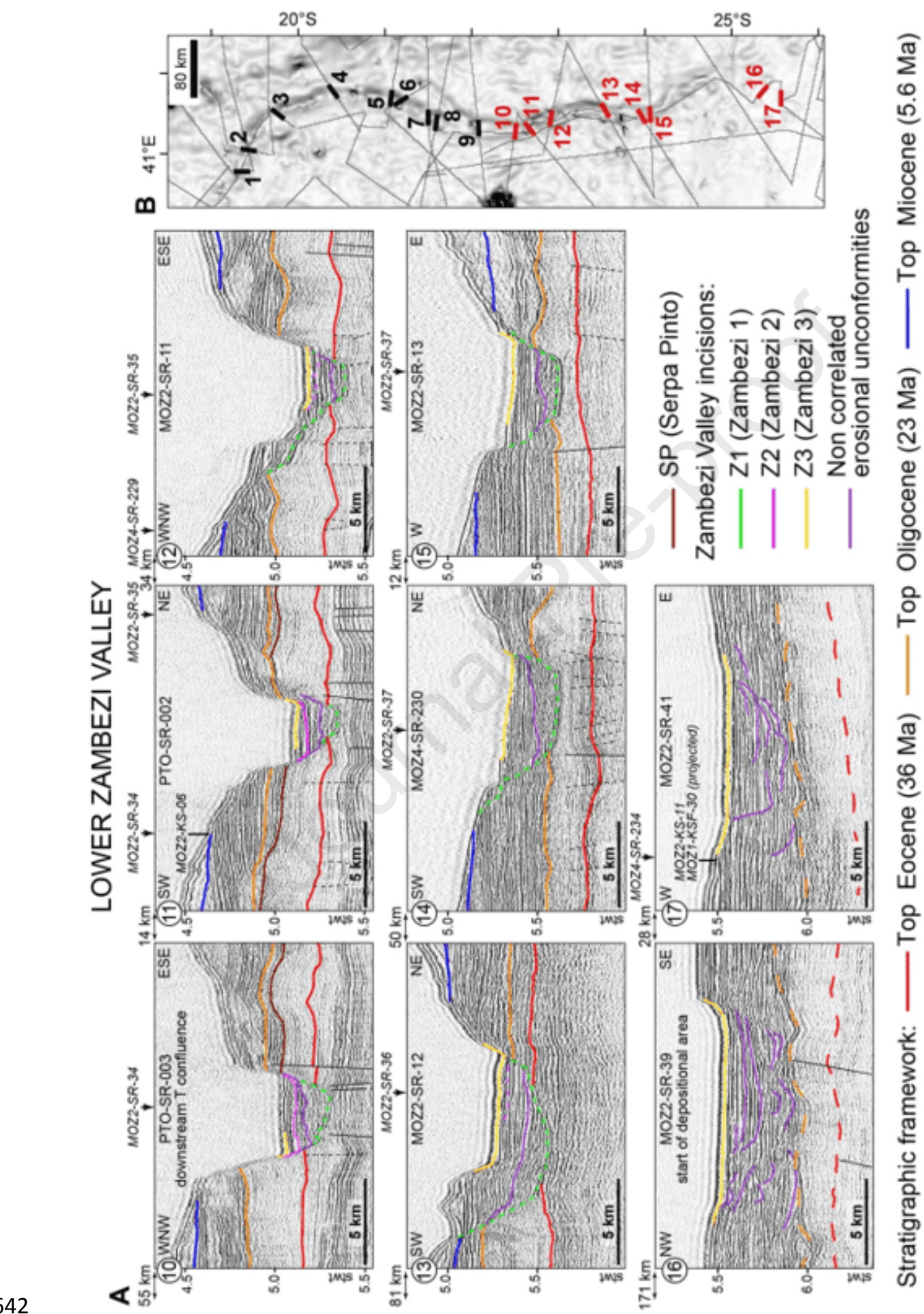

642

Figure 19: Upstream-downstream evolution of the incisions in the Zambezi Valley

644 downstream of the confluence with the Tsiribihina Valley. Serie of seismic profiles (A) located 
as red lines on the Gebco slope map (B). Vertical black lines and black arrows in A are faults and profile crossings, respectively. Uninterpreted seismic profiles are provided as supplementary material B-2.

\section{A2: Beginning of over-deepening of the Zambezi Valley}

Incision A2 is the deepest incision observed on available seismic data. It is recognized only in the upstream portion of the Zambezi Valley, not far upstream from the Angoche ValleyZambezi Valley confluence (Fig. 18 profile 1). A2 is therefore thought to relate to the Angoche Valley. This incision disappears rapidly downstream because of its erosion by the following incision Z1 (Fig. 18).

As proposed above, the Angoche Valley may have contributed to the feeding of the fan simultaneously with the Serpa Pinto Valley during an initial stage of activity (Angoche1, Fig. 9A). A2 is the trace of the latest incision by the Angoche Valley, when the Serpa Pinto Valley was no longer active. It implies that the Angoche Valley probably deeply incised during its second stage of activity, resulting in the total disappearance of the previous A1 erosional course (Fig. 18, profile 1, 2).

\section{Z1: Main incision resulting in the first occurrence of the upstream part of the Zambezi}

\section{Valley}

Incision Z1 is identified upstream from the Angoche Valley confluence. Consequently, it is considered to indicate the first occurrence of the valley that funneled the inputs of the Zambezi River. It marks the definitive installation of the valley at its present-day position on the central Mozambique margin.

Z1 eroded down to the upper strata of the Eocene sequence (Fig. 18). It is identified all along the Zambezi Valley (Figs. 18, 19). The depth below the current valley floor evolves irregularly from up to $\sim 0.4$ stwt (profiles 1 and 8 , Fig. 18) to down to $\sim 0.2$ stwt (profile 6, Fig. 18), and the depth below sea level varies from 4.4 stwt (profile 1, Fig. 18) to 5.6 stwt on profile 15 (Fig. 19) where it is tentatively identified. 
673 Its infill is very thick (more than 0.4 stwt, $~ 400 \mathrm{~m}$, on profiles 4 to 6 , Fig. 18) and is generally

674 made of high-amplitude stratified facies indicating coarse-grained material, with facies that

675 vary on profiles from chaotic to transparent to stratified (Fig. 18, 19).

676

Z2 and Z3: later incisions of the Zambezi Valley

Incision Z2 is the last main incision of the Zambezi Valley. Its infill is characterized by a 0.2 stwt ( 200 m) thick transparent body, identified continuously from the upper reaches of the

680

681

682

683

684

685

686

687

688

689

690

691

692

693

694

695

696

697

698

valley to about $100 \mathrm{~km}$ southwards of the Tsiribihina confluence. This transparent mass is interpreted as a mass transport deposit (MTD). Above the MTD, a thin layer (at the seismic scale) of sediments is observed, mostly in the upstream portion of the valley.

Erosion Z3 is observed all along the Zambezi Valley and represents the youngest erosional events. Compared to previous incision events, this erosive period appears rather negligible. It resulted in local over-deepening of the valley floor up to 0.063 stwt ( $63 \mathrm{~m})$ (profiles 1-2, Fig. 18) and gave the valley its current morphology (see Fierens et al., 2019).

\section{DISCUSSION}

\subsection{Origin of depositional units}

\section{U1: Serpa Pinto channel-levee complex with possible first stage of Angoche Valley}

As mentioned previously (Section 4.2.3) unit U1 deposits are related to the Serpa Pinto Valley. The Serpa Pinto Valley received inputs from the northern part of Mozambique (Lurio and probably other northeastern African drainage basins, Ponte, 2018), indicating a $1100 \mathrm{~km}$ long transfer of sediments downstream to the most distal area where the channel-levee complex is identified with certainty (Figs. 9E, 10A). Moreover, in the northernmost part of the study area (Fig. 9A), overbank deposition is observed from both the Serpa Pinto and the Angoche Valley. This indicates that there was possibly a contemporaneous first stage of Angoche Valley (Angoche1, Fig. 9) that contributed to the channel-levee complex. 
699

700

701

702

703

704

705

706

707

708

709

The U1 channel-levee complex, which was deposited during the Oligocene, is coeval to the building of the Zambezi giant 1.8 stwt-thick contourite drift on the southern bank of the upper Zambezi Valley (Fig 1B, 20A) (Raisson et al., 2016; Ponte, 2018; Thiéblemont et al., 2020). The juxtaposition of 2 major sedimentation mechanisms raises the question of their possible interaction. It is probable that the dramatic increase in terrigenous sedimentation brought into the basin by valleys (Ponte, 2018), associated with the major modification of global oceanic circulation (Ponte, 2018; Thiéblemont et al., 2020) controls the construction of the giant drift. It is noticeable that the giant drift builds approximately where the northeastward flowing deep waters were interpreted to turn back to the South (Thiéblemont et al., 2020).

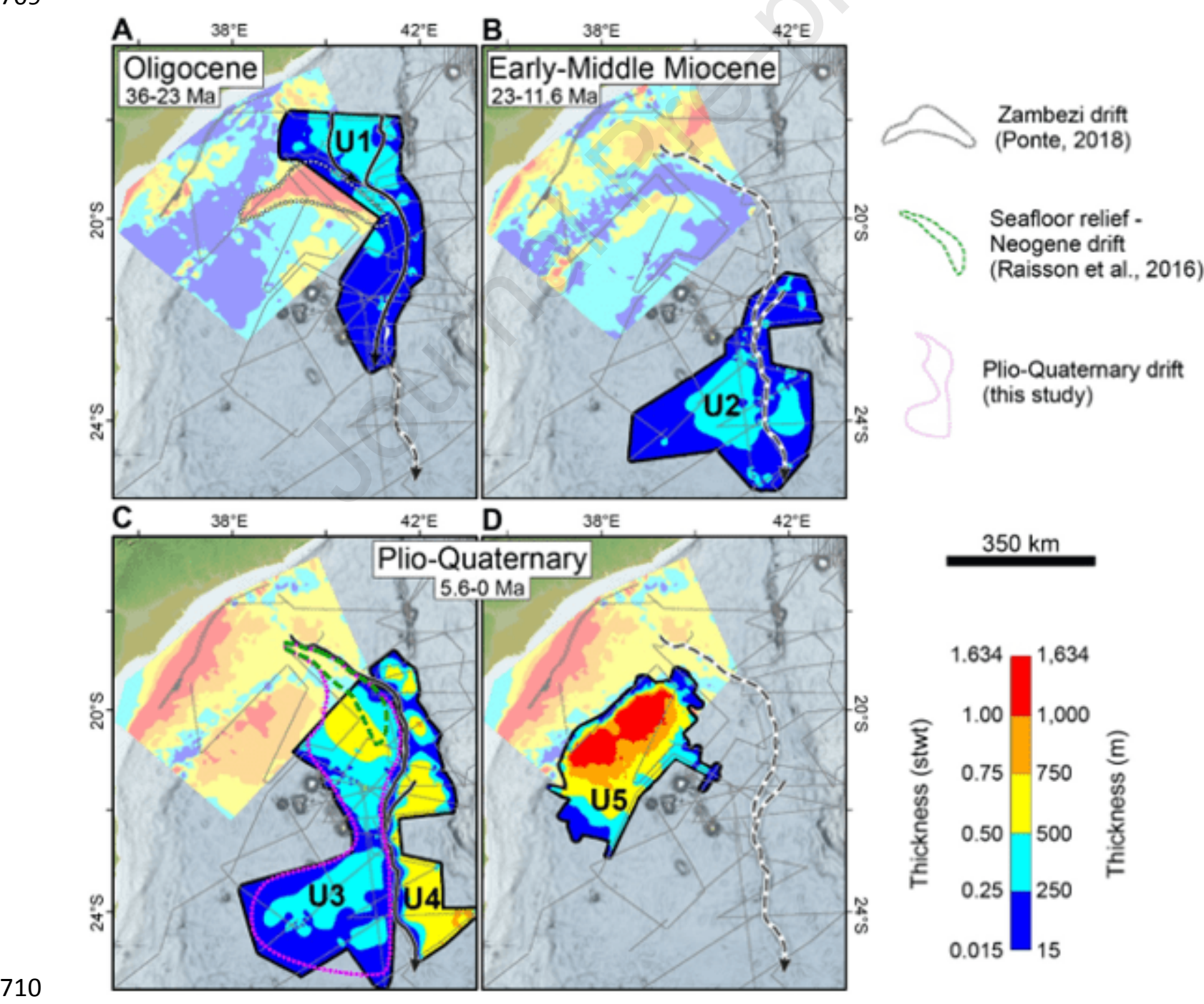


Figure 20: Composite thickness maps including the Zambezi turbidite system (this study)

712

713

714

715

716

717

718

719

720

721

722

723

724 (surrounded with a black line) and the upper Mozambique margin (Ponte, 2018). The different contouritic drifts identified are indicated: $(A)$ : Oligocene sediment thickness (36-23 $\mathrm{Ma})$; (B): Early-Middle Miocene sediment thickness (23-11.6 Ma); (C) and (D): PlioQuaternary sediment thickness (5.6 Ma-0 Ma). See Fig. 10 for key to understand of black arrowed lines.

\section{U2: Serpa Pinto (or Madagascar) Lobe complex}

With the available data, it was not possible to define the upstream extension of unit U2 and therefore the origin of unit U2 could not be properly established. The NE-SW orientation of U2 deposits suggests two possible origins: from the Madagascar margin (paleo-Tsiribihina Valley) or from the Serpa Pinto Valley (with or without the Angoche Valley). However, Delaunay (2018) stated that the overspill of Madagascar inputs to the Zambezi system occurred only from Middle Miocene, when the Morondova Basin was infilled and detrital sediments from Madagascar could overcome the Davie Ridge. The hypothesis of a Madagascan origin of unit U2 appears therefore less convenient and thus a persistent feeding by the Serpa Pinto Valley (or by the combined Serpa Pinto + Angoche valleys) is favored.

\section{U3-U4: Mixed contouritic-turbiditic sedimentation}

Units U3 and U4 have been described separately because we do not have any stratigraphic information to give a relative chronology. However, owing to the top Miocene horizon of Ponte (2018), they were both deposited during the Plio-Quaternary, and we think that they were probably contemporaneous.

Unit U3, identified as a contourite drift at a water depth of ca. 2800 to $3500 \mathrm{~m}$, may have been generated by bottom currents associated to the northward flowing Mozambique Undercurrent, which contain the North Atlantic Deep Water (NADW) at this particular depth range (van Aken et al., 2004). This interpretation is consistent with the observation of Miramontes et al. (2019) that the present-day NADW partly flows inside the Zambezi Valley 
and contribute to the flank erosion and over-widening of the valley. This large contourite drift which developed on the southern bank of the upper Zambezi Valley, just where it bends from a NW-SE to N-S trend (pink dotted polygon in Fig. 20C), is shifted to the SE with regard to the giant Oligocene drift (Fig 20A) and extends more to the SW. The Plio-Quaternary contouritic drift is associated to a sea floor relief (green polygon in Fig 20C) that was formerly called Neogene drift by Raisson et al. (2016). Here again we can suppose that the drift benefited from the terrigenous supply of turbidity current overflows (by possible sediment pirating) whose origin is not clear (as it can come from turbidity currents from the Zambezi Valley and/or distal sediment upwelling to the north).

On the left border of the Zambezi Valley and both sides of the Tsiribihina Valley fine-grained levee turbidites dominate (Fig. 8A, 9B-C). The U4 deposit thus indicates that there is a synchronicity of different terrigenous input sources coming from the Mozambique and Madagascar margins. Moreover, the lenticular units Uf and Ug (present in the upper part of unit U4) attest to recurrent inputs from Madagascar that are not funneled into the Tsiribihina Valley. In addition, contourites appear to have been constantly deposited, either synchronously or in alternation with levee deposition, especially in areas approaching high reliefs, such as the Davie Ridge (Fig. 13B).

\section{U5: Ponded turbidites from the Mozambique slope}

The mainly coarse-grained turbidites were fed to the Intermediate Basin through a network of parallel valleys originating from the Mozambique slope off the Zambezi River mouth (Fig. 7A). Several channels have been identified, however the density of channels on the slope is rather small (ca. $50 \mathrm{~km}$ between each main channel). These valleys disappear halfway up the slope in agreement with the absence of canyons on the highest part of the slope (Jouet and Deville, 2015), demonstrating that there is no current connection between the shelf and the basin (as it was also observed for the Zambezi Valley). Wiles et al. (2017b) showed that channels in the southwestern portion of the basin (see Fig. 1B) probably transfer some of the Zambezi inputs towards the Bourcart-Hall Depression southeast of the lles Eparses. 
765 Based on the stratigraphy of Ponte (2018), the Intermediate Basin began to fill in during the 766 Upper Miocene, while deposition had mainly ceased in the Zambezi Fan that was mainly

767 subject to erosion inside the valley (see Section 5.2), except in the distal depositional area.

768 This is the only period of time during which data highlight a clear absence of synchronicity 769 between both turbidite accumulation sites of the Mozambique margin. Later on, during the 770 Plio-Quaternary, the Intermediate Basin was filled in and sediment deposition happened in 771 the Zambezi Fan.

772 The thickness map (Fig. 10E) is consistent with that of Thiéblemont et al. (2020) (Fig. 20D).

\subsection{Upstream-downstream evolution of the incisions and effects of the Miocene} doming

776

777 The depth profiles of incisions A2 to Z2 (Fig. 21B) show that A2 and Z1 incisions suffered a 778 post-depositional deformation. This deformation is well expressed by the depth profiles of 779 Top Eocene and Top Oligocene horizons observed between km 100 and km 900. It was described by Ponte (2018) as an episode of doming during the Miocene (Fig. 21C). 


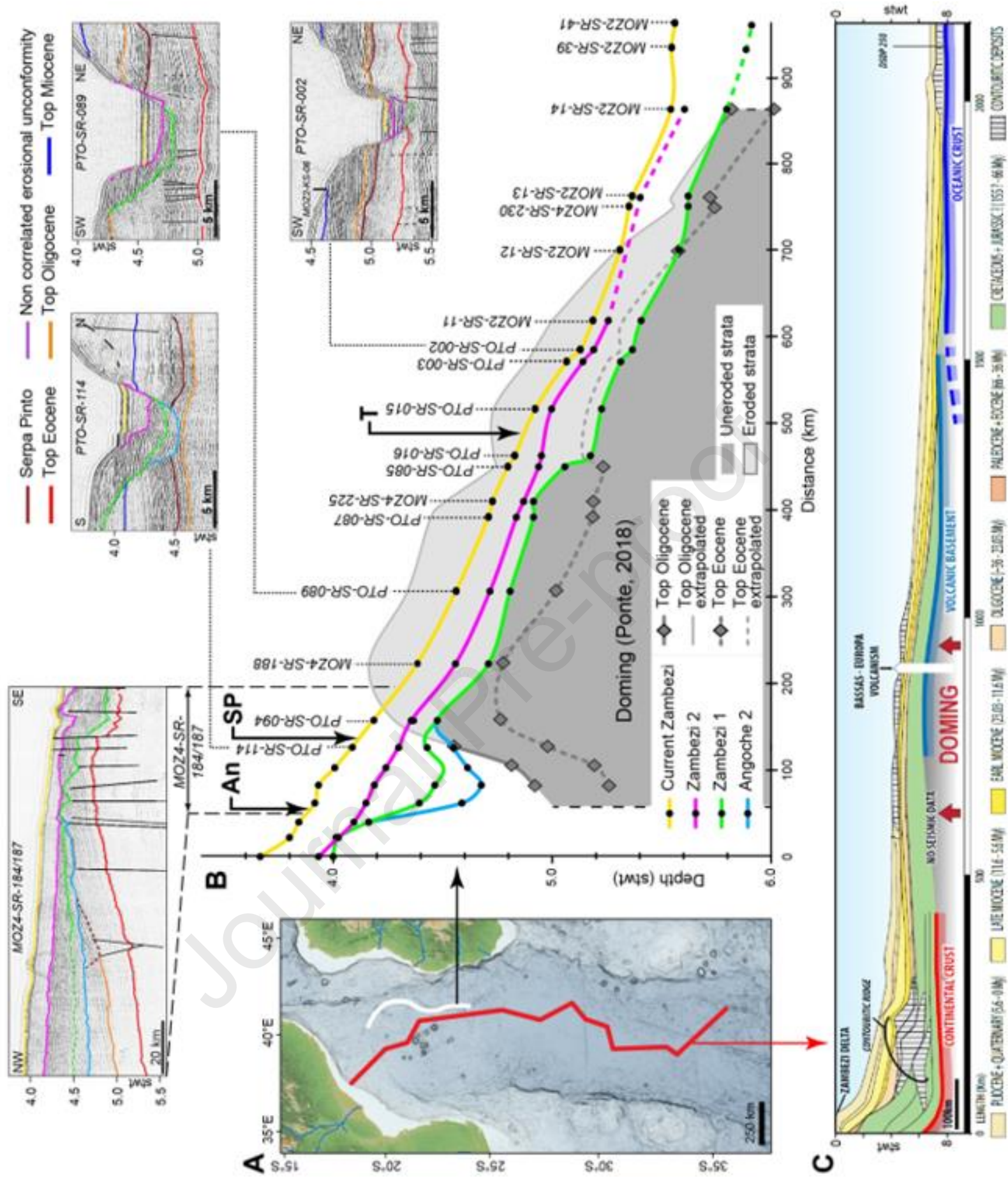

783 Figure 21: Effects of the Miocene doming in the central Mozambique Channel on the

784 Zambezi Valley incisions. (A) Position of profiles shown in B (white line) and C (red line). (B)

785 Depth profiles (in stwt) of the main incisions. An, SP and T: Angoche, Serpa Pinto and

786 Tsiribihina confluences, respectively. The depth profiles of the Top Eocene and Top

787 Oligocene horizons are reconstructed from Ponte (2018). (C) Synthetic dip profile of the

Mozambique Channel showing the Miocene doming (Ponte, 2018). 
790

791

792

793

794

795

796

797

798

799

800

801

802

803

804

805

806

807

808

809

810

811

812

813

814

815

816

The deformation of A2 and Z1 incision profiles (MOZ4-SR-184/187 in Fig. 21B from around 50 to $150 \mathrm{~km}$ ) and of the Top Eocene and Top Oligocene horizons indicate that the deformation began after the initial incision of $\mathrm{A} 2$ and $\mathrm{Z} 1$ axes and was prolonged during their activity. This allows dating the A2 and Z1 incisions before the start of the doming deformation in Middle Miocene (Ponte, 2018). On the other hand, we also observe locally the preservation of the Top Oligocene reflector below the A2 incision (see profile PTO-SR-114 on Figs. 18 and 21), so A2 and Z1 are also post-Top Oligocene. The following Z2 and Z3 incisions are not affected by the deformation and have depth profiles close to an equilibrium state. The incision of Z2 happened therefore after the end of doming deformation in Late Miocene according to Ponte (2018).

The continuous deformation resulted in a constant adjustment of the $Z 1$ incision depth profile by entrenchment in order to compensate the uplift movement and to establish a new equilibrium state. The deep entrenchment of $\mathrm{Z1}$ incision resulted in the erosion and disappearance of $\mathrm{A} 2$ (and probably also A1). The Z1 depth profile is not at an equilibrium state, it is assumed that it was abandoned prematurely before it had time to reestablish a full equilibrium profile.

The structural deformation on the Zambezi Valley during the Miocene had significant influence on the capacity to transfer sediments downstream. The continuous erosion in link with the elevation of the seafloor during the Miocene resulted in an over-incision of the Z1 incision, the production of important volumes of reworked sediments and the absence of levee deposits related to over-deepening of the valley floor.

The lacking, eroded Oligocene strata are estimated to a minimum of 0.4 stwt thickness ( 400 m) and occur at least along $700 \mathrm{~km}$ (from profile PTO-SR-094 to profile MOZ2-SR-13, Fig. 21B). If the shape of the $\mathrm{Z1}$ incision is approximated by a half rectangular prism of ca. 700 km long, $400 \mathrm{~m}$ high and $4 \mathrm{~km}$ wide (mean wideness of Zambezi1 incision, see Fig.18), a rough minimum volume of $560 \mathrm{~km}^{3}$ of eroded sediments is estimated. This reworked 
sedimentary volume is probably deposited downstream. At the time the incision occurred, it was unrelated to input by the Zambezi and other feeding rivers and therefore should be taken into consideration for the erosion-sedimentation balance calculations in source to sink studies. Conversely, the upstream portion of the Z1 incision (Fig. 21B, from km 50 to 150) shows a concave upward-shape suggesting that it could have served as a trap for the Zambezi River inputs. This would have decreased the sedimentary volume able to reach the deeper portions of the Zambezi Fan. However, it can be assumed that the volume of trapped sediments inside $\mathrm{Z1}$ is negligible with regards to the eroded Oligocene strata volumes (from km 150 to $\mathrm{km} 850$, Fig. 21B).

\subsection{Distinct modifications in the Zambezi turbidite system development}

The Zambezi turbidite system experienced drastic modifications of sediment deposition during its evolution. Since Oligocene, sediment feeding axes migrated westward for the upstream portion of the Zambezi Valley (from SP-A1 to A2 to Z1-Z3) and a general southward migration of deposits happened. This was partly accompanied by successive variations in sedimentological regimes alternating between mainly aggradational and erosional phases (Fig. 22).

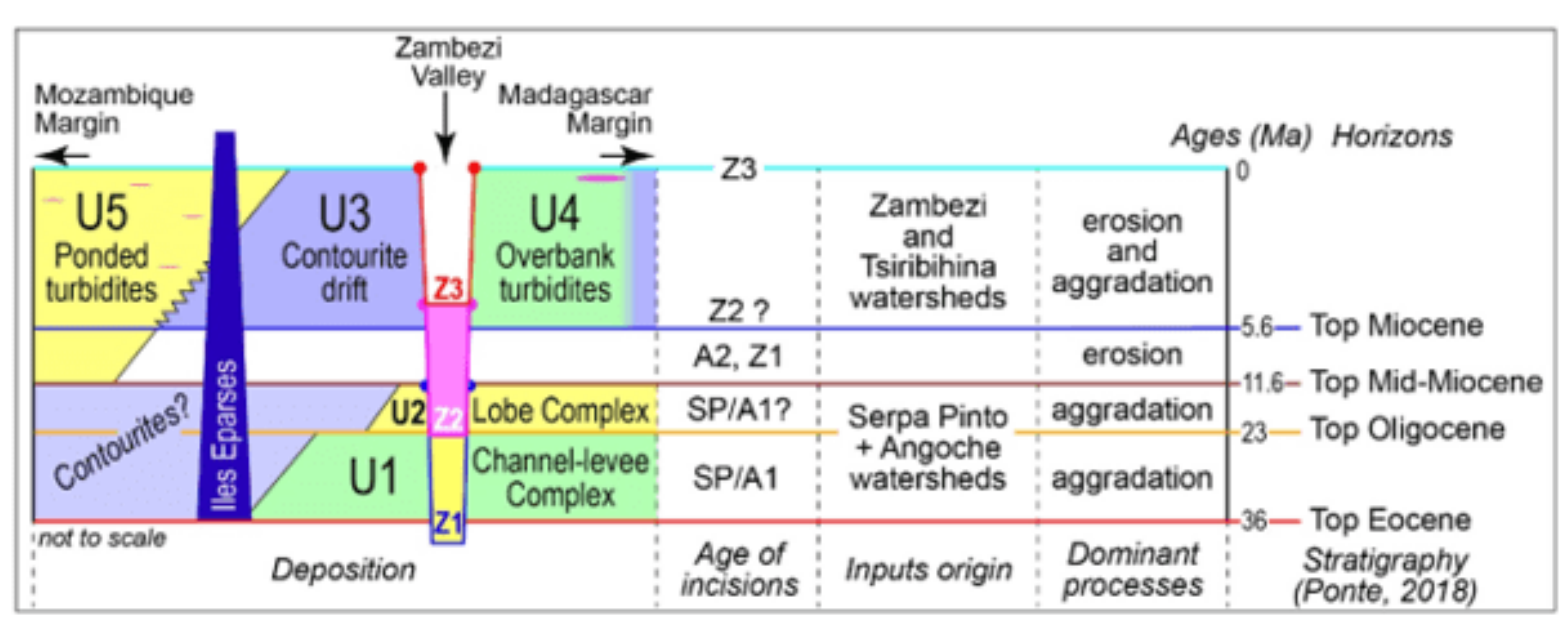

Figure 22: West-east schematic illustration of the timing of seismic unit deposition and main incisions for the Zambezi turbidite system based on the stratigraphy established by Ponte 
838 (2018). Green: fine-grained turbidites; Yellow: coarse-grained turbidites; Blue: contouritic

839 deposition; Pink: mass-transport deposit.

840

841 The Oligocene was dominated by mainly fine-grained deposits and aggradational processes

842 with the deposition of the Serpa Pinto channel-levee complex (U1). Limited erosional processes were restricted to the basal surface of the channel and it was possibly combined with a first stage of Angoche Valley activity (Fig. 9A). The deposition evolved during Early Miocene into coarse-grained sediments that are interpreted as distal turbiditic channel-mouth deposits of the Serpa Pinto system (U2). Their installation on previous more proximal channel-levees could reflect the retrogradation of the system. The origin of the change in depositional regime and possible retrogradation is unknown, but is probably related to the offshore tectonic deformation in the eastern branch of the East African Rift (Courgeon et al., 2018), which would provoke changes in sediment flux supplied from North Mozambique. The thickness map of Miocene sediments (Fig. 20B) shows that deposition started in the Intermediate Basin, while the Zambezi Fan is dominated by erosional processes during Middle to Late Miocene. This with two successive incisions (A2 and Z1) that indicate a shift of the position of the source, from the Angoche to the Zambezi drainage basin. In the Late Miocene, the incisions were affected by a progressive structural doming in the central part of the Mozambique Channel (Ponte, 2018). Oligocene strata were eroded and the Angoche2

857 incision was probably totally erased by the Z1 erosional phase in response to the long-lasting 858 elevation of the seafloor during Late Miocene. This incision period must have produced an 859 important volume of material (estimated to $560 \mathrm{~km}^{3}$, see section 5.2 ) that is probably deposited downstream in the Depositional Area. It was however not possible to individualize the seismic units associated to this episode of strong erosion.

862 Later on in the Late Miocene a new aggradational stage happened were the Z1 incision was 863 infilled with onlapping sediments probably in order to establish a new equilibrium profile and 864 deposition started in the Intermediate Basin. 
The Plio-Pleistocene is characterized by a combination of aggradational and erosional events that resulted in a diversification of deposits. Fine-grained turbidites are observed at the left overbank of the Zambezi Fan, while mainly coarse-grained turbidites are present in the Intermediate Basin and Depositional Area. Contourites occur on the right bank of the Zambezi Valley as well as in the Angoche basin. Additionally, this period is characterized by synchronicity of different terrigenous input sources (Zambezi and Madagascar margin). The Zambezi Valley (incision Z2; Figs. 18, 19) is in a rather equilibrium state. It was lately infilled by a MTD, observed $800 \mathrm{~km}$ along the Zambezi Valley more downstream than the Tsiribihina confluence (Fig. 18, 19 profiles 1-11). Considering the maximum thickness of this MTD $(0.2$ stwt, $200 \mathrm{~m}$ ), the mean wideness of the $\mathrm{Z2}$ incision $(4 \mathrm{~km})$, and a rectangular prism as an approximation of the shape of the MTD, a rough estimation of the volume of transported sediments can be calculated to $640 \mathrm{~km}^{3}$. Together with the MTDs in the distal Depositional Area, the occurrence of these mass transport deposits attests to the recurrence of instabilities in the Plio-Pleistocene period, also shown on the Mozambique slope by Ponte (2018).

The Zambezi Fan has been shown to be dominantly erosional during very recent times (Fierens et al., 2019; Miramontes et al., 2019). The erosional regime is attested by multiple generations of incisions in the thalweg (corresponding to the Z3 incision), erosion of the valley flanks possibly by bottom currents, and absence (or rarity) of fine-grained deposits (pirating of the turbulent suspension cloud by contouritic currents?). Contrarily, in the Ponded Fan, the depositional regime is mainly aggradational.

\section{CONCLUSION}

Academic high-resolution seismic data complemented with industrial data allowed deciphering the Oligocene to present architectural evolution of the Zambezi turbidite system including the Zambezi channelized Fan and the Intermediate Ponded Fan. Seismic interpretation allowed distinguishing five major depositional units and four principal incisional 
episodes. The respective depositional timing of these units is established based on the

893 regional stratigraphy from Ponte (2018).

894 The main results can be summarized as follows:

895 - The Zambezi turbidite system is shown to be composed of both turbidites and

896 contourites that were deposited mostly synchronously along the Mozambique and

897 Madagascar margins. The history of the turbidite system shows an alternation of

$898 \quad$ aggradational and erosional processes.

- Stratigraphic correlations place the Serpa Pinto (and Angoche1) deposition (unit U1)

900 during the Oligocene, the distal turbiditic deposition (unit U2) during Early Miocene, the Angoche2 and Zambezi1 incisions during Middle - Late Miocene and the Zambezi2 incision at the beginning of the Pliocene. Units U3 and U4 were deposited during the Plio-Quaternary.

- Succession of valleys that fed the sedimentary units evidences an anticlockwise shift of feeding axes from the Serpa Pinto Valley to the Angoche Valley and finally towards the Zambezi Valley. This goes together with a shift of the drainage basins that fed the fan, from the northern most watersheds of the Mozambique (Lurio and possible other northern rivers) to the Angoche watershed (more south), then to the Zambezi watershed (central Mozambique).

- The main incision event occurred during the Late Miocene, when the valley suffered the effects of a structural doming in the central part of the Mozambique Channel. The continuous elevation of the seafloor forced the profound entrenchment of the Zambezi1 incision ( 400 m of erosion), which supposedly is cause of the observed absence of lateral levees proximal to the Zambezi Valley. Products of this strong erosional regime (estimated to $560 \mathrm{~km}^{3}$ of reworked sediments) are supposed to be transported to the distal Depositional Area.

- Most turbiditic deposits in the studied area are either fine-grained levee turbidites (units U1 and U4) or coarse-grained channel-mouth turbidites (U2, U5 and Depositional Area). 
- Mass-movement processes, recurrent on the Mozambique slope (Ponte, 2018) since the Pliocene have been observed mainly in the Zambezi Valley, in the distal depositional area, and on the Madagascar margin.

- Contouritic sedimentation is at least continuous since the Oligocene. The drift sediments are supposed to be supplied by turbiditic processes (current overflow) and both (i.e. turbiditic and contouritic) depositional processes occur most often synchronous (i.e. U3 during U4 levee deposition, possibly during northern Serpa Pinto deposition and close to the Davie Ridge). Besides the two thickest Oligocene and Miocene drifts upstream on the margin, a prominent Plio-Quaternary N-S contourite drift (U3) is identified on the right flank of the Zambezi Valley where bottom current controlled bedforms are observed.

This study has important implications for the current understanding of deep-marine turbidite systems. It demonstrates the sensitivity of large depositional systems to changing basin floor topography created by progressive structural deformation in terms of the architectural elements and the associated capacity to transfer sediments downstream.

\section{ACKNOWLEDGEMENTS}

The PhD thesis of Ruth Fierens was co-funded by TOTAL and IFREMER as part of the PAMELA (Passive Margin Exploration Laboratories) scientific project. The PAMELA project is a scientific project led by Ifremer and TOTAL in collaboration with Université de Bretagne Occidentale, Université Rennes 1, Université Pierre and Marie Curie, CNRS and IFP-EN. We thank the Captains and crew members of the 2014 and 2015 cruises PTOLEMEE and PAMELA-MOZ2 onboard the R/V L'Atalante and PAMELA-MOZ4 onboard of R/V Pourquoi pas? as well as the technicians from Genavir that ensured acquisitions of the geophysical data. The onboard scientific teams of PAMELA surveys are greatly thanked for their contribution to data acquisitions. Seismic data were analyzed using Kingdom Suite software, kindly made available to UBO by IHS in the framework of their Educational Grant Program. The authors are also grateful to Jacob A. Covault and David Hodgson for their critical reading and constructive 
discussions at a preliminary stage of this work. We greatly acknowledge the reviews from the

Editor in Chief Istvan Csato and from an anonymous reviewer who greatly helped improving the paper.

\section{REFERENCES}

Adeogba, A.A., McHargue, T.R., Graham, S.A., 2005. Transient fan architecture and depositional controls from near-surface 3-D seismic data, Niger Delta continental slope. AAPG bulletin 89, 627-643. https://doi.org/10.1306/11200404025

Alexander, J., Morris, S., 1994. Observations on experimental, nonchannelized, highconcentration turbidity currents and variations in deposits around obstacles. Journal of Sedimentary Research 64, 899-909. https://doi.org/10.1306/D4267F00-2B26-11D7$8648000102 \mathrm{C} 1865 \mathrm{D}$

Amante, C., Eakins, B.W., 2009. ETOPO1 arc-minute global relief model: procedures, data sources and analysis. NOAA Technical Memorandum NESDIS NGDC-24, Accessed 25 Feb. 2019. https://doi.org/10.7289/V5C8276M

Babonneau, N., Savoye, B., Cremer, M., Klein, B., 2002. Morphology and architecture of the present canyon and channel system of the Zaire deep-sea fan. Marine and Petroleum Geology 19, 445-467. https://doi.org/10.1016/S0264-8172(02)00009-0

Baby, G., 2017. Mouvements verticaux des marges passives d'Afrique australe depuis 130 Ma, étude couplée: stratigraphie de bassin: analyse des formes du relief. Ph.D. Thesis, Université de Rennes 1. France. p. 363.

Badhani, S., Cattaneo, A., Dennielou, B., Leroux, E., Colin, F., Thomas, Y., Jouet, G., Rabineau, M., Droz, L., 2020. Morphology of retrogressive failures in the Eastern Rhone interfluve during the last glacial maximum (Gulf of Lions, Western Mediterranean). Geomorphology 351, 106894. https://doi.org/10.1016/j.geomorph.2019.106894

Beaubouef, R.T., Friedmann, S.J., 2000. High Resolution Seismic/Sequence Stratigraphic Framework for the Evolution of Pleistocene Intra Slope Basins, Western Gulf of Mexico: 
Depositional Models and Reservoir Analogs. Presented at the Deep-water reservoirs of the world: Gulf Coast Section SEPM 20th Annual Research Conference.

975

976

977

978

979

980

981

982

983

984

985

986

987

988

989

990

991

992

993

994

995

996

997

998

999

1000

Beiersdorf, H., Kudrass, H.-R., Stackelberg, U. von, 1980. Placer Deposits of limenite and Zircon on the Zambezi Shelf. Geologisches Jahrbuch Reihe D 500, 36, 1-85.

Bourillet, J.-F., Ferry, J.-N., Bourges, P., 2013. PAMELA "PASSIVE MARGINS EXPLORATION LABORATORIES." http://dx.doi.org/10.18142/236

Bozzano, G., Cerredo, M.E., Remesal, M., Steinmann, L., Hanebuth, T.J.J., Schwenk, T., Baqués, M., Hebbeln, D., Spoltore, D., Silvestri, O., Acevedo, R.D., Spiess, V., Violante, R.A., Kasten, S., 2021. Dropstones in the Mar del Plata Canyon Area (SW Atlantic): Evidence for Provenance, Transport, Distribution, and Oceanographic Implications. Geochem Geophys Geosyst 22. https://doi.org/10.1029/2020GC009333

Breitzke, M., Wiles, E., Krocker, R., Watkeys, M.K., Jokat, W., 2017. Seafloor morphology in the Mozambique Channel: evidence for long-term persistent bottom-current flow and deep-reaching eddy activity. Marine Geophysical Research 38, 241-269. https://doi.org/10.1007/s11001-017-9322-7

Bursik, M.I., Woods, A.W., 2000. The Effects of Topography on Sedimentation from ParticleLaden Turbulent Density Currents. Journal of Sedimentary Research 70, 53-63. https://doi.org/10.1306/2DC408FE-0E47-11D7-8643000102C1865D

Calais, E., Ebinger, C., Hartnady, C., Nocquet, J.M., 2006. Kinematics of the East African Rift from GPS and earthquake slip vector data. Geological Society, London, Special Publications 259, 9-22. https://doi.org/10.1144/GSL.SP.2006.259.01.03

Castelino, J.A., Reichert, C., Jokat, W., 2017. Mesozoic and Early Cenozoic sediment influx and morphology of the Mozambique Basin. Marine Geophysical Research. https://doi.org/10.1007/s11001-017-9305-8

Clark, I.R., Cartwright, J.A., 2009. Interactions between submarine channel systems and deformation in deepwater fold belts: Examples from the Levant Basin, Eastern Mediterranean sea. Marine and Petroleum Geology 26, 1465-1482. https://doi.org/10.1016/j.marpetgeo.2009.05.004 
1001

1002

1003

1004

1005

1006

1007

1008

1009

1010

1011

1012

1013

1014

1015

1016

1017

1018

1019

1020

1021

1022

1023

1024

1025

1026

Cochran, J.R., 1988. Somali Basin, Chain Ridge, and origin of the Northern Somali Basin gravity and geoid low. Journal of Geophysical Research: Solid Earth 93, 11985-12008. https://doi.org/10.1029/JB093iB10p11985

Coffin, M.F., Rabinowitz, P.D., 1987. Reconstruction of Madagascar and Africa: evidence from the Davie fracture zone and western Somali basin. Journal of Geophysical Research: Solid Earth 92, 9385-9406. https://doi.org/10.1029/JB092iB09p09385

Counts, J.W., Jorry, S.J., Leroux, E., Miramontes, E., Jouet, G., 2018. Sedimentation adjacent to atolls and volcano-cored carbonate platforms in the Mozambique Channel (SW Indian Ocean). Marine Geology 404, 41-59.

https://doi.org/10.1016/j.margeo.2018.07.003

Courgeon, S., Bachèlery, P., Jouet, G., Jorry, S.J., Bou, E., BouDagher-Fadel, M.K., Révillon, S., Camoin, G., Poli, E., 2018. The offshore east African rift system: new insights from the Sakalaves seamounts (Davie Ridge, SW Indian Ocean). Terra Nova 30(5), 380-388.

Courgeon, S., Jorry, S.J., Camoin, G.F., BouDagher-Fadel, M., Jouet, G., Révillon, S., Bachèlery, P., Pelleter, E., Borgomano, J., Poli, E., 2016. Growth and demise of Cenozoic isolated carbonate platforms: New insights from the Mozambique Channel seamounts (SW Indian Ocean). Marine Geology 380, 90-105. https://doi.org/10.1016/j.margeo.2016.07.006

Courgeon, S., Jorry, S.J., Jouet, G., Camoin, G., BouDagher-Fadel, M., Bachèlery, P., Caline, B., Boichard, R., Révillon, S., Thomas, Y., 2017. Impact of tectonic and volcanism on the Neogene evolution of isolated carbonate platforms (SW Indian Ocean). Sedimentary Geology 355, 114-131. https://doi.org/10.1016/j.sedgeo.2017.04.008

Dawson, J.B., 1992. Neogene tectonics and volcanicity in the North Tanzania sector of the Gregory Rift Valley: contrasts with the Kenya sector. Tectonophysics 204, 81-92. https://doi.org/10.1016/0040-1951(92)90271-7 
Delaunay, A., 2018. Les mouvements verticaux de Madagascar (90-0 Ma): une analyse couplée des formes du relief et de l'enregistrement sédimentaire des marges ouest malgaches. Ph.D. Thesis, Université de Rennes 1. France. p. 374.

Dennielou, B., Jégou, I., Droz, L., Jouet, G., Cattaneo, A., Berné, S., Aslanian, D., Loubrieu, B., Rabineau, M., Bermell, S., 2019. Major modification of sediment routing by a large Mass Transport Deposit in the Gulf of Lions (Western Mediterranean). Marine Geology 411, 1-20. https://doi.org/10.1016/j.margeo.2019.01.011

Deptuck, M.E., Steffens, G.S., Barton, M., Pirmez, C., 2003. Architecture and evolution of upper fan channel-belts on the Niger Delta slope and in the Arabian Sea. Marine and Petroleum Geology 20, 649-676. https://doi.org/10.1016/j.marpetgeo.2003.01.004

Deville, E., Marsset, T., Courgeon, S., Jatiault, R., Ponte, J.-P., Thereau, E., Jouet, G., Jorry, S.J., Droz, L., 2018. Active fault system across the oceanic lithosphere of the Mozambique Channel: Implications for the Nubia-Somalia southern plate boundary. Earth and Planetary Science Letters 502, 210-220. https://doi.org/10.1016/j.epsl.2018.08.052

Droz, L., Mougenot, D., 1987. Mozambique upper fan: origin of depositional units. AAPG Bulletin 71, 1355-1365.

Fierens, R., Droz, L., Toucanne, S., Raisson, F., Jouet, G., Babonneau, N., Miramontes, E., Landurain, S., Jorry, S.J., 2019. Late Quaternary geomorphology and sedimentary processes in the Zambezi turbidite system (Mozambique Channel). Geomorphology 334, 1-28. https://doi.org/10.1016/j.geomorph.2019.02.033

Fierens, R., Toucanne, S., Droz, L., Jouet, G., Raisson, F., Jorissen, E.L., Bayon, G., Giraudeau, J., Jorry, S.J., 2020. Quaternary sediment dispersal in the Zambezi turbidite system (SW Indian Ocean). Marine Geology 428, 106276. https://doi.org/10.1016/j.margeo.2020.106276

Franke, D., Jokat, W., Ladage, S., Stollhofen, H., Klimke, J., Lutz, R., Mahanjane, E.S., Ehrhardt, A., Schreckenberger, B., 2015. The offshore East African Rift System: 
Structural framework at the toe of a juvenile rift. Tectonics 34, 2086-2104. https://doi.org/10.1002/2015TC003922

Gaina, C., Van Hinsbergen, D.J., Spakman, W., 2015. Tectonic interactions between India and Arabia since the Jurassic reconstructed from marine geophysics, ophiolite geology, and seismic tomography. Tectonics 34, 875-906. https://doi.org/10.1002/2014TC003780

García, M., Hernández-Molina, F.J., Llave, E., Stow, D.A.V., León, R., Fernández-Puga, M.C., Diaz del Río, V., Somoza, L., 2009. Contourite erosive features caused by the Mediterranean Outflow Water in the Gulf of Cadiz: Quaternary tectonic and oceanographic implications. Marine Geology 257, 24-40. https://doi.org/10.1016/j.margeo.2008.10.009

Garzanti, E., Pastore, G., Resentini, A., Vezzoli, G., Vermeesch, P., Ngube, L., Niekerk, E.V., Jouet, G., Dall'Asta, M., in press. The Segmented Zambezi Sedimentary System from Source to Sink 1. Sand Petrology and Heavy Minerals. The Journal of Geology. https://doi.org/10.1086/715792

Garziglia, S., Migeon, S., Ducassou, E., Loncke, L., Mascle, J., 2008. Mass-transport deposits on the Rosetta province (NW Nile deep-sea turbidite system, Egyptian margin): Characteristics, distribution, and potential causal processes. Marine Geology 250, 180198. https://doi.org/10.1016/j.margeo.2008.01.016

GEBCO, 2014. GEBCO_2014 Grid. British Oceanographic Data Centre (BODC). Available at: http://www.gebco.net/data_and_products/gridded_bathymetry_data/.

Gee, M., Masson, D.G., Watts, A., 2001. Passage of debris flows and turbidity currents through a topographic constriction: seafloor erosion and deflection of flow pathways.

Gee, M.J.R., Gawthorpe, R.L., 2006. Submarine channels controlled by salt tectonics: Examples from 3D seismic data offshore Angola. Marine and Petroleum Geology 23, 443-458. https://doi.org/10.1016/j.marpetgeo.2006.01.002

Hall, I.R., Hemming, S.R., LeVay, L.J., Barker, S.R., Berke, M.A., Brentegani, L., Caley, T., Cartagena-Sierra, A., Charles, C.D., Coenen, J.J., 2016. International Ocean Discovery 
Program; Expedition 361 preliminary report; South African climates (Agulhas LGM density profile); 30 January-31 March 2016. https://doi.org/10.14379/iodp.pr.361.2016

Haughton, P.D.W., 2000. Evolving turbidite systems on a deforming basin floor, Tabernas, SE Spain. Sedimentology 47, 497-518. https://doi.org/10.1046/j.1365-3091.2000.00293.x

Hernández-Molina, F.J., Paterlini, M., Somoza, L., Violante, R., Arecco, M.A., de Isasi, M., Rebesco, M., Uenzelmann-Neben, G., Neben, S., Marshall, P., 2010. Giant mounded drifts in the Argentine Continental Margin: Origins, and global implications for the history of thermohaline circulation. Marine and Petroleum Geology 27, 1508-1530. https://doi.org/10.1016/j.marpetgeo.2010.04.003

Hodgson, D.M., Haughton, P.D.W., 2004. Impact of syndepositional faulting on gravity current behaviour and deep-water stratigraphy: Tabernas-Sorbas Basin, SE Spain. Geological Society, London, Special Publications 222, 135-158. https://doi.org/10.1144/GSL.SP.2004.222.01.08

Howlett, D.M., Gawthorpe, R.L., Ge, Z., Rotevatn, A., Jackson, C.A.-L., 2020. Turbidites, topography and tectonics: Evolution of submarine channel-lobe systems in the saltinfluenced Kwanza Basin, offshore Angola. Basin Research n/a. https://doi.org/10.1111/bre.12506

Hsiung, K.-H., Yu, H.-S., Chiang, C.-S., 2018. The modern Kaoping transient fan offshore SW Taiwan: Morphotectonics and development. Geomorphology 300, 151-163. https://doi.org/10.1016/j.geomorph.2017.10.013

Huyghe, P., Foata, M., Deville, E., Mascle, G., Group, C.W., 2004. Channel profiles through the active thrust front of the southern Barbados prism. Geology 32, 429-432. https://doi.org/10.1130/G20000.1

Imbo, Y., De Batist, M., Canals, M., Prieto, M.J., Baraza, J., 2003. The Gebra Slide: a submarine slide on the Trinity Peninsula Margin, Antarctica. Marine Geology 193, 235252. https://doi.org/10.1016/S0025-3227(02)00664-3

Janocko, M., Nemec, W., Henriksen, S., Warchoł, M., 2013. The diversity of deep-water sinuous channel belts and slope valley-fill complexes. Marine and Petroleum Geology, 
Special Issue: Internal architecture, bedforms and geometry of turbidite channels 41, 7-

Jorry, S.J., 2014. PTOLEMEE cruise, RV L'Atalante. http://dx.doi.org/10.17600/14000900 Jorry, S.J., Camoin, G.F., Jouet, G., Le Roy, P., Vella, C., Courgeon, S., Prat, S., Fontanier, C., Paumard, V., Boulle, J., 2016. Modern sediments and Pleistocene reefs from isolated carbonate platforms (Iles Eparses, SW Indian Ocean): A preliminary study. Acta Oecologica 72, 129-143. https://doi.org/10.1016/j.actao.2015.10.014 Jouet, G., Deville, E., 2015. PAMELA-MOZ04 cruise, RV Pourquoi Pas? http://dx.doi.org/10.17600/15000700

Kolla, V., Eittreim, S., Sullivan, L., Kostecki, J.A., Burckle, L.H., 1980a. Current-controlled, abyssal microtopography and sedimentation in Mozambique Basin, southwest Indian Ocean. Marine Geology 34, 171-206. https://doi.org/10.1016/0025-3227(80)90071-7

Kolla, V., Kostecki, J.A., Henderson, L., Hess, L., 1980b. Morphology and Quaternary sedimentation of the Mozambique Fan and environs, southwestern Indian Oceans. Sedimentology 27, 357-378. https://doi.org/10.1111/j.1365-3091.1980.tb01188.x

Kukowski, N., Schillhorn, T., Huhn, K., von Rad, U., Husen, S., Flueh, E.R., 2001. Morphotectonics and mechanics of the central Makran accretionary wedge off Pakistan. Marine Geology 173, 1-19. https://doi.org/10.1016/S0025-3227(00)00167-5

Le Gall, B., Nonnotte, P., Rolet, J., Benoit, M., Guillou, H., Mousseau-Nonnotte, M., Albaric, J., Deverchère, J., 2008. Rift propagation at craton margin.: Distribution of faulting and volcanism in the North Tanzanian Divergence (East Africa) during Neogene times. Tectonophysics 448, 1-19. https://doi.org/10.1016/j.tecto.2007.11.005

Leinweber, V.T., Jokat, W., 2012. The Jurassic history of the Africa-Antarctica corridor-new constraints from magnetic data on the conjugate continental margins. Tectonophysics 530, 87-101. https://doi.org/10.1016/j.tecto.2011.11.008

Loncke, L., Gaullier, V., Droz, L., Ducassou, E., Migeon, S., Mascle, J., 2009. Multi-scale slope instabilities along the Nile deep-sea fan, Egyptian margin: a general overview. 

Marine and Petroleum Geology 26, 633-646. https://doi.org/10.1016/j.marpetgeo.2008.03.010

Lort, J.M., Limond, W.Q., Segoufin, J., Patriat, P., Delteil, J.R., Damotte, B., 1979. New seismic data in the Mozambique Channel. Marine Geophysical Research 4, 71-89.

Mahanjane, E.S., 2014. The Davie Fracture Zone and adjacent basins in the offshore Mozambique Margin - A new insights for the hydrocarbon potential. Marine and Petroleum Geology 57, 561-571. https://doi.org/10.1016/j.marpetgeo.2014.06.015

Mahanjane, E.S., 2012. A geotectonic history of the northern Mozambique Basin including the Beira High - A contribution for the understanding of its development. Marine and Petroleum Geology 36, 1-12. https://doi.org/10.1016/j.marpetgeo.2012.05.007

Maselli, V., Kroon, D., lacopini, D., Wade, B.S., Pearson, P.N., Haas, H. de, 2020. Impact of the East African Rift System on the routing of the deep-water drainage network offshore Tanzania, western Indian Ocean. Basin Research 32, 789-803. https://doi.org/10.1111/bre.12398

Mayall, M., Lonergan, L., Bowman, A., James, S., Mills, K., Primmer, T., Pope, D., Rogers, L., Skeene, R., 2010. The response of turbidite slope channels to growth-induced seabed topography. Bulletin 94, 1011-1030. https://doi.org/10.1306/01051009117

Milliman, J.D., Farnsworth, K.L., 2011. River discharge to the coastal ocean: a global synthesis. Cambridge University Press, p. 392.

Milliman, J.D., Syvitski, J.P., 1992. Geomorphic/tectonic control of sediment discharge to the ocean: the importance of small mountainous rivers. The Journal of Geology 100, 525544. https://doi.org/10.1086/629606

Miramontes, E., 2016. Submarine landslides in the Northern Tyrrhenian Sea and relationship with the turbiditic and contouritic deposits: morphology, stratigraphy, geotechnics and modelling. Ph.D. Thesis, Université de Bretagne occidentale, France. p. 215.

Miramontes, E., Penven, P., Fierens, R., Droz, L., Toucanne, S., Jorry, S.J., Jouet, G., Pastor, L., Jacinto, R.S., Gaillot, A., 2019. The influence of bottom currents on the Zambezi Valley morphology (Mozambique Channel, SW Indian Ocean): In situ current 
observations and hydrodynamic modelling. Marine Geology 410, 42-55. https://doi.org/10.1016/j.margeo.2019.01.002

Miramontes, E., Thiéblemont, A., Babonneau, N., Penven, P., Raisson, F., Droz, L., Jorry, S.J., Fierens, R., Counts, J.W., Wilckens, H., Cattaneo, A., Jouet, G., 2021. Contourite and mixed turbidite-contourite systems in the Mozambique Channel (SW Indian Ocean): Link between geometry, sediment characteristics and modelled bottom currents. Marine Geology 437, 106502. https://doi.org/10.1016/j.margeo.2021.106502

Mitchum, R.M., Vail, P.R., Sangree, J.B., 1977. Seismic stratigraphy and global changes of sea level: Part 6. Stratigraphic interpretation of seismic reflection patterns in depositional sequences: Section 2. Application of seismic reflection configuration to stratigraphic interpretation. in 'Seismic Stratigraphy-Applications to Hydrocarbon Exploration (C. E. Payton, Ed.)'. 53-62.

Morgan, R., 2004. Structural Controls on the Positioning of Submarine Channels on the Lower Slopes of the Niger Delta. Geological Society, London, Memoirs 29, 45-52. https://doi.org/10.1144/GSL.MEM.2004.029.01.05

Morris, S.A., Alexander, J., 2003. Changes in Flow Direction at a Point Caused by Obstacles During Passage of a Density Current. Journal of Sedimentary Research 73, 621-629. https://doi.org/10.1306/112502730621

Mougenot, D., Recq, M., Virlogeux, P., Lepvrier, C., 1986. Seaward extension of the East African Rift. Nature 321, 599-603. https://doi.org/10.1038/321599a0

Mueller, C.O., Jokat, W., Schreckenberger, B., 2016. The crustal structure of Beira High, central Mozambique-Combined investigation of wide-angle seismic and potential field data. Tectonophysics 683, 233-254. https://doi.org/10.1016/j.tecto.2016.06.028

Mutti, E., Normark, W.R., 1991. An Integrated Approach to the Study of Turbidite Systems, in: Weimer, P., Link, M.H. (Eds.), Seismic Facies and Sedimentary Processes of Submarine Fans and Turbidite Systems, Frontiers in Sedimentary Geology. Springer New York, New York, NY, pp. 75-106. https://doi.org/10.1007/978-1-4684-8276-8_4 
Mutti, E., Normark, W.R., 1987. Comparing examples of modern and ancient turbidite systems: problems and concepts, in: Marine Clastic Sedimentology. Springer, pp. 1-38.

Nugent, C., 1990. The Zambezi River: tectonism, climatic change and drainage evolution. Palaeogeography, Palaeoclimatology, Palaeoecology 78, 55-69. https://doi.org/10.1016/0031-0182(90)90204-K

Oluboyo, A.P., Gawthorpe, R.L., Bakke, K., Hadler-Jacobsen, F., 2014. Salt tectonic controls on deep-water turbidite depositional systems: Miocene, southwestern Lower Congo Basin, offshore Angola. Basin Research 26, 597-620. https://doi.org/10.1111/bre.12051

Piper, Hiscott, Normark, 1999. Outcrop-scale acoustic facies analysis and latest Quaternary development of Hueneme and Dume submarine fans, offshore California. Sedimentology 46, 47-78. https://doi.org/10.1046/j.1365-3091.1999.00203.x

Ponte, J.-P., 2018. La marge africaine du canal du Mozambique (le système turbiditique du Zambèze) : une approche « Source to Sink» au Méso - Cénozoïque. Ph.D. Thesis, Université de Rennes 1. France. p. 351.

Ponte, J.-P., Robin, C., Guillocheau, F., Popescu, S., Suc, J.-P., Dall'Asta, M., MelinteDobrinescu, M.C., Bubik, M., Dupont, G., Gaillot, J., 2019. The Zambezi delta (Mozambique channel, East Africa): High resolution dating combining bio- orbital and seismic stratigraphies to determine climate (palaeoprecipitation) and tectonic controls on a passive margin. Marine and Petroleum Geology 105, 293-312. https://doi.org/10.1016/j.marpetgeo.2018.07.017

Rabinowitz, P.D., Coffin, M.F., Falvey, D., 1983. The Separation of Madagascar and Africa. Science 220, 67-69. https://doi.org/10.1126/science.220.4592.67

Raisson, F., Cazzola, C., Ferry, J.-N., 2016. Deep oceanic currents and sea floor interactions offshore SE Africa. Presented at the EGU General Assembly Conference Abstracts, 18, Vienna (Austria), p. 18459.

Reading, H.G., 1991. The classification of deep-sea depositional systems by sediment caliber and feeder system. Journal of the Geological Society 148, 427-430. https://doi.org/10.1144/gsjgs.148.3.0427 
Reading, H.G., Richards, M., 1994. Turbidite systems in deep-water basin margins classified by grain size and feeder system. AAPG bulletin 78, 792-822.

Reeves, C., 2014. The position of Madagascar within Gondwana and its movements during Gondwana dispersal. Journal of African Earth Sciences, Geology and metallogeny of the Precambrian basement of Madagascar 94, 45-57. https://doi.org/10.1016/j.jafrearsci.2013.07.011

Reichert, C., Aslanian, D., 2007. MD 163 / MOBAMASIS cruise,Marion Dufresne R/V. https://doi.org/10.17600/7200110

Robin, C., Droz, L., 2014. PAMELA-MOZ02 cruise, RV L'Atalante. http://dx.doi.org/10.17600/14001100

Roquette, E., 2016. La marge transformante nord-Mozambicaine : bilan érosion sédimentation. (Technical report). Université de Rennes 1.

Rowan, M.G., Weimer, P., 1998. Salt-Sediment Interaction, Northern Green Canyon and Ewing Bank (Offshore Louisiana), Northern Gulf of Mexico. AAPG Bulletin 82, 10551082.

Saller, A.H., Noah, J.T., Ruzuar, A.P., Schneider, R., 2004. Linked lowstand delta to basinfloor fan deposition, offshore Indonesia: An analog for deep-water reservoir systems. AAPG Bulletin 88, 21-46. https://doi.org/10.1306/09030303003

Salman, G., Abdula, I., 1995. Development of the Mozambique and Ruvuma sedimentary basins, offshore Mozambique. Sedimentary Geology 96, 7-41. https://doi.org/10.1016/0037-0738(95)00125-R

Saria, E., Calais, E., Stamps, D.S., Delvaux, D., Hartnady, C.J.H., 2014. Present-day kinematics of the East African Rift. Journal of Geophysical Research: Solid Earth 119, 3584-3600. https://doi.org/10.1002/2013JB010901

Schulz, H., Lückge, A., Emeis, K.-C., Mackensen, A., 2011. Variability of Holocene to Late Pleistocene Zambezi riverine sedimentation at the upper continental slope off Mozambique, $15^{\circ}-21^{\circ} \mathrm{S}$. Marine Geology 286, 21-34. https://doi.org/10.1016/j.margeo.2011.05.003 
Segoufin, J., Patriat, P., 1981. Reconstructions de l'Ocean Indien Occidental pour les epoques des anomalies M21, M2 et 34; Paleoposition de Madagascar. Bulletin de la Société géologique de France 7, 603-607. https://doi.org/10.2113/gssgfbull.S7XXIII.6.603

Simpson, E.S.W., 1974. Sites 243 and 244. Vol. 25, 177-186. https://doi.org/10.2973/dsdp.proc.25.106.1974

Sinclair, H.D., Tomasso, M., 2002. Depositional evolution of confined turbidite basins. Journal of Sedimentary Research 72, 451-456.

Smith, R., 2004. Silled sub-basins to connected tortuous corridors: sediment distribution systems on topographically complex sub-aqueous slopes. Geological Society, London, Special Publications 222, 23-43. https://doi.org/10.1144/GSL.SP.2004.222.01.03

Stamps, D.S., laffaldano, G., Calais, E., 2015. Role of mantle flow in Nubia-Somalia plate divergence. Geophysical Research Letters 42, 290-296. https://doi.org/10.1002/2014GL062515

Stow, D.A.V., Howell, D.G., Nelson, C.H., 1985. Sedimentary, Tectonic, and Sea-Level Controls, in: Bouma, A.H., Normark, W.R., Barnes, N.E. (Eds.), Submarine Fans and Related Turbidite Systems, Frontiers in Sedimentary Geology. Springer, New York, NY, pp. 15-22. https://doi.org/10.1007/978-1-4612-5114-9_4

Thiéblemont, A., Hernández-Molina, F.J., Ponte, J.-P., Robin, C., Guillocheau, F., Cazzola, C., Raisson, F., 2020. Seismic stratigraphic framework and depositional history for Cretaceous and Cenozoic contourite depositional systems of the Mozambique Channel, SW Indian Ocean. Marine Geology 106192. https://doi.org/10.1016/j.margeo.2020.106192

Thomas, D.S., Shaw, P.A., 1988. Late Cainozoic drainage evolution in the Zambezi Basin: geomorphological evidence from the Kalahari rim. Journal of African Earth Sciences (and the Middle East) 7, 611-618. https://doi.org/10.1016/0899-5362(88)90111-X 
Thompson, J.O., 2017. The opening of the Indian Ocean: what is the impact on the East African, Madagascar and Antartictic margins, and what are the origins if the aseismic ridges? Ph.D. Thesis, Université de Rennes 1, France. p. 189.

Thompson, J.O., Moulin, M., Aslanian, D., de Clarens, P., Guillocheau, F., 2019. New starting point for the Indian Ocean: Second phase of breakup for Gondwana. EarthScience Reviews 191, 26-56. https://doi.org/10.1016/j.earscirev.2019.01.018

van Aken, H.M., Ridderinkhof, H., de Ruijter, W.P., 2004. North Atlantic deep water in the south-western Indian Ocean. Deep Sea Research Part I: Oceanographic Research Papers 51, 755-776. https://doi.org/10.1016/j.dsr.2004.01.008

Van Rooij, D., Iglesias, J., Hernández-Molina, F.J., Ercilla, G., Gomez-Ballesteros, M., Casas, D., Llave, E., De Hauwere, A., Garcia-Gil, S., Acosta, J., Henriet, J.-P., 2010. The Le Danois Contourite Depositional System: Interactions between the Mediterranean Outflow Water and the upper Cantabrian slope (North Iberian margin). Marine Geology 274, 1-20. https://doi.org/10.1016/j.margeo.2010.03.001

Walford, H., White, N., Sydow, J., 2005. Solid sediment load history of the Zambezi Delta. Earth and Planetary Science Letters 238, 49-63. https://doi.org/10.1016/j.epsl.2005.07.014

Wiles, E., Green, A., Watkeys, M., Jokat, W., 2017a. The Zambezi Channel: A new perspective on submarine channel evolution at low latitudes. Geomorphology 286, 121132. https://doi.org/10.1016/j.geomorph.2017.02.014

Wiles, E., Green, A.N., Watkeys, M.K., Jokat, W., 2017b. Zambezi continental margin: compartmentalized sediment transfer routes to the abyssal Mozambique Channel. Marine Geophysical Research 1-14. https://doi.org/10.1007/s11001-016-9301-4

Wiles, E., Watkeys, M., Jokat, W., 2020. Surface expression of microplate boundary kinematics: An isolated abyssal hill in the Mozambique Channel. Journal of African Earth Sciences 168, 103830. https://doi.org/10.1016/j.jafrearsci.2020.103830 
1299 Winker, C.D., 1996. High-resolution seismic stratigraphy of a late Pleistocene submarine fan ponded by salt-withdrawal mini-basins on the Gulf of Mexico continental slope. Presented at the Offshore Technology Conference, Offshore Technology Conference, pp. 619-628.

1302 Zindorf, M., Rooze, J., Meile, C., März, C., Jouet, G., Newton, R., Brandily, C., Pastor, L., 2021. The evolution of early diagenetic processes at the Mozambique margin during the last glacial-interglacial transition. Geochimica et Cosmochimica Acta 300, 79-94. https://doi.org/10.1016/j.gca.2021.02.024 


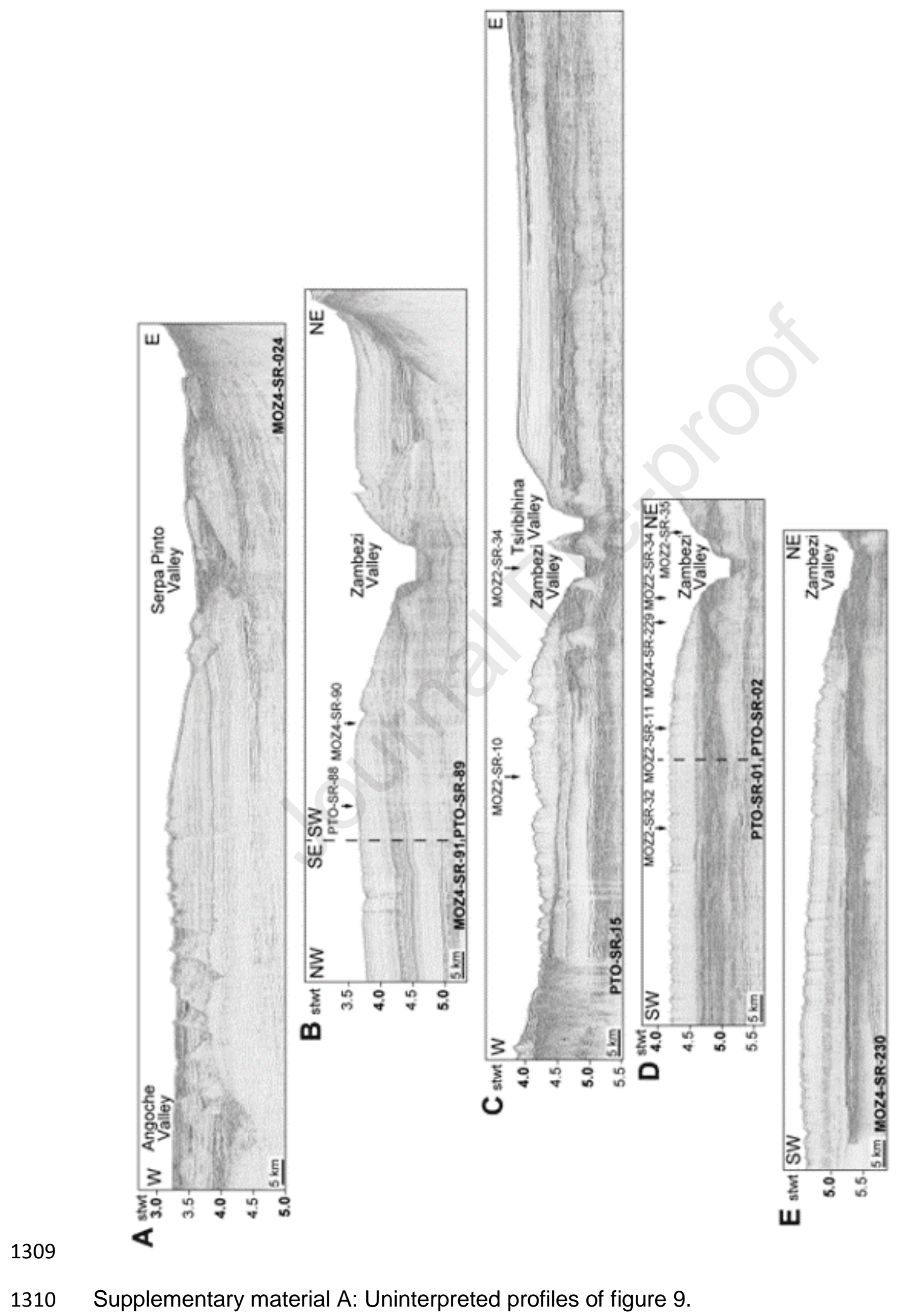




\section{Supplementary material B-1}
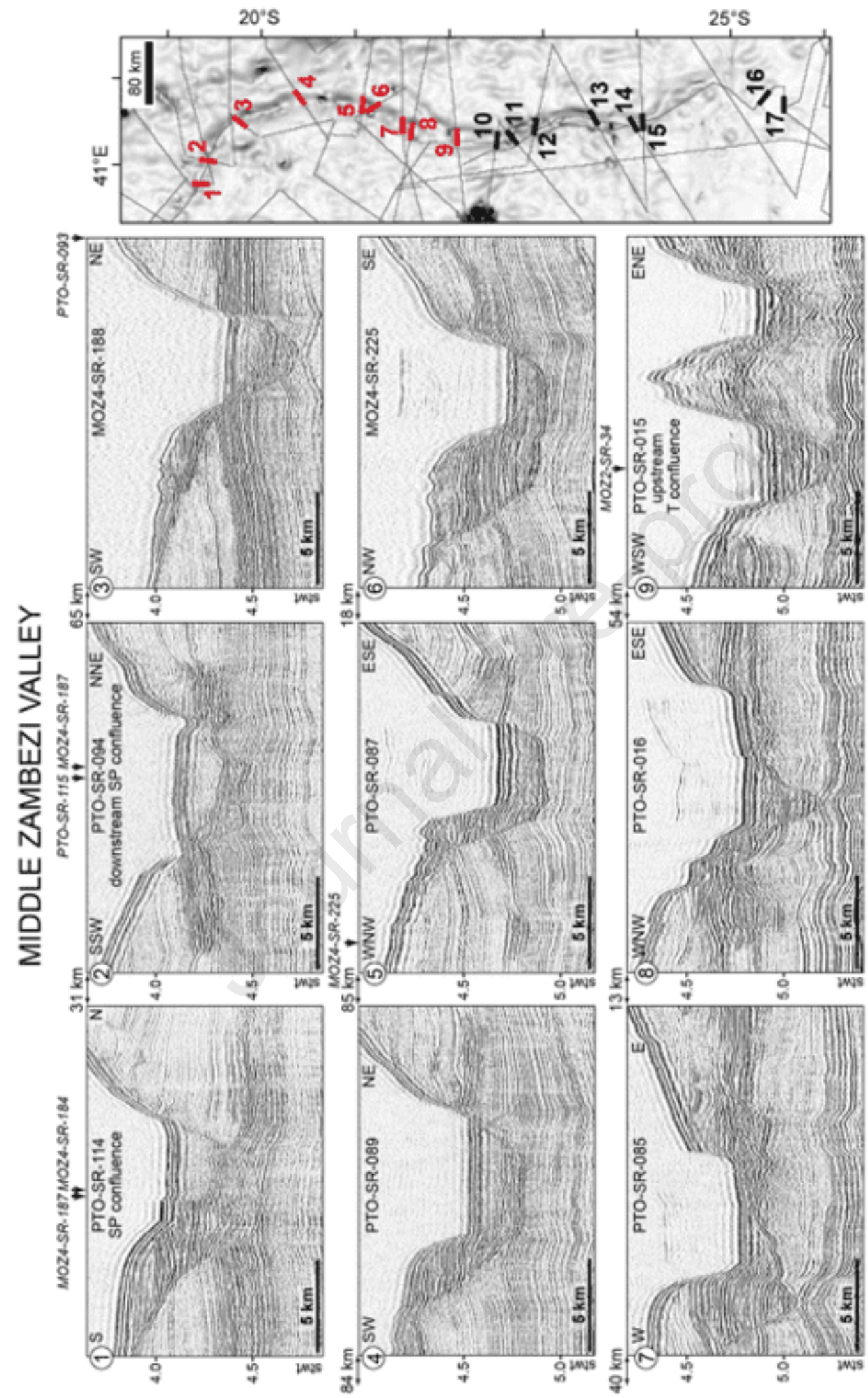

1313 Supplementary material B-1: Uninterpreted seismic profiles of figure 18. 


\section{Supplementary material B-2}
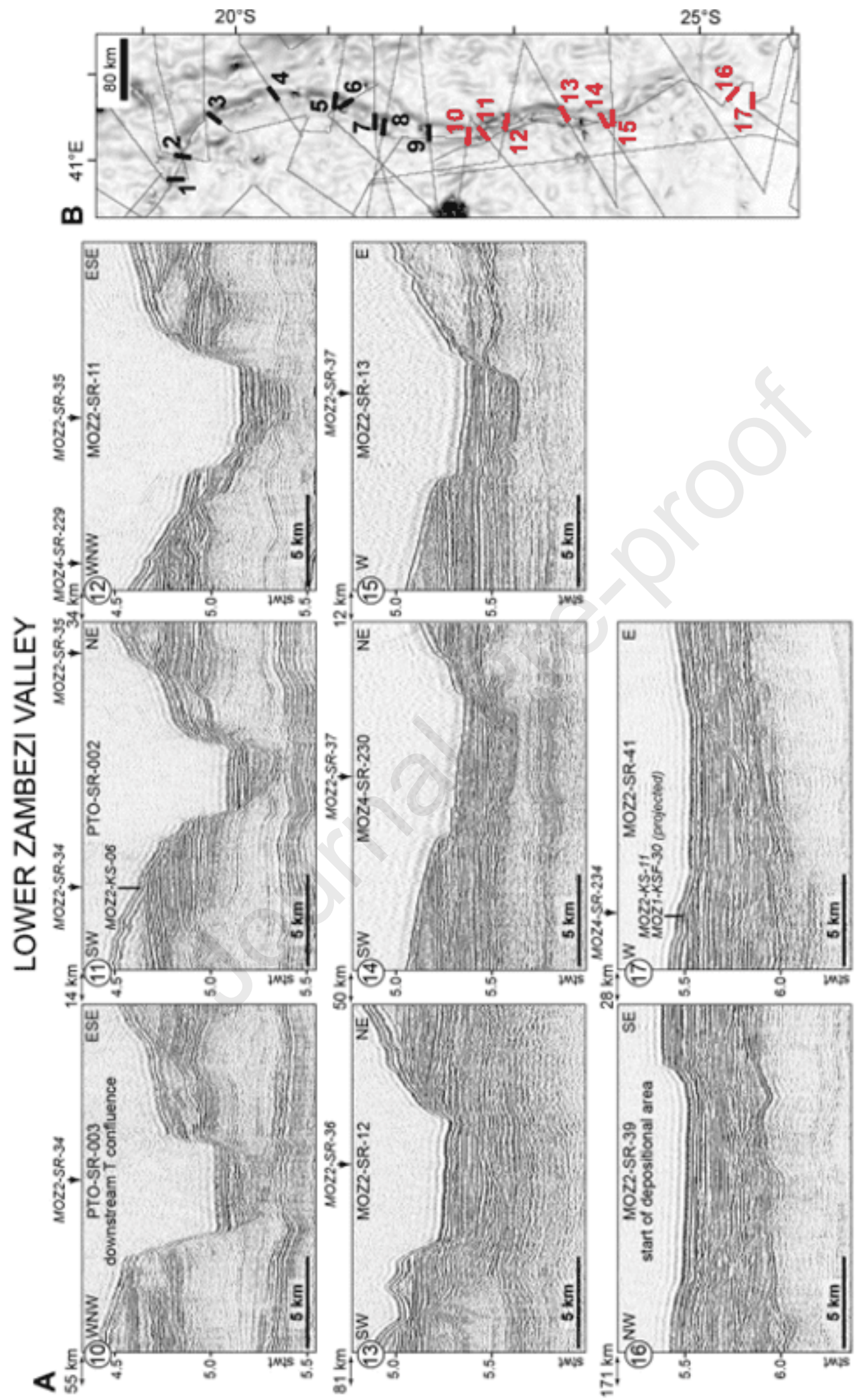

1315

1316

Supplementary material B-2: Uninterpreted seismic profiles of figure 19. 


\section{Highlights}

- High-resolution seismic reflection data is used to investigate the Oligocene to present architectural evolution of the Zambezi depositional system.

- Five major depositional units are identified and demonstrate both turbiditic and contouritic deposits that occur most often synchronously.

- The Zambezi Fan is characterized by various episodes of incision that evidence multiple shifts of feeding axes since Oligocene.

- Progressive structural doming during Late Miocene caused a deep entrenchment of the Zambezi Valley. 


\section{Declaration of interests}

$\bigotimes$ The authors declare that they have no known competing financial interests or personal relationships that could have appeared to influence the work reported in this paper.

$\square$ The authors declare the following financial interests/personal relationships which may be considered as potential competing interests:

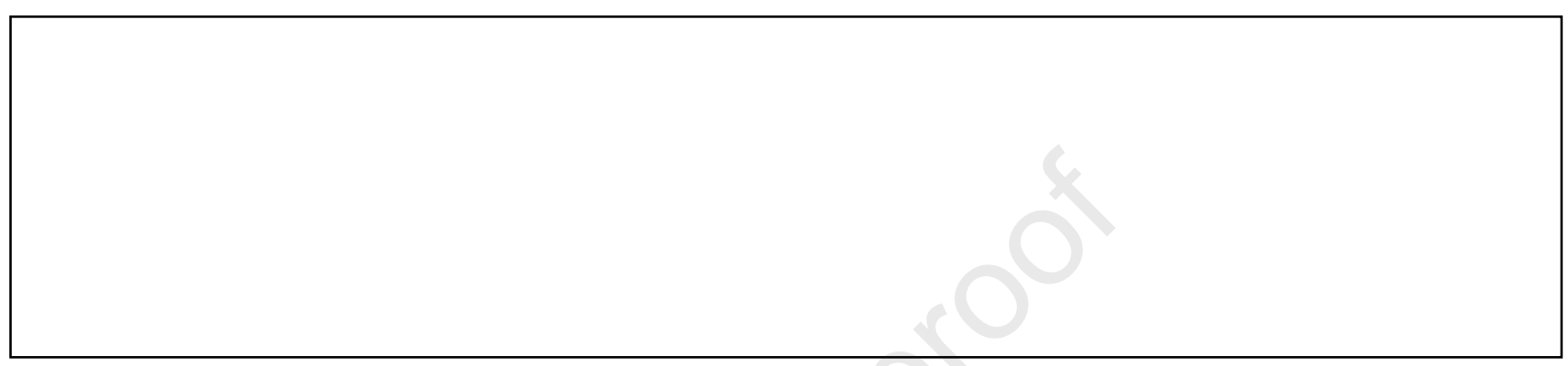

